\title{
Correlation of Wireline Log Characteristics with Hydrothermal Alteration and Other Reservoir Properties of the Salton Sea and Westmorland Geothermal Fields, Imperial Valley, California, USA
}

Frank S. Muramoto*

Wilfred A. Elders* 


\section{DISCLAIMER}

This report was prepared as an account of work sponsored by an agency of the United States Government. Neither the United States Government nor any agency Thereof, nor any of their employees, makes any warranty, express or implied, or assumes any legal liability or responsibility for the accuracy, completeness, or usefulness of any information, apparatus, product, or process disclosed, or represents that its use would not infringe privately owned rights. Reference herein to any specific commercial product, process, or service by trade name, trademark, manufacturer, or otherwise does not necessarily constitute or imply its endorsement, recommendation, or favoring by the United States Government or any agency thereof. The views and opinions of authors expressed herein do not necessarily state or reflect those of the United States Government or any agency thereof. 


\section{DISCLAIMER}

Portions of this document may be illegible in electronic image products. Images are produced from the best available original document. 


\section{DISCLAIMER}

This report was prepared as an account of work sponsored by an agency of the United States Government. Neither the United States Government nor any agency thereof, nor any of their employees, makes any warranty, express or implied, or assumes any legal liability or responsibility for the accuracy, completeness, or usefulness of any information, apparatus, product, or process disclosed, or represents that its use would not infringe privately owned rights. Reference herein to any specific commercial product, process, or service by trade name, trademark, manufacturer, or otherwise does not necessarily constitute or imply its endorsement, recommendation, or favoring by the United States Government or any agency thereof. The views and opinions of authors expressed herein do not necessarily state or reflect those of the United States Government or any agency thereof. 
CONTENTS

Page

ABSTRACT ........................ 1

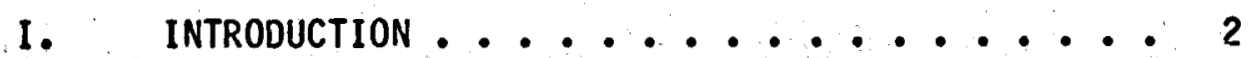

II. GEOLOGICAL BACKGROUND ......... 3

A. Regional Setting ............. 3

B. Drilling History in the Salton Sea and Westmorland Geothermal Areas ...... 5

C. Previous Well Log Work ........ 6

D. Hydrothermal Mineralogy ........ 7

III. COLLECTION AND PROCESSING OF DATA ..... 9

A. Wireline Logs ............ 9

B. Petrologic Data .............. 11

C. Temperature Profiles .......... 12

D. Petrophysical Analyses ......... 12

E. Petrographic Study ........... 12

IV. MINERAL ZONE AND LOG DATA PRESENTATION . . . 12

A. Well Log and Temperature Data vs. Depth •. 12

B. Rsd/Rsh vs. Depth ......... 22

C. Resistivity-Density Crossplot ...... 22

D. N-Resistivity Crossplot ........ 23

v. MINERAL ZONE IDENTIFICATION ON LOGS ..... 24

A. Salton Sea Geothermal System ........ 25

1. Montmorillonite Zone ........ 25

2. Illite Zohe ............25

3. Chlorite Zone .......... 27

4. Feldspar Zone . . . . . . . 29

B. The Westmorland Geothermal Field ..... 30

C. Problems in the Delineation of Mineral

Zones on Logs .......... 32

D. Detection of Igneous Rocks ...... 33 
CONTENTS (cont inued)

Page

VI. USE OF THE EMPIRICAL RELATIONSHIPS TO IDENTIFY

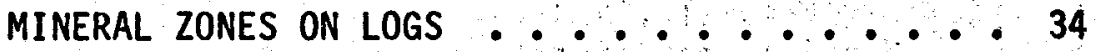

VII. LOG-DERIVED SALINITY ......... 39

A. Application to the Westmorland Wells .... 41

VIII. RESERVOIR POROSITY ........... 43

IX. A COMPARISON BETWEEN THE SALTON SEA AND

CERRO PRIETO GEOTHERMAL FIELDS . . . 51

X. SUMMARY AND CONCLUSION . . . . . . . 52

ACKNOWLEDGMENTS ............. 54

REFERENCES ................ 54

APPENDICES ................. 62

Appendix $1 \ldots \ldots . . . \cdot 63$

Appendix 2 .................. 68

Appendix $3 \ldots \ldots \ldots \ldots 76$

Appendix 4 .............. 83

Appendix 5 ............ 84

Appendix $6 \ldots . . . . . . . . . .65$ 


\section{LIST OF FIGURES}

Figure

Page

1 Location of the Salton Sea, Westmorland, and other geothermal fields in the Imperial Valley and adjacent area of the Salton Trough .... 4

2 Location of the wells chosen for study in the Salton Sea and Westmorland geothermal areas ... 5

3 Well Elmore 1 - Summary of lithologic, temperature, authigenic mineral variation, and sandstone mineral zones ......... 8

4 Well Magmamax 3 - Temperature data ..... 13

5 Well I.I.D. 2 - Temperature data $\ldots \ldots 13$

6 Well Elmore 1 - Temperature data ...... 13

7 Well Sinclair 4 - Temperature data ...... 13

8 Well Britz 3 - Temperature data ....... 14

9 Well River Ranch 1 - Temperature data ..... . 14

10 Well Magmamax 2 - Well log data vs. depth... 15

11. Well Magmamax 3 - Wéll log data vs. depth .... 15

12 Well I.I.D. 2 - Well log data vs, depth . . . 16

13 Well Elmore 1 - Well log data vs. depth.... 16

14 Heli Sinclair 4 - Well log data vs. depth . . . 17

15 Well Sinclair 3 - Well log data vs. depth . . . 17

16 Well Britz 3 - Well log data vs, depth ... 18 


\section{LIST OF FIGURES (continued)}

Figure

Page

17 Well Landers 1 - Well log data vs. depth .... 18

18 Well Kalin Farms 1 - Well log data vs. depth . 19

19 Well Dearborn Farms 1 - Well log data vs. depth 20

20 Well Landers 2 - Well log data ys. depth ... 20

21 Well Magmamax 2 - Resistivity-density crossplot . 22

22 Well Magmamax 3 - Resistivity-density crossplot . 22

23 Well Magmamax 2 - N-Resistivity crossplot ... 23

24 Well Magmamax 3 - N-Resistivity crossplot ... 23

25 A comparison of clay particle orientation for different conditions during sedimentation . . . 26

26 Well Sinclair 4 - Average salinity vs. homogenization temperature of fluid inclusion data . . . 27

27 Well Magmamax 2 - Present static temperature profile plotted against the boiling curves for pure water and for 15 and $25 \mathrm{wt} . \% \mathrm{NaCl}$

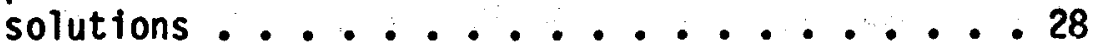

28 Well Magmamax 2 - Example of the high shale resistivities in the feldspar zone ......29

29 Wells Landers 1 and Kalin Farms 1 - Comparison of temperature data ..................

30 Cross section of the Salton Sea geothermal field depicting mineral zones of selected wells ... 32 


\section{LIST OF FIGURES (continued)}

Figure

Page

31 Well Magmamax 3 - Dike rock locations and characteristics ............ 34

32 Well River Ranch 1 - Well log data vs. depth . 35

33 Well Magmamax 1 - Well log data vs. depth ... 36

34 Well Woolsey 1 - Well log data vs. depth . . . 36

35 Well Sinclair 1 - Well log data vs. depth ... 37

36 Well State of Calffornia 1 - Well log data vs. depth ....................... 37

37 Well I.I.D. 1 - Well log data vs. depth . . . 38

38 Well Sportsman 1 - Well log data vs. depth . : 38

39 Well Landers 1 - Log-derived salinity profile . 42

40 Well Landers 2 - Log-derived salinity profile . 42

41 Well Dearborn Farms 1 - Log-derived salinity profile............... 4 42

42 Fence diagram of the formation fluid salinity for selected wells in the Salton Sea and Westmorland geothermal areas .......444

43 Comparison of densities of unaltered and altered shale vs, depth ......... 49

44 Wells Magmamax 2 and 3 - Resistivity-porosity

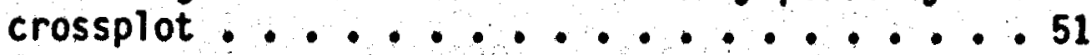

45 Wells Elmore 1 (Salton Sea geothermal system) and T366 (Cerro Prieto geothermal fleld) Resistivity-temperature crossplot ...... 52 


\section{LIST OF SYMBOLS}

Symbol

Definition

a Constant in $F=a_{\psi}-m$ equation

$a_{m f}$ Activity of the mud filtrate

aw Activity of the formation water

DIL - Dual Induction-Laterolog

F Formation resistivity factor

GR Natural gamma ray

IES Induction Electrical Survey

N Neutron porosity divided by density

$R, R_{j l d}$ Resistivity from deep induction $\log$ (ohm-m)

Rilm Resistivity from medium induction $\log$ (ohm-m)

RLL8 Resistivity from laterolog 8 (ohm-m)

$R_{m} \quad$ Resistivity of the mud (ohm-m)

$R_{\mathrm{mf}} \quad$ Resistivity of the mud filtrate (ohm-m)

Ro Resistivity of a non-shaly formation $100 \%$ saturated with brine (ohm-m)

Rsd Resistivity of sandstone from deep induction log (ohm-m)

Rsh Resistivity of shale from deep induction log (ohm-m)

$R_{t} \quad$ True resistivity of formation (ohm-m) 
LIST OF SYMBOLS (continued)

Symbol Definition

RT Resistivity of formation at temperature $T$ (ohm-m)

$R_{W} \quad$ Resistivity of the formation water (ohm-m)

$R_{W T} \quad$ Resistivity of formation water at temperature $T$ (ohm-m)

Rxo Resistivity of invaded zone (ohm-m)

SP Spontaneous Potential (millivolts [mv])

SSP Static Spontaneous Potential (mv)

$T$ Temperature in ${ }^{\circ} \mathrm{F}$

Tc Temperature in ${ }^{\circ} \mathrm{C}$

$\phi \quad$ Porosity measured in laboratory

$\phi_{\text {ch }}$ Porosity calculated from chlorite zone

$\phi_{\mathrm{fl}} \quad$ Porosity calculated from feldspar zone

$\phi_{10 g}$ Porosity calculated from gamma-gamma density

$\phi_{\mathrm{t}} \quad$ True porosity

$\rho_{B} \quad$ Bulk dȩnsity estimated from gamma-gamma density log $\left(\mathrm{gm} / \mathrm{cm}^{3}\right)$

$P_{B L} \quad$ Bulk density estimated from laboratory $\left(\mathrm{gm} / \mathrm{cm}^{3}\right)$

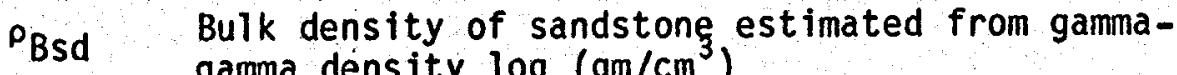
gamma density $\log \left(\mathrm{gm} / \mathrm{cm}^{3}\right)$

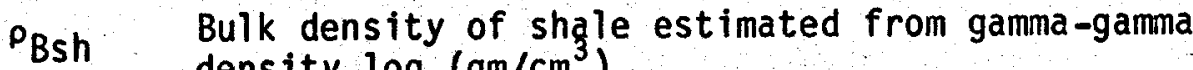
density $\log \left(\mathrm{gm} / \mathrm{cm}^{3}\right)$ 
LIST OF SYMBOLS (continued)

Symbol

$\rho_{f}$

$P_{\text {fT }}$

$\rho \mathrm{gr}$

orch

Pgrfl

$\rho_{\text {the }}$
Definition

Formation fluid density $\left(\mathrm{gm} / \mathrm{cm}^{3}\right)$

True formation fluid density $\left(\mathrm{gm} / \mathrm{cm}^{3}\right)$

Grain density $\left(\mathrm{gm} / \mathrm{cm}^{3}\right)$

Grain density calculated for the chlorite zone $\left(\mathrm{gm} / \mathrm{cm}^{3}\right)$

Grain density calculated for the feldspar zone $\left(\mathrm{gm} / \mathrm{cm}^{3}\right)$

Theoretical bulk density due only to compaction $\left(\mathrm{gm} / \mathrm{cm}^{3}\right)$

$x i \mathbf{i}$ 
CORRELATION OF WIRELINE LOG CHARACTERISTICS WITH HYDROTHERMAL

ALTERATION AND OTHER RESERVOIR PROPERTIES OF THE SALTON SEA

AND WESTMORLAND GEOTHERMAL FIELDS, IMPERIAL VALLEY, CALIFORNIA, USA

by

Frank S. Muramoto and Wilfred A. Elders

ABSTRACT

The Salton Sea and Westmorland geothermal systems are developed in the Plio-Pleistocene sediments of the Colorado River delta. In the Salton Sea, field temperatures as high as $365^{\circ} \mathrm{C}$ are encountered at depths less than $7100 \mathrm{ft}(2134 \mathrm{~m})$, and brines contain up to 260,000 parts per million (ppm) of total dissolved solids. In the Westmorland field four miles $(6.4 \mathrm{~km})$ to the south, considerably lower temperatures $\left(252^{\circ} \mathrm{C}\right.$ at $7500 \mathrm{ft}[2286 \mathrm{~m}]$ ) and less saline brine concentrations (maximum salinity approximating $72,000 \mathrm{ppm}$ ) a re found. A detailed study of wireline logs from 11 wells in the Salton Sea and Westmorland geothermal systems was undertaken in order to determine the effects of hydrothermal alteration on the response of electrical and gamma-gamma density well logs. For the Salton Sea geothermal field, definite correspondence between $\log$ responses and hydrothermal mineralogy is evident, which in turn is related to the physical properties of the rocks. Three hydrothermal and one unaltered zone can be identified from log data on shales. These are: (1) the unaltered "montmorillonite zone" $\left(<100^{\circ}\right.$ $\left.190^{\circ} \mathrm{C}\right)$; (2) the "illite zone" $\left(100^{\circ}-190^{\circ} \mathrm{C}\right.$ to $\left.230^{\circ}-250^{\circ} \mathrm{C}\right)$; (3) the "chlorite zone" $\left(230^{\circ}-250^{\circ} \mathrm{C}\right.$ to $\left.290^{\circ}-300^{\circ} \mathrm{C}\right)$; and (4) the "feldspar zone" $\left(>290^{\circ}-300^{\circ} \mathrm{C}\right)$. The characteristic responses on well logs by which these zones are identified result primarily from changes in clay mineralogy of the shales and increases in density with progressive hydrothermal metamorphism.

In the Westmorland geothermal field, differentiating mineral zones from log responses was only partially successful. However, analyses of both well $\log$ and petrologic data for wells Landers 1 and Kalin Farms 1 suggest that the former is heating up and the latter is cooling. 
Other methods that were found to be effective in delineating mineral zones from log data on shales are the resistivity-density and $N$-resistivity (where $N=$ neutron porosity/density) crossplots. The latter crossplot distinguishes mineral zones better than the former since another variable, neutron porosity, is used. Both crossplots are, however, unsuccessful in differentiating mineral zones in sandstones.

In addition to the 11 we11s, 7 more wells in the Salton Sea geothermal field were studied in order to test the empirical methods developed in this study. It was found that the lack of porosity data inhibited the effectiveness of distinguishing the zones.

Three conditions must be considered in order to interpret log data accurately by the empirical methods in this study. These are a knowledge of the downhole salinity profile, concentrations of resistive minerals in a section of a well, and the presence of thick shale horizons. Gamma-gamma density logs, petrophysical and petrographic data indicate that net induration of the sandstone and shales has occurred in all altered zones. The gammagamma density log was shown to be fairly accurate in recording the true formation density in a hydrothermal environment. Use of Archie's equation to obtain porosity from electric logs was also studied. This method proved unsuccessful in this case, but under different conditions this method may be of value.

Three different methods were used to calculate salinity from wireline logs. The log-derived salinity values are in poor agreement with the actual formation water salinity. Nevertheless, the trend of the log-derived salinity profile may reflect the trend of the true salinity profile.

A comparison of electric log data for the Salton Sea and Cerro Prieto reservoirs indicates that the high salinity in the Salton Sea field $(250,000 \mathrm{mg} / \mathrm{L})$ has lowered the overall resistivity responses in all zones in relation to Cerro Prieto $(18,000 \mathrm{mg} / \mathrm{L})$.

\section{INTRODUCTION}

The analysis of downhole wireline logs plays an integral part in the exploration and development of oil and gas fields. The many years of experience gained in $\log$ analysis of these fields have led to very sophisticated techniques for evaluation of such energy resources. In contrast, well log analysis of geothermal fields has been much more limited due to several factors. These. include the small number of producing fields, the temperature limitations of logging tools, the problems of proprietary data, and logging in nonsedimentary rocks. Recently, however, development of this nonpetroleum energy resource has burgeoned. Therefore, methods such as log interpretation which can aid its development must be more fully investigated. 
Because of the similarity in lithologic characteristics to some oil fields, the Salton Sea and Westmorland geothermal fields offer unique opportunities for well log analysis. Certain techniques employed in formation evaluation of petroleum fields can be used in the Westmorland geothermal field, which has moderate temperatures $\left(252^{\circ} \mathrm{C}\right.$ at $7500 \mathrm{ft}[2286 \mathrm{~m}]$ ) and fluid salinities (maximum concentrations approximating 72,000 parts per million [ppm]). However, the extreme conditions in the Salton sea geothermal field - with temperatures greater than $300^{\circ} \mathrm{C}$ and hypersaline formation fluids approximating $250,000 \mathrm{ppm}$-required refinement and development of new techniques in log analysis.

All wells in these two geothermal fields have been drilled by private energy resource companies. Consequently, all data are proprietary in nature. However, through the cooperation of several of these companies, wireline logs, drill-cutting samples, and other relevant data for some of these wells have been released to Dr. W. A. Elders and the Institute of Geophysics and Planetary Physics at the University of California, Riverside (UCR). Electrical logs have been run in all of the wells that have been studied. Unfortunately, only 1 imited log porosity data were available for use.

The purpose of this study is to identify the effects of hydrothermal alteration on wireline $\log$ response and to determine the degree of alteration, the porosity changes, and temperature effects from logs. Initially, log curves for 11 wells in the Salton Sea and Westmorland geothermal areas were correlated with mineralogic and temperature data generated in this and a previous study (S. D. MCDowe11, unpublished data). Later, seven additional wells in the Salton Sea field were studied to test the methods developed in this study. Laboratory petrophysical measurements were then compared with log-derived salinity values to determine the accuracy of the $10 \mathrm{~g}$ data in the hydrothermal environment. Log-derived salinities were calculated in order to ascertain the effects of salinity on log response. Furthermore, earlier theories on the nature of the reservoir were tested against these log data.

The hope is to provide an alternative means of determining reservoir parameters such as temperature, porosity, salinity, and patterns of hydrothermal alteration, through use of electric and porosity logs rather than the more costly and time-consuming laboratory procedures of geochemistry, hydrology; petrology, and mineralogy.

\section{GEOLOGICAL BACKGROUND}

\section{A. Regional Setting}

The Salton Sea Geothermal System (SSGS) and the Westmorland Geothermal System (WGS) situated approximately 4 miles $(6.4 \mathrm{~km})$ south, are located near the southeastern end of the Salton Sea in the Imperial Valley, California, USA (Figure 1). This valley is part of the physiographic province known as the Salton Trough, the sediment-filled landward extension of the Gulf of California (Elders et al., 1972; Elders, 1979; Muffler and White, 1969).

The Salton Trough is a complex rift valley that is bordered by steep, stepfaulted mountains of granitic and metasedimentary rocks of Mesozoic age and older (Dibblee, 1954); it also has a relatively flat basement (Elders et al.; 1972; Elders, 1979). The Trough is postulated to have formed by spreading of the oceanic crust to the south and continental crust to the north at a rate of $6 \mathrm{~cm} / \mathrm{yr}$ (Elders et al., 1972; Menard and Atwater, 1970). These spreading centers or "pull apart basins" are offset by a series of right lateral en echelon transform faults of the San Andreas fault system (Elders et al .., 1972; 


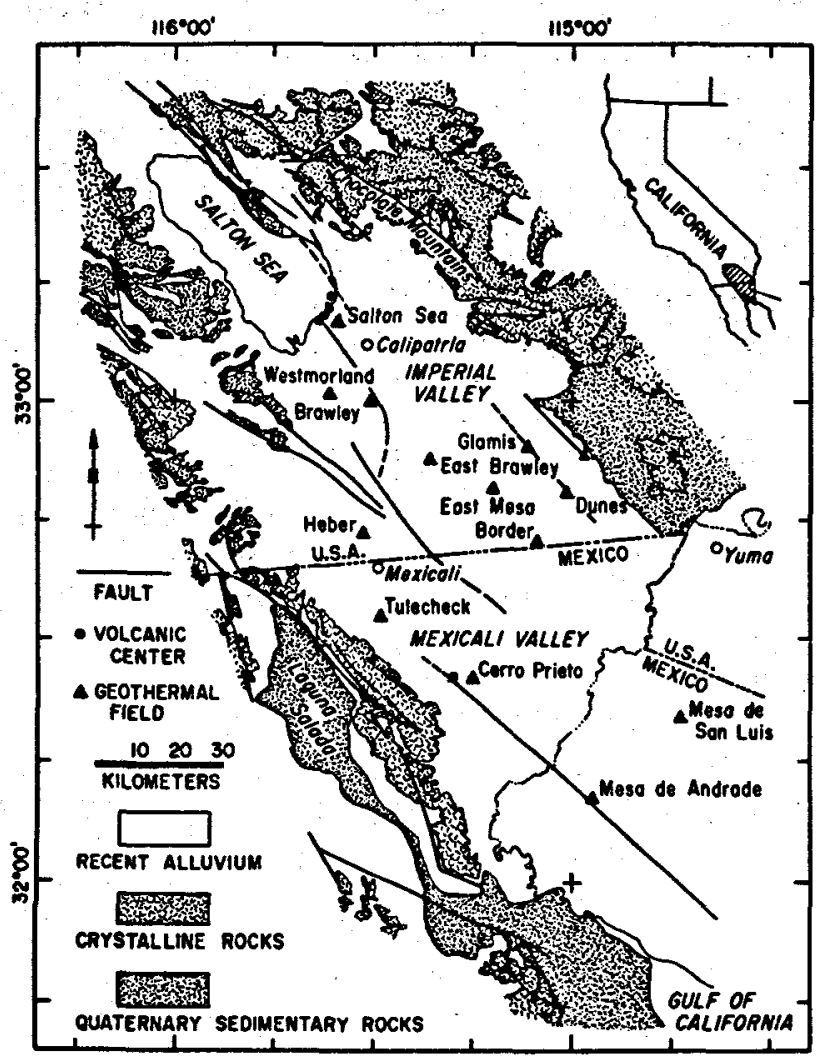

Figure 1. Location of the Salton Sea, Westmorland, and other geothermal fields in the Imperial Valley and adjacent area of the Salton Trough.
Elders and Biehler, 1975). Elders and Biehler (1975) have termed this system as a leaky transform fault.

Presently, the hot geothermal areas in the Imperial and Mexicali Valleys may be a reflection of these spreading centers (Elders et al., 1972). These areas are characterized by high heat flow (von Herzen, 1963; Lee and Cohen, 1979; Rex, 1966; Lawver and Williams, 1979) and microseismicity (Johnson and Hadley, 1976; Gilpin and Lee, 1978; Albores et al ., 1979; Hill et al., 1975), gravity anomalies (Biehler, 1964; 1971; Chase et al., 1979), recent volcanism (Robinson et al ., 1976), and surface hydrothermal manifestations.

The sediments that have accumulated in the Trough consist primarily of deltaic and lacustrine deposits forming part of the Colorado River Delta (van de Kamp, 1973). In these sediments, a decrease in volume percent of sand bodies and grain size occurs with increased distance from the apex of the delta (Randall, 1974; van de Kamp, 1973). Consequently, in the distal portions of the delta, lacustrine muds, silts, and beach sands predominate in contrast to the meandering deltaic channel deposits typically near the apex (van de Kamp,

1973). In the SSGS the overall volume percent of lithologic types based on dril1 cuttings are $70 \%$ shales, $5 \%$ siltstone, and $25 \%$ sandstone (Kenda11, 1976). The progradation of the Colorado River Delta normal to the Trough since the midPleistocene (van de Kamp, 1973) has isolated the Salton Basin from the Gulf of California.

The sandstones and shales in the SSGS have undergone extensive hydrothermal alteration to the greenschist facies by temperatures ranging to $365^{\circ} \mathrm{C}$ at $7117 \mathrm{ft}$ $(2170 \mathrm{~m})$ (Muffler and White, 1969; Elders, 1979; McDowell and Elders, 1979). Highly saline brines of concentrations up to $260,000 \mathrm{ppm}$ have also been encountered (Muffler and White, 1969; Helgeson, 1968). Stratigraphically, this geothermal field can be divided into two sections: (1) an upper unconsolidated to poorly consolidated,clay-silt-evaporite lacustrine sequence and (2) a lower moderately to well-consolidated, interbedded sandstone-siltstone-mudstone deltaic sequence (Randal1, 1974). The lacustrine sequence acts as an impermeable "caprock" over the interbedded deltaic sediments which constitute the reservoir rocks in this system. At present, the oldest sediments reached by drilling are apparently Pleistocene fluviatile and lacustrine deposits (Merriam and Bandy, 1965; Muffler and Doe, 1965).

Recently, McDowell and Elders $(1979,1980)$ have defined three textural prograde metamorphic zones in the deltaic sediments of the SSGS. Based on petrographic and $x$-ray examination of sandstone cuttings, these zones with 
increasing depth and temperature are: (1) the carbonate cap; (2) the porous or reservoir zone; and (3) the hornfels zone. The carbonate cap zone is characterized by high weight percent ( $>30 \mathrm{wt} . \%)$ of carbonate cement, floating grain contacts, and low porosity as estimated in thin section. The transition into the porous zone is marked by an abrupt increase in porosity to $15-20 \%$ and an increase in mutual contacts of detrital quartz and feldspar grains as overgrowths. With increasing depth, the porosity decreases by formation and enlargement of overgrowths on quartz and feldspar grains. The hornfels zone is reached when all visible traces of overgrowths have been removed by recrystallization, producing a dense rock with interlocking granoblastic texture.

Extensive petrologic and geochemical studies have been made recently in the SSGS (Younker et al ., 1982 [review paper]; MCDowell and Elders, 1982, 1980a, 1980b; McDowe 11, 1978; McKibben, 1979; Freckman, 1978; Bird and Norton, 1981; 0lson, 1978). Numerous geological and geophysical investigations have also been carried out (Younker et al., 1982 [review paper]); Humphreys, 1978; Meidav and Howard, 1979; Sigurdson et al., 1971; Biehler, 1964).

In contrast, the Westmorland geothermal area, separated from the SSGS by the Brawley fault (Figure 1) and within its own residual gravity anomaly, shows considerably lower temperatures $\left(252^{\circ} \mathrm{C}\right.$ at $\left.7500 \mathrm{ft}[2286 \mathrm{~m}]\right)$ and less saline brine concentrations (maximum salinity about 72,000 ppm). Hence, less hydrothermal alteration is suggested in the WGS. Olson and Matlick (1978) have studied the geochemical aspects of this field.

B. Drilling History in the Salton Sea and Westmorland Geothermal Areas

In 1927 three wells were drilled by the Pioneer Development Company on Mullet Island to find natural steam (Wynn, 1975) (Figure 2). These wells, the deepest of which was $1473 \mathrm{ft}(449 \mathrm{~m})$, encountered steam, hot water, and noncondensible gases; however, the pressure and volume of steam were considered insufficient for commercial production. Consequently, these wells were abandoned (Rook and Williams, 1942).

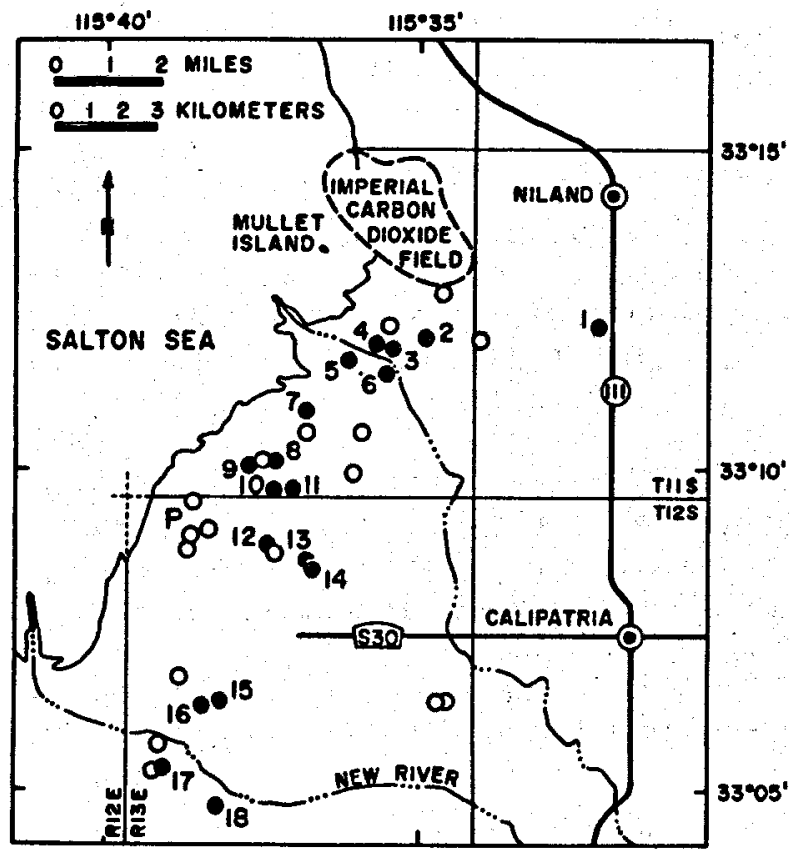

Figure 2. Location of the wells chosen for study in the Salton Sea and Westmor1 and geothermal areas (after Geothermal Resources Counct1, 1981, Geothermal map of the Imperial County, California). - Geothermal wells studied in this report. - Other geothermal wells (not studied in this report).

$1=$ Britz \#3;2 = River Ranch \#1; $3=$ Sportsman \#1; $4=1.1 . D \# 1 ; 5=1.1 . D$. $\# 2 ; 6=$ State of California \#1; $7=\mathrm{El}$ more $\# 1 ; 8=$ Magmamax \#3;9 = Magmamax $\# 2 ; 10=$ Magmamax \#1; 11 = Woolsey \#1; 12 = Sinclair \#4; $13=$ Sinclair \#1; $14=$ Sinclair \#3; $15=$ Landers \#1; $16=$ Landers $\# 2 ; 17$ = Dearborn Farms; $18=$ Kal in Farms. 
The abundance of carbon dioxide gas found in these first wells led to renewed interest in drilling. Then in 1932 the Imperial Carbon Dioxide Field was discovered. This field was commercially developed from 1933-1954 (Rook and Williams, 1942) producing, over 2.5 billion $\mathrm{ft}^{3}$ of $\mathrm{CO}_{2}$ gas (McNitt, 1963) from shallow sands 200 to $700 \mathrm{ft}$ deep. Inundation of many wells by the Salton Sea, depletion of production, and development of modern refrigerated transport led to the abandonment of this field (McNitt, 1963).

The Kent Imperial Corporation "Sinclair 1", sec. 10, T12S, R13E, was the first well in the Imperial Valley to produce substantial amounts of steam. Drilled from late 1957 to early 1958 to $4725 \mathrm{ft}(1440 \mathrm{~m})$, this well is generally considered to be the discovery well for the SSGS (Lande, 1979). From 1961-1964, 11 more wells were drilled with 8 being completed as steam producers.

A hiatus in drilling occurred between 1965-1971. Since 1972, 22 wells have been drilled. To date a total of 41 wells have been completed. Seven of the wells have been abandoned. Six are injection wells, and one is an observation well (California Division of $0 i 1$ and Gas, 1981).

In the Westmorland area, all of the wells have been drilled since 1972. A total of seven wells have been completed; four as production wells, two as reinjection wells, and one is abandoned (see Appendix 1 for a-complete summary).

C. Previous Well Log Work

Although well log analysis in hydrocarbon reservoirs is highly advanced, geothermal well log interpretation is in a developmental stage. Advancement in use and proper analysis of geothermal well logs requires solutions of problems due to high reservoir temperatures and corrosive brines. These problems may cause both tool breakdown and calibration difficulties (Sanyal et al., 1980). At present, however, high-temperature resistant well tools and calibration pits for calibrating well tools in various fractured and unfractured igneous and metamorphic rocks (Mathews, 1980) are being built.

Applegate and Moens (1980), Keys and Sullivan (1980), Rigby and Zebal (1981), O'Sullivan (1979), and Benoit et al. (1981) have studied well logs from nonsedimentary geothermal systems. These studies were able to distinguish empirically different types of igneous and metamorphic rocks and their altered equivalents by inspection and crossplotting of various log data.

Methods used in well log analysis of petroleum fields have been applied to sedimentary geothermal fields. Randall (1974) and Miller. (1980) used electrical logs for parastratigraphic analysis of the SSGS and East Mesa geothermal field, respectively (Figure 1). Ershaghi et al. (1979), using oil field formation evaluation techniques, estimated the formation factor and water resistivity in the Cerro Prieto geothermal field by analyzing electric logs. Littleton and Burnett $(1975,1977)$ used the spontaneous potential (SP) and dual induction logs to calculate the downhole salinity profiles for ten welis in the East Mesa geothermal field. They found that their computed salinities agreed fairly well with those from chemical analyses of the well fluid. However, the high temperatures encountered in deeper portions of these geothermal reservoirs cause hydrothermal metamorphism and the sediments lose their clastic texture. Thus, traditional oil-field log interpretation techniques become difficult to apply to hydrothermally altered sediments.

Other problems to overcome are the effects of cooling agents on log parameters and the large temperature gradients between the borehole annulus and the formation. For example, cooling agents such as dry ice are commoniy dumped into boreholes in order to prevent tool failure due to high temperatures. These agents may cause mud salinity stratification and can alter the SP curve to a significant degree (Ershaghi et al., 1978). Also, large errors in resistivity 
readings may occur because of large temperature gradients between the borehole annulus and the formation. Davis and Sanyal (1979) state that for low-waterloss drilling mud the effect of temperature gradients below $100^{\circ} \mathrm{C}$ on estimations of true formation resistivity is probably minimal.

In a comprehensive well $10 \mathrm{~g}$ study of the Cerro Prieto geothermal field, Seamount (1981) demonstrated that shale log data show good correlation with four mineralogic zones determined by $x$-ray diffraction. These are defined as:

(1) the montmorillonite zone $\left(<150^{\circ} \mathrm{C}\right)$; (2) the illite zone $\left(150^{\circ} \mathrm{C}\right.$ to $\left.230-245^{\circ} \mathrm{C}\right)$; (3) the chlorite zone $\left(230-245^{\circ} \mathrm{C}\right.$ to $\left.300^{\circ} \mathrm{C}\right)$; and (4) the feldspar zone $\left(>300^{\circ} \mathrm{C}\right)$. He could also recognize these zones on electrical logs by noting the parallelism, convergence, or divergence of the respective curves of sand and shale resistivity. He also found that by crossplotting shale resistivity and density dota the mineral zones could be easily identified. Furthermore, his analysis of well logs supports the ideas of fluid flow in the Cerro Prieto reservoir (Seamount and Elders, 1981) developed on the basis of other data.

Previous interpretation of well logs performed in the SSGS dealt mainly with stratigraphic correlation and structure determinations (Randall, 1974; Tewhey, 1977; Chan and Tewhey, 1977). Using SP and resistivity logs combined with the study of well cuttings, Randall (1974) determined that the upper portion of the sedimentary section consists of a wedge-shaped, northward-thickening series of lacustrine clays, silts, and evaporites, while the lower portion consists of intercolated sandstones and shales with a few meters of altered darkbrown rhyolite. Using electric logs, he determined the depth to the top of what he termed the metamorphic zone. By correlation of electric logs between wells, he hypothesized the presence of numerous strike-slip faults to explain the variation in depth of correlatable horizons. From his study of temperature logs, Randall suggested that the geothermal anomaly is not influenced by stratigraphic or structural boundaries. Furthermore, he also proposed that the present shape and size of the Salton Sea reservoir are determined by the distance from a magma intrusion which he supposed caused the anomaly.

Tewhey (1977), on the basis of log correlation and drill-cutting examination, recognized three zones: the upper zone, defined as the caprock which consists of unconsolidated silt, sand, and gravel; the unaltered reservoir zone composed of well-indurated shales, siltstones, and sandstones consisting of dense quartz and feldspar grains cemented with calcite and/or silica; and the lower zone, a hydrothermally altered zone marked by the presence of epidote, which replaced calcite. Later well log correlation suggested that the subsurface structure of the Salton Sea is a structural basin whose axis trends northwest (Chan and Tewhey, 1977).

D. Hydrothermal Mineralogy

The sediments in the SSGS have undergone various degrees of hydrothermal metamorphism with depth caused by high temperatures and hypersal ine brines. Greenschist facies metamorphism of these sediments is presently occurring (Muffler and White, 1969; McDowell and Elders, 1979, 1980a, 1980b, 1982). Previous studies of hydrothermal alteration in volcanic and sedimentary geothermal fields have shown that there is a correspondence between certain metamorphic mineral assemblages and temperatures (Browne, 1978 [review paper]; McDowell and Elders, 1979, 1980a). In the SSGS, detailed mineralogic studies have been carried out at UCR (MCDowell and Elders, 1979, 1980a, 1982; Kendall, 1976; Mckibben, 1979). Figure 3 shows the authigenic mineral assemblages in sandstones for the representative borehole Elmore 1, located near the center of the SSGS (MCDowell and MCCurry, 1978). When the same authigenic mineral occurs in the sandstones and shales, the mineral appears at a shallower depth and lower 


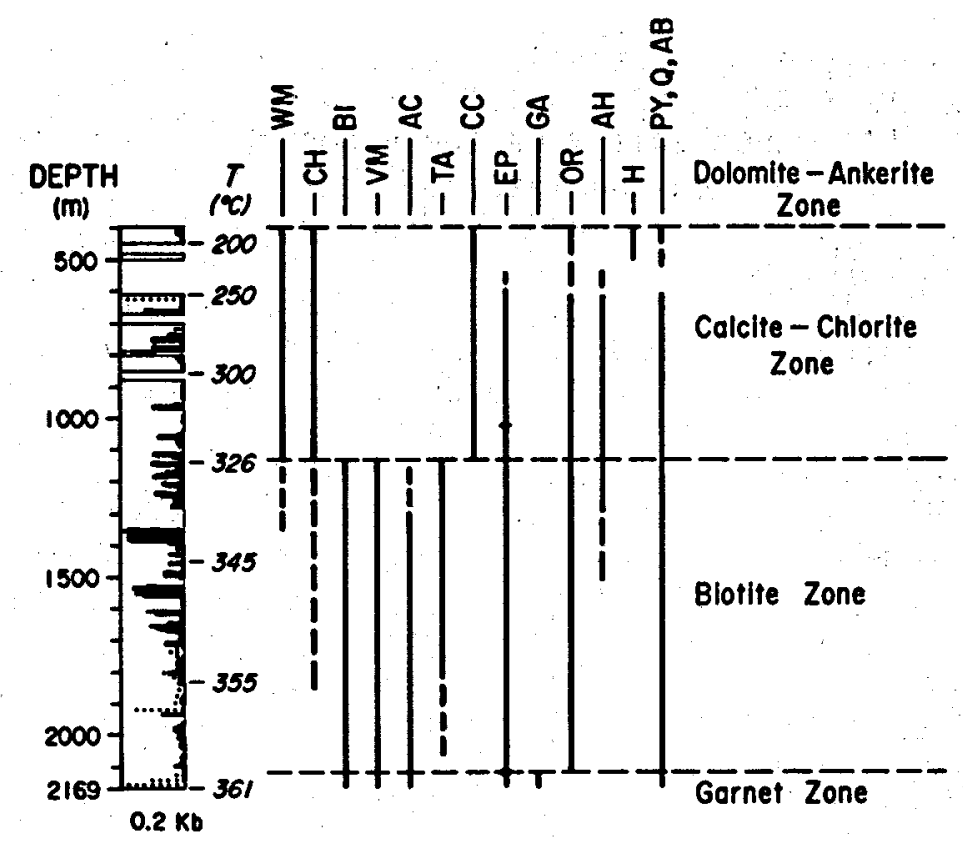

Figure 3. Summary of lithologic, temperature, authigenic mineral variation, and sandstone mineral zones in well Elmore 1. In the lithologic column, clear = shale; solid black = sand; and dots = volcanic material. Temperature from Helgeson (1968). Vertical bars show depth range of authigenic minerals in sandstones: solid where common, dashed where sporadic and in minor quantities. Horizontal lines separate the major metamorphic zones: dolomite/ankerite from <1440 ft $(439 \mathrm{~m})$; the calcite/chiorite from $1440-3723 \mathrm{ft}$ (439-1135 m); biotite from $3723-6954 \mathrm{ft}(1135-2120 \mathrm{~m}) ;$ garnet from $>6954 \mathrm{ft}(2155 \mathrm{~m}) . W M=$ illite and white mica; $\mathrm{CH}=$ chlorite; $\mathrm{BI}=$ biotite; $\mathrm{VM}=$ vermiculite in rare clay fraction; $A C=$ actinolite; $T A=$ tal $C ; C C=$ calcite; $E P=$ epidote $; G A=$ garnet; $O R=$ orthoclase/microcline; $A H=$ Anhydrite; $H=$ hematite (and dolomite); $P Y=$ pyrite; $Q=$ quartz; $A B=$ albite (after McDoweil and McCurry, 1978).

temperature in sandstones. Higher original permeability for the sandstones probably causes this difference (McDowell and Elders, 1979; Elders et al.., 1979). In this study the mineralogic zones are based on shale x-ray diffraction data since shale mineralogy has a greater effect on resistivity and gamma-gamma density than does the mineralogy of sandstones, as will be shown later. The term "shale" is used here to designate mudstones and other claystones, rather than implying that the rocks have the fissility of true shales. X-ray diffraction data for the shales are included in Appendix 2.

The montmorillonite zone, the coldest of the defined shale mineral zones, is characterized by the presence of the clays, montmorillonite, and kaolinite. Depending upon the location of the wells in the SSGS, this shale zone is correlative with the lacustrine sequence of Randall (1974) or part of the dolomite/ ankerite zone in the sandstones (McDowell and Elders, 1980a). The sediments are mostly unconsolidated in this zone.

The calcite-chlorite zone in the sandstones as defined by McDowell and Elders (1980a) occurs at temperatures of $190^{\circ} \mathrm{C}-325^{\circ} \mathrm{C}$. They have observed the following major changes in the constitution of the layered silicates 
in sandstones in this zone. Between $190^{\circ} \mathrm{C}-275^{\circ} \mathrm{C}$ the 111 ite/smectite consists of $0-5 \%$ expandable layers. At $300^{\circ} \mathrm{C}$ significant recrystallization of most layer silicates occurs. Throughout this zone the sandstone and shale clay size fraction becomes more chlorite rich and less abundant (McDowell and Elders, 1980a). Also at approximately $300^{\circ} \mathrm{G}$ quartz and feldspar are recrystallized to produce hornfelsic-textured sandstones.

In this study at temperatures corresponding to the calcite-chlorite and to the lower portion of the dolomite/ankerite zones in sandstones, three different shale zones have been defined. These are here termed the illite, chlorite, and feldspar zones.

The illite zone occurs in shales at temperatures from $100^{\circ} \mathrm{C}-190^{\circ} \mathrm{C}$ to $230^{\circ} \mathrm{C}-250^{\circ} \mathrm{C}$. The percentage of 111 ite increases from approximately $13-15 \%$ to $20 \%$ in this zone; however, montmorillonite is absent. The chlorite zone occurs in shales at $230^{\circ} \mathrm{C}-250^{\circ} \mathrm{C}$ to $290^{\circ} \mathrm{C}-300^{\circ} \mathrm{C}$. A rapid increase in the percentage of chlorite from approximately $9 \%$ to $13 \%$ characterizes the lower temperature boundary of this zone. Dolomite and kaolinite are mostly absent, and the illite continues to increase to $30 \%$ or more throughout this zone. By $300^{\circ} \mathrm{C}$ the interlayered montmorillonite has usually disappeared.

The feldspar zone occurs above $300^{\circ} \mathrm{C}$ in shales. A large increase in plagioclase and alkali feldspar is the distinctive mineralogic change. This increase, often greater than $20 \%$, is at the expense of the layered silicates (Appendix 2). Illite decreases in this zone, and calcite is typically absent. The hottest zone in the shales, defined as the biotite/calc-aluminum silicate zone, occurs where biotite, amphibole, and epidote are initially detected by $x$-ray diffraction. Only three wells in this study have penetrated this zone. Because of the sparse $x$-ray data in this zone, an exact temperature range cannot be given. The lack of data precludes detailed interpretation; therefore, this zone will not be mentioned further.

\section{COLLECTION AND PROCESSING OF DATA}

Logs for the 18 wells examined in this study were made available to UCR by Randall (1974) and Republic Geothermal, Inc. (Table 1). In the SSGS, the criteria used in the selection of seven wells for detailed study were the completeness of well log data and the amount of petrologic and temperature data al ready avallable. In addition, these wells were chosen from different areas within the field in order to estabiish analytical methods for the entire field. Because of the lack of complete well log suites in the other wells of the SSGS, the authors extended the study. into the Westmorland area where more complete well log suites were available. Four wells were analyzed in the WGS. Furthermore, a reconnaissance log study of seven additional wells in the SSGS was undertaken to test the empirical methods presented in this report (see pages 34-39). Figure 2 shows the location of all wells studied. Table 1 lists the 18 wells and the data used.

\section{A. Wireline Logs}

Electric logs were primarily used in this study. Where avallable, gammagamma density, neutron, and sonic logs were also scrutinized. A summary of the basic principles of these logs types is presented in various log manuals (Schl umberger, 1972; Dresser Atlas, 1974) and in Seamount (1981). Nearly complete electric log coverage was obtained for all wells studied except for Britz 3, Sinclair 3 and 4 . These wells, however, do have electric log coverage 
Wirel ine Log, Minerałogic, and Temperature Data Used in this Study

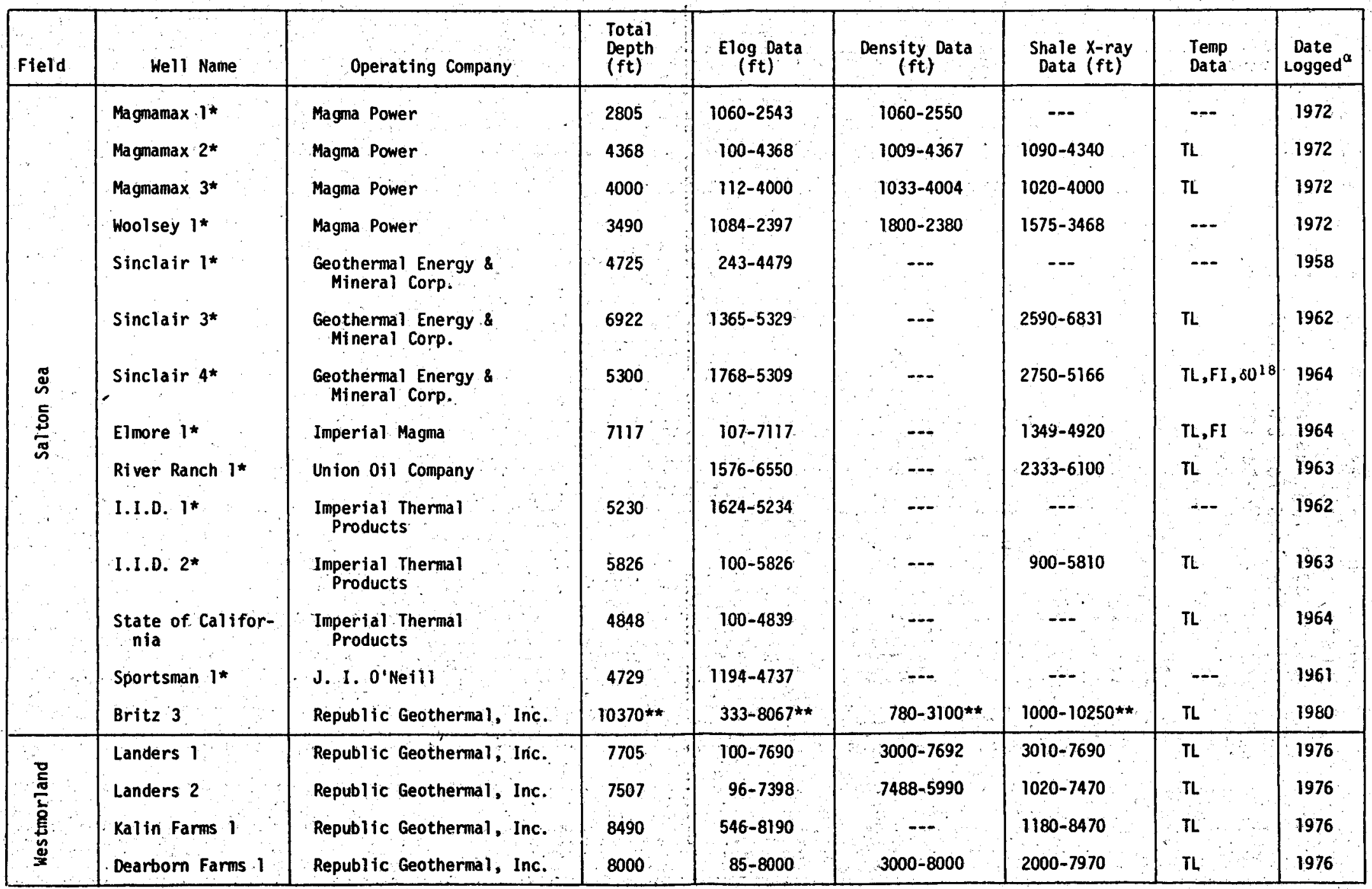


over intervals important to this study. Only five wells have usable and sufficient gamma-gamma density log data.

Careful inspection of each $\mathrm{log}$ was undertaken to determine its quality. For the newer logs, e.g., the logs for the Republic wells, several repeat runs were available for examination. These logs we re deemed of acceptable quality (Table 1). The older logs do not have appended repeat runs. These logs, however, were assumed to be of acceptable quality. As will be shown later (pages 12-18), this assumption could be proved valid in certain cases as similar trends in log data were observed on older logs as on newer logs.

Additional criteria were employed to select log values presented since most are uncorrected for borehole size and mud temperature. The log values were al ways picked from lithologic units at least $5 \mathrm{ft}(1.52 \mathrm{~m})$ thick and preferably greater than $10 \mathrm{ft}(3 \mathrm{~m})$ in order to el iminate errors due to bedding contacts (schlumberger, 1972). Next, since oversized boreholes particularly affect gamma-gamma density values (Maxant, 1980), data were not generally used from boreholes greater than 15\% oversized. However, in order to facilitate greater use of these data, in particular with the gamma-gamma density, compensation curves were applied to correct for oversized hole diameters but only for boreholes $>15-20 \%$ oversized. In addition, the gamma-gamma density values that are corrected by compensation curves were constrained by not allowing the density values to be corrected to vary more than $0.1 \mathrm{gm} / \mathrm{cm}^{3}$ from those values $100 \mathrm{ft}$ $(30.5 \mathrm{~m})$ above and $200 \mathrm{ft}(61 \mathrm{~m})$ below (C. Isselhardt, personal communication, 1981). These constraints on $\log$ density values were effective, as shown by close agreement between $\rho_{B}$ and petrophysical data (see pages 46-49).

Sand and shale log values were hand picked independently over $50 \mathrm{ft}$ (15 m) intervals and then plotted at a reduced scale of $500 \mathrm{ft} / \mathrm{in}$.

Sands and shales were distinguished on the basis of self potential (SP) deflections. Gamma-ray $\log$ readings were also used as a check of lithologic type. Usually low gamma-ray counts and SP deflections to the left indicate sands. Within a given interval, log values were picked opposite maximum and minimum SP and gamma-ray deflections.

After handplotting the data, the curves were machine digitized (although some were hand digitized due to machine breakdown) and run through computer programs which produced most of the figures presented.

B. Petrologic Data

Hydrothermally altered sediments are present in all of the wells studied (McDowe11 and Elders, 1979, 1980a, 1980b, 1982; Muffler and White, 1969; Kenda11, 1976; Freckman, 1978; 01 son and Matlick, 1978). The zones of mineral alteration are based exclusively on $x$-ray diffraction data of cutting samples. The mineralogy of shales affects the $\log$ responses to the greatest degree; therefore, the zones defined above are based exclusively on shale mineralogy (Appendix 2). Sand mineralogy will be referred to as needed (Appendix 3 ). Problems in contamination of drill cuttings and determination of depth resulting from lag time have been described by Miller (1980), Hoagland (1976), and Kendall (1976). The sampling interval for the $x$-ray analyses in most well s is approximately $250 \mathrm{ft}(76.3 \mathrm{~m})$.

X-ray diffraction data for eight wells were generated in this study (see Appendices 2 and 3 ). For the $x$-ray diffraction analyses of shales, representative buik samples were picked so that biasing the $x$-ray determined bulk mineralogy by selection of one predominate shale color was eliminated. Three different colors of shales are present in the SSGS and WGS. These are red brown in the upper portions, light gray at intermediate depths, and dark gray near the bottom of the wells. These color zones are transitional and do not appear to 
correlate with the previously defined mineral zones in shales. The data for the remaining wells were produced from a previous study (McDowell, unpublished data, Appendix 2).

C. Temperature Profiles

Due to borehole conditions, such as cooling effects of drilling fluids and later heating of upper strata through production, measured temperatures within a well do not always reflect the true formation or reservoir temperature. Under certain conditions, however, measured temperatures may be near formation temperatures. Among these conditions are that the mud should be washed out of the well after the cessation of drilling and that it should be idle preferably for a period as. long as drilling operations existed.

The temperature logs (Figures $4-9,26,28$ ) presented in this study were chosen as the best representative in situ temperatures (Randa11, 1974, Figures $4,6,7,9,26$; Hel geson, 1968 , Figures $5,6,9)$. In addition, fluid inclusion and oxygen isotopic temperatures are included where available.

D. Petrophysical Analyses

Core samples from well s Landers 1, Dearborn Farms 1, and Kal in Farms 1 were analyzed for porosity using a Ruska mercury porometer and Beckman pycnometer in order to compare the results with $\rho_{B}$ (see pages 43-49).

E. Petrographic Study

Thin sections were examined for well Britz 3 to achieve familiarity with types of rock alteration and porosity that are commonly found. A preliminary petrographic description for Britz 3 is given in Appendix 4.

\section{MINERAL ZONE AND LOG DATA PRESENTATION}

This report employs four types of data displays to demonstrate the effects of hydrothermal alteration and temperature on well log data. These are:

1. Well $\log$ and temperature data vs. depth.

2. Rsd/Rsh vs. depth.

3. $R$ vs. $\rho_{B}$ crossplot.

4. $R$ vs. $N$ crossplot.

All four methods readily differentiate in shales the four mineral zones defined in this report. Each method will be discussed and explained separately. The well $\log$ and Rsd/Rsh vs. depth show both sandstone and shale data together. Log data for only one lithology are shown on individual crossplots. As shall be shown later, data presentations which display log data for the two lithologies together distinguish the mineral zones best.

\section{A. Well Log and Temperature Data vs. Depth}

The mineral zones are plotted on downhole temperature logs in Figures 4-9 and plotted with other well $\log$ data versus depth in Figures 10-20. The depths of the various mineral zones are based on shale $x$-ray diffraction data. (Appendix 2).

Well log data versus depth diagrams exhibit the effect of hydrothermal alteration on the sandstones and shales. This effect is shown by: (1) the virtual parallelism of the sandstone and shale curves within certain zones; and (2) the divergence of the curves in other mineral zones. Table 2 and the following discussion summarize the typical log responses in the SSGS: 


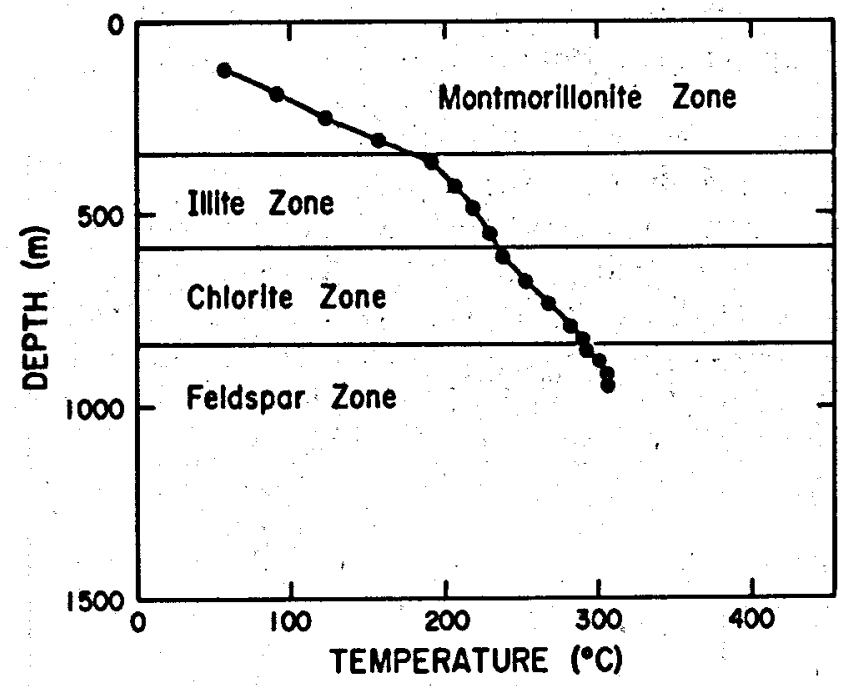

Figure 4. Temperature data for well Magmamax 3, after Randall (1974). Mineral zones in shales are based on this study.

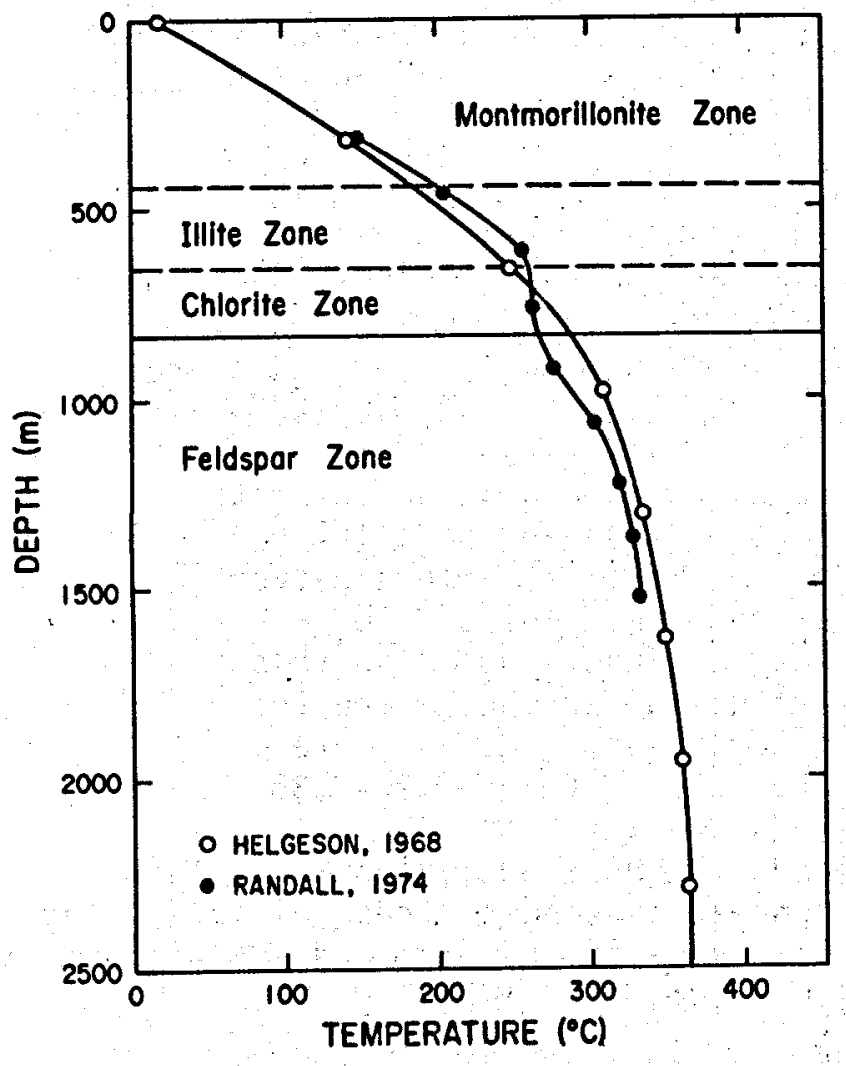

Figure 6. Temperature data for well Elmore 1, after Randall (1974).

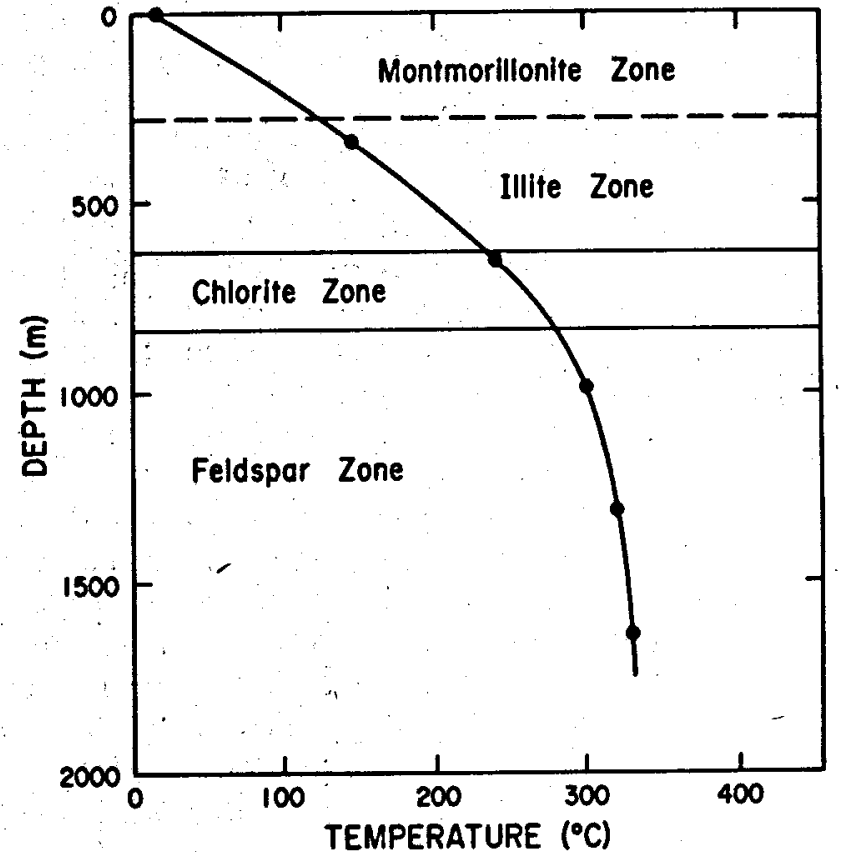

Figure 5. Temperature data for well I.I.D. 2, after Helgeson (1968).

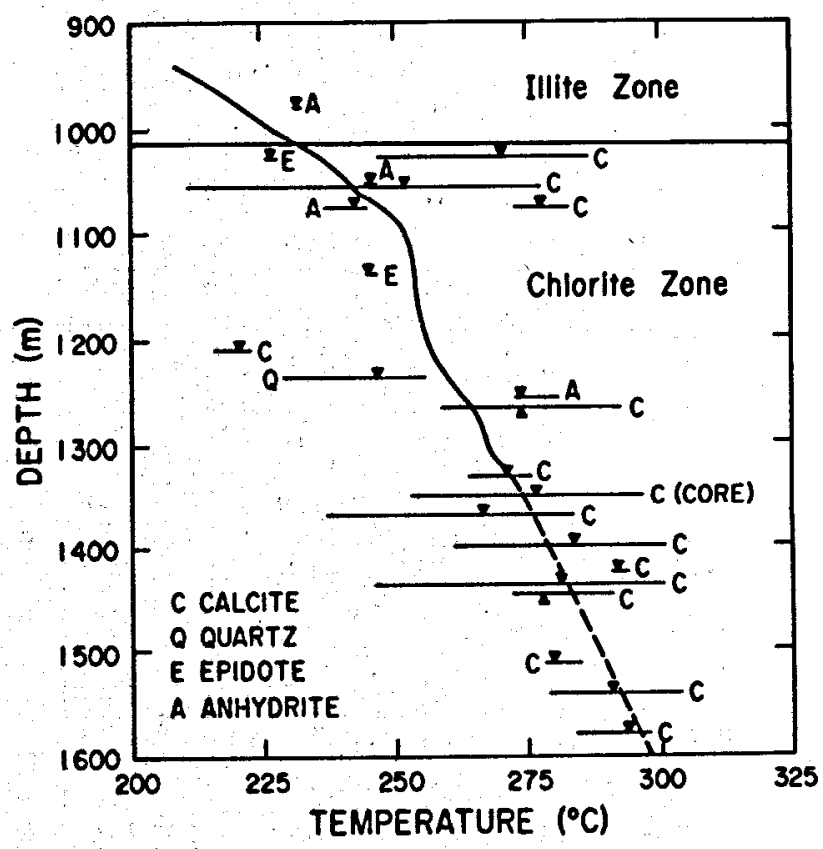

Figure 7. Temperature data for well Sinclair 4 (Randall, 1974) and fluid inclusion homogenization temperatures. Horizontal bar Indicates range of homogenization temperatures at a given depth. Triangle indicates the mean homogenization temperatures at a given depth (after Freckman, 1978). 


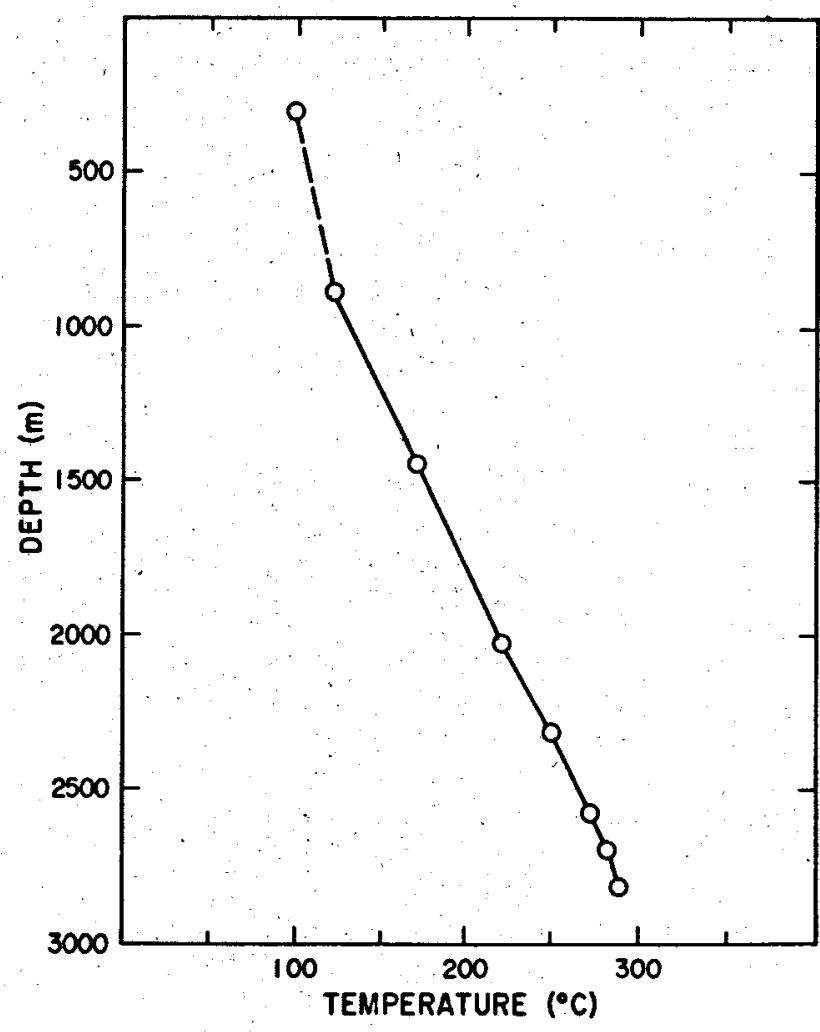

Figure 8. Temperature data for well Britz 3 (Republic Geothermal, Inc.).

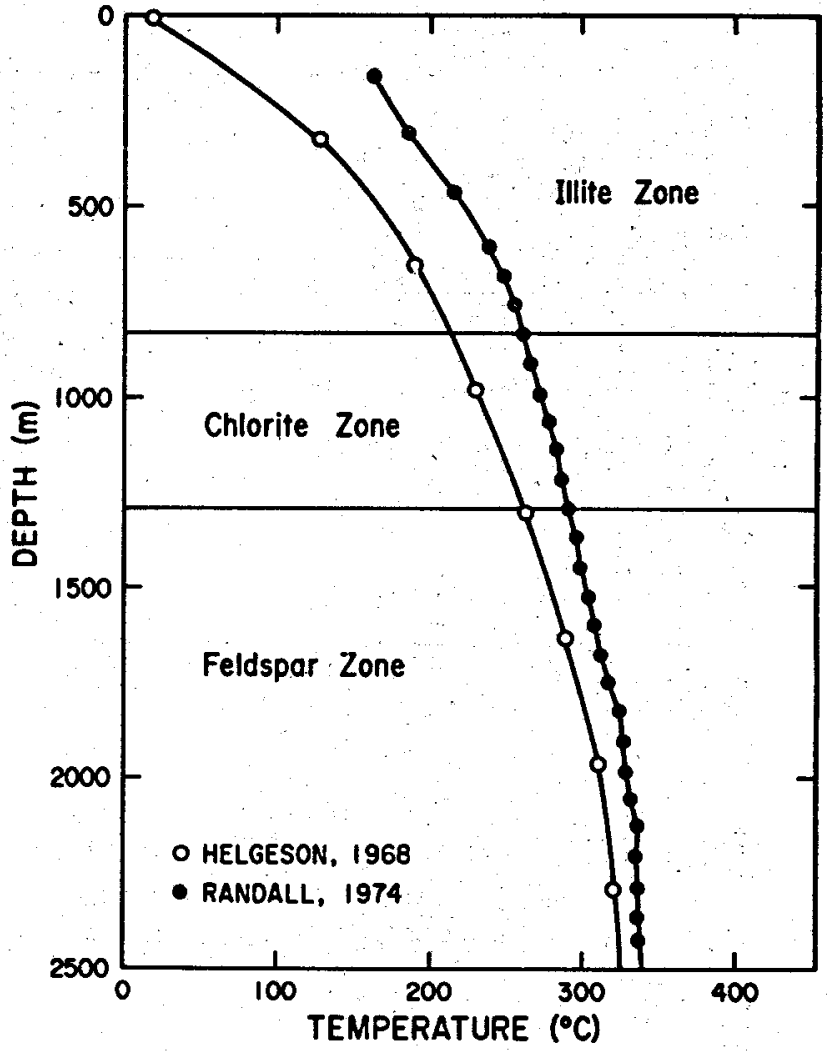

Figure 9. Temperature data for well River Ranch 1, after Randall (1974).

The montmorillonite zone that extends below the lacustrine sequence (Randall, 1974) shows a deep induction resistivity of both sandstone (Rsd) and shales (Rsh) ranging from $0.7 \mathrm{ohm}-\mathrm{m}$ to $1.2 \mathrm{ohm}-\mathrm{m}$. The gamma-gamma densitjes of the sandstone $\left(\rho_{B s d}\right)$ and shale $\left(\rho_{B s h}\right)$ are always low $\left(<2.2 \mathrm{gm} / \mathrm{cm}^{3}\right)$. Within the illite Eone, highly variable Rsd and Rsh values are normally present. An overall rise in $\rho_{B s d}$ and $\rho_{B s h}$ occurs, al though both show some variation. Within the Bşlorite ${ }_{B}$ onhe, $R$ and $\rho_{B}$ for both lithologies generally rise and parallel each other with increasing alteration. The $\rho_{B s h}$ rises to values between $2.40 \mathrm{gm} / \mathrm{cm}_{3}^{3}$, while the $\rho_{B s d}$ reaches values of $2.25 \mathrm{gm} / \mathrm{cm}^{3}$ to $2.40 \mathrm{gm} / \mathrm{cm}^{3}$. The feldspar zone, the hottest zone studied in this report, typically shows resistivities values diverging at the top of this zone -- Rsd usually drops and the Rsh rises. The $\rho_{\text {Bsd }}$ are generally about the same as the chlorite zone (between 2.25-2.35 $\left.\mathrm{gm} / \mathrm{cm}^{3}\right)$. $\rho_{\text {Bsd }}$ occasionally rises in this zone. In the Westmorland geothernal area, only one well shows equivalent well log responses corresponding to mineral zones. An explanation of these different log responses and reasons for the typical $\log$ responses in the SSGS and WGS will be given in a later section (see pages 24-33). 


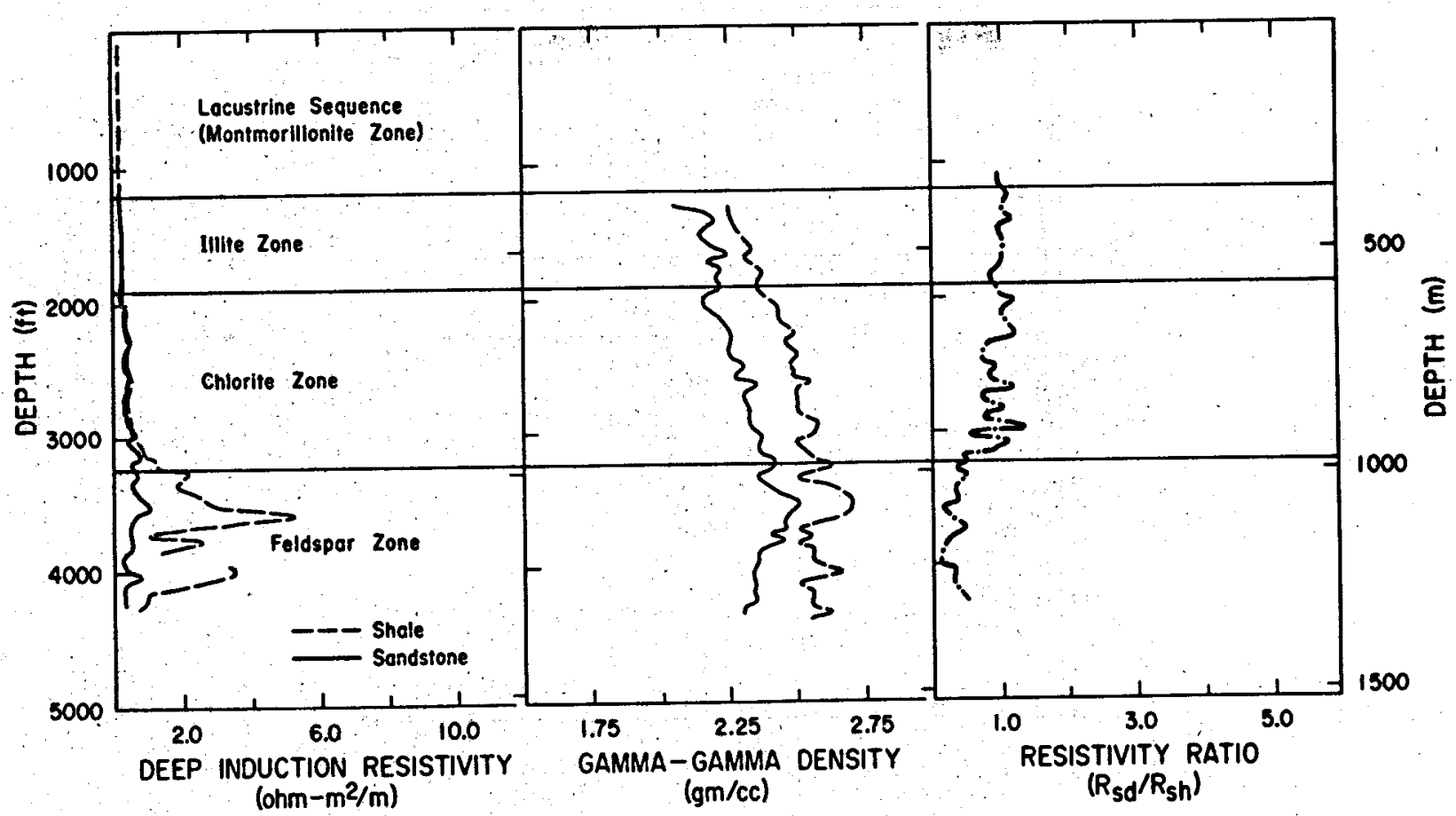

Figure 10. Well Magmamax 2, well log data vs. depth.

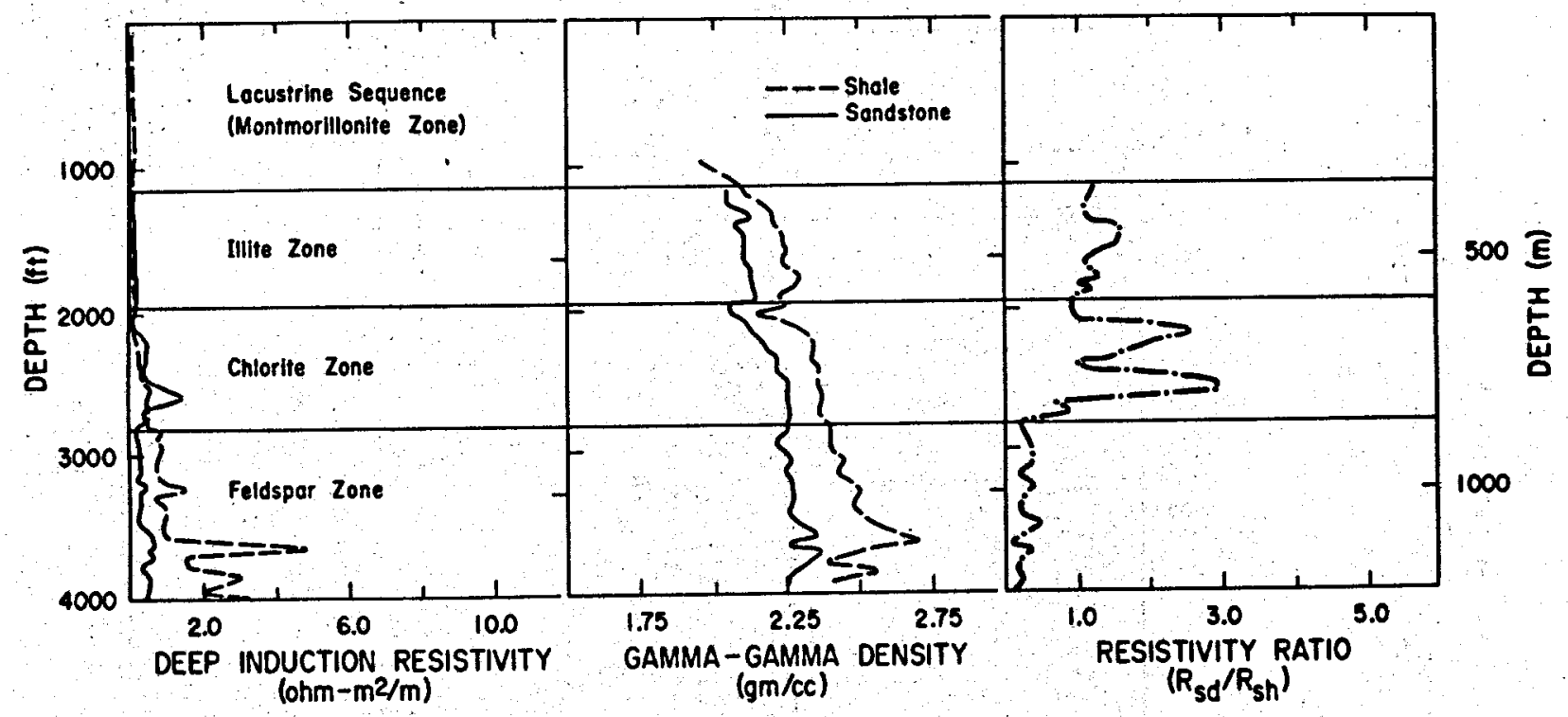

Figure 11. Well Magmamax 3 , well log data vs. depth. 


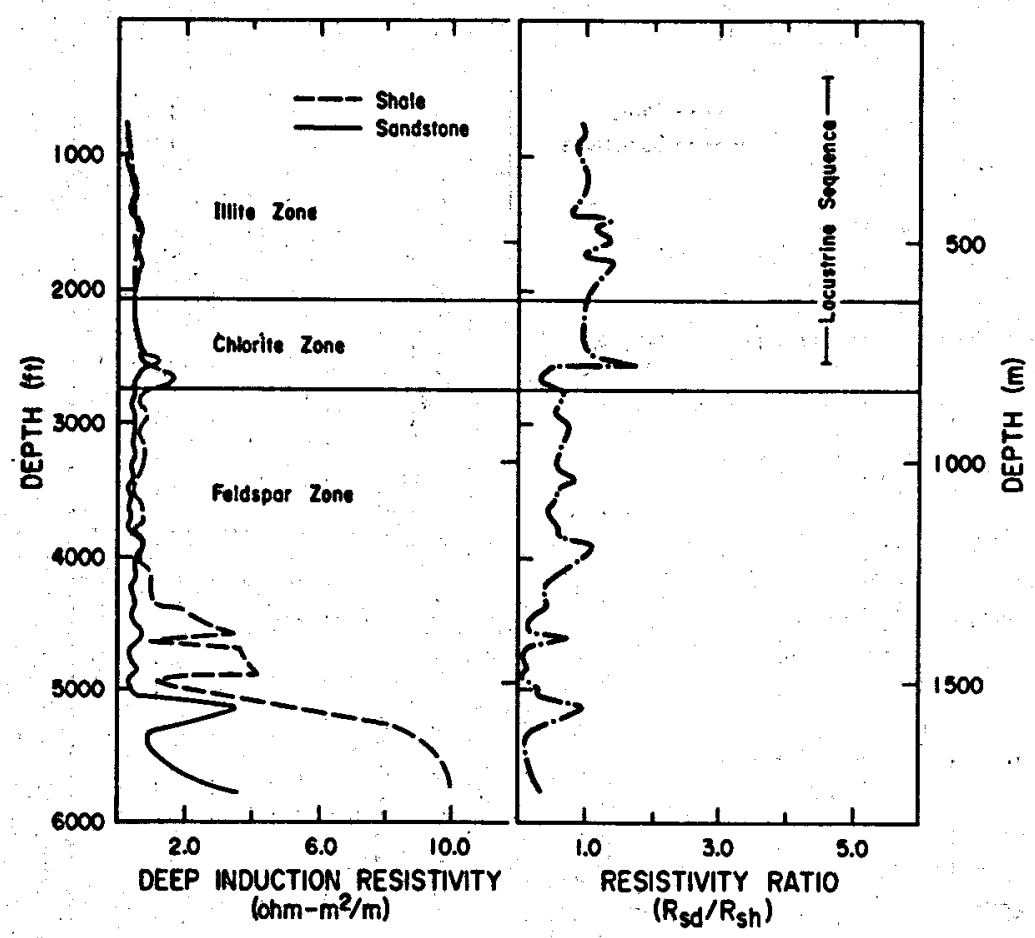

Figure 12. Well I.I.D. 2, well log data vs. depth.

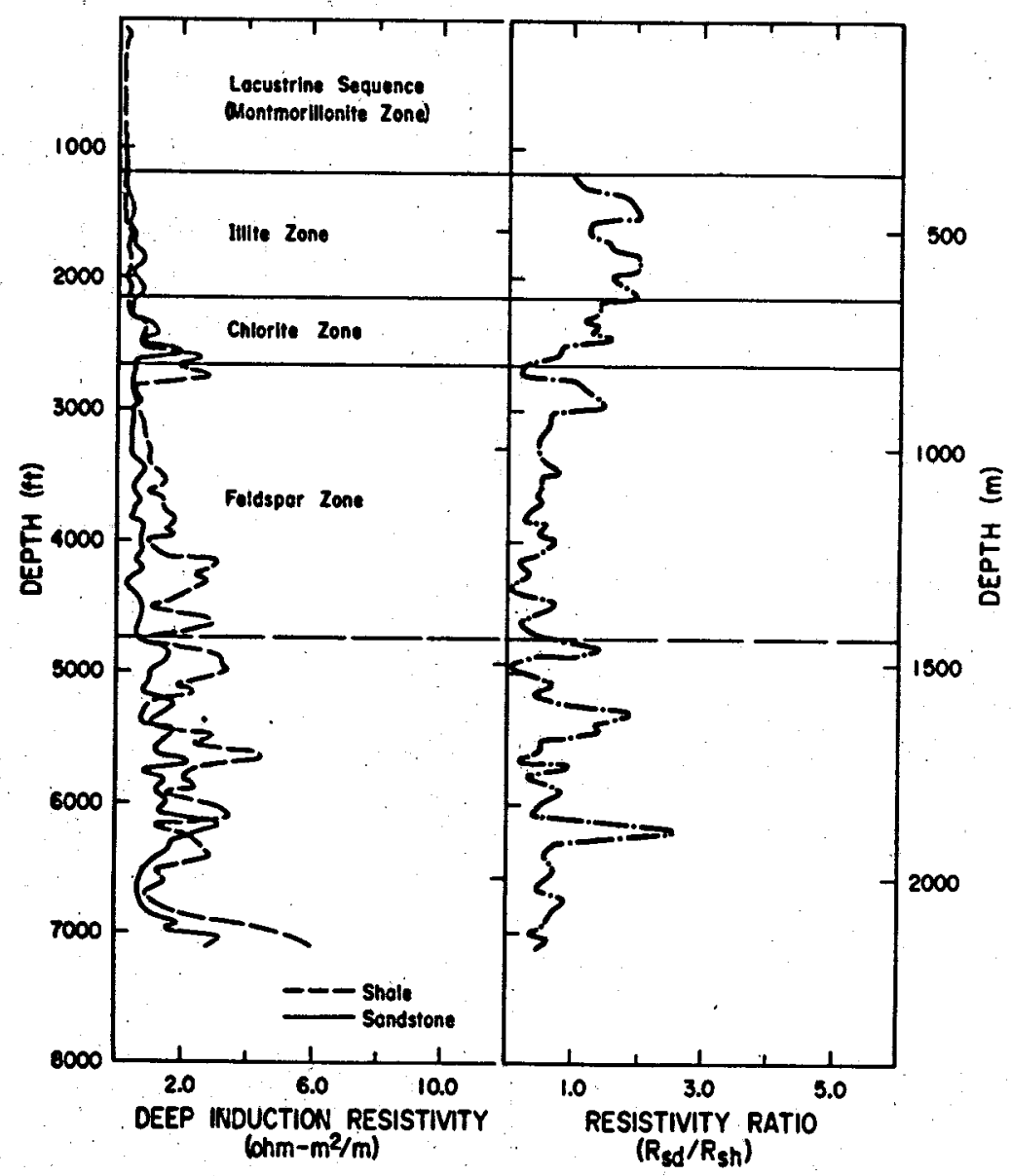

Fịgure 13... Wel1 Elmore 1, well log data vs. depth. 


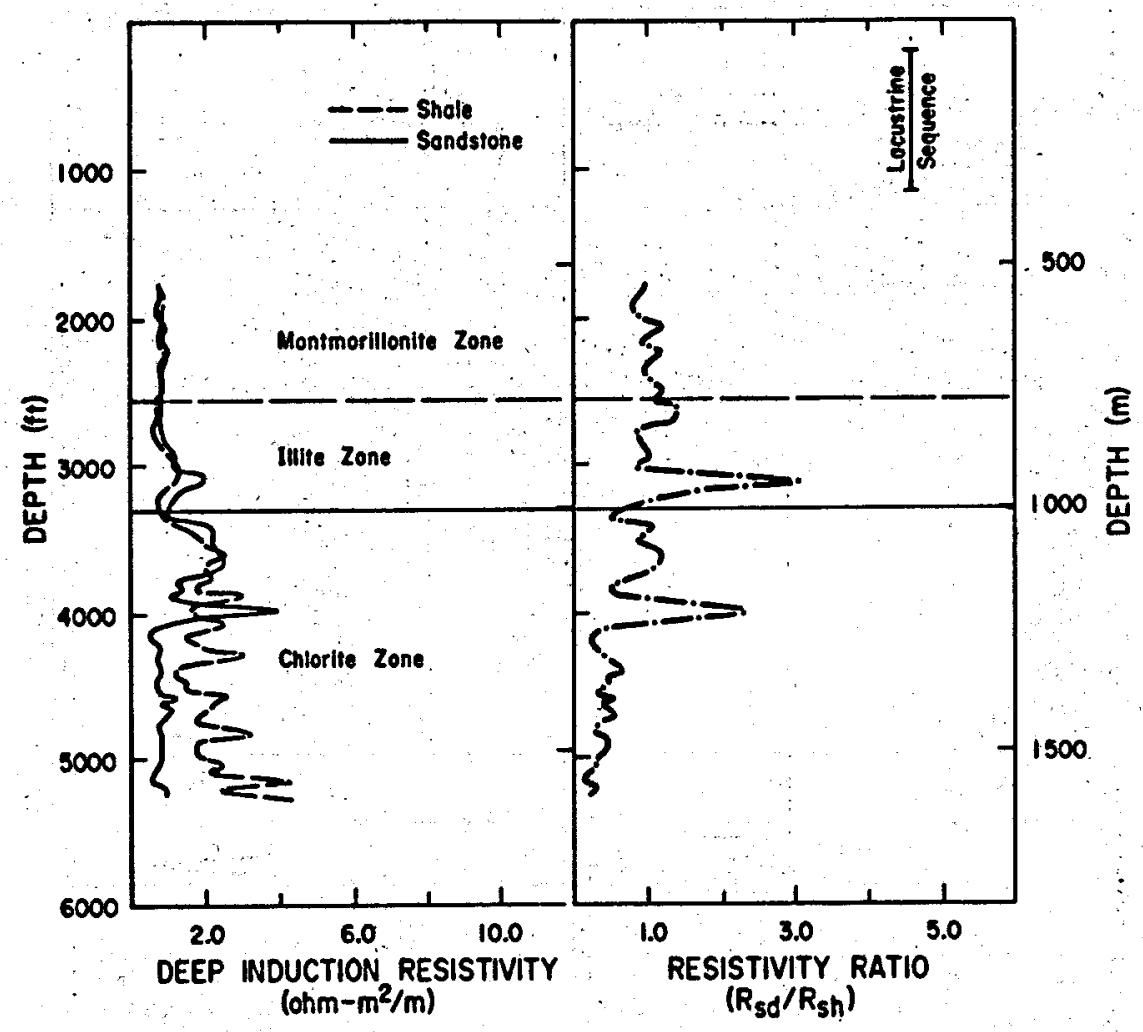

Figure 14. Well Sinclair 4, well log data vs. depth.

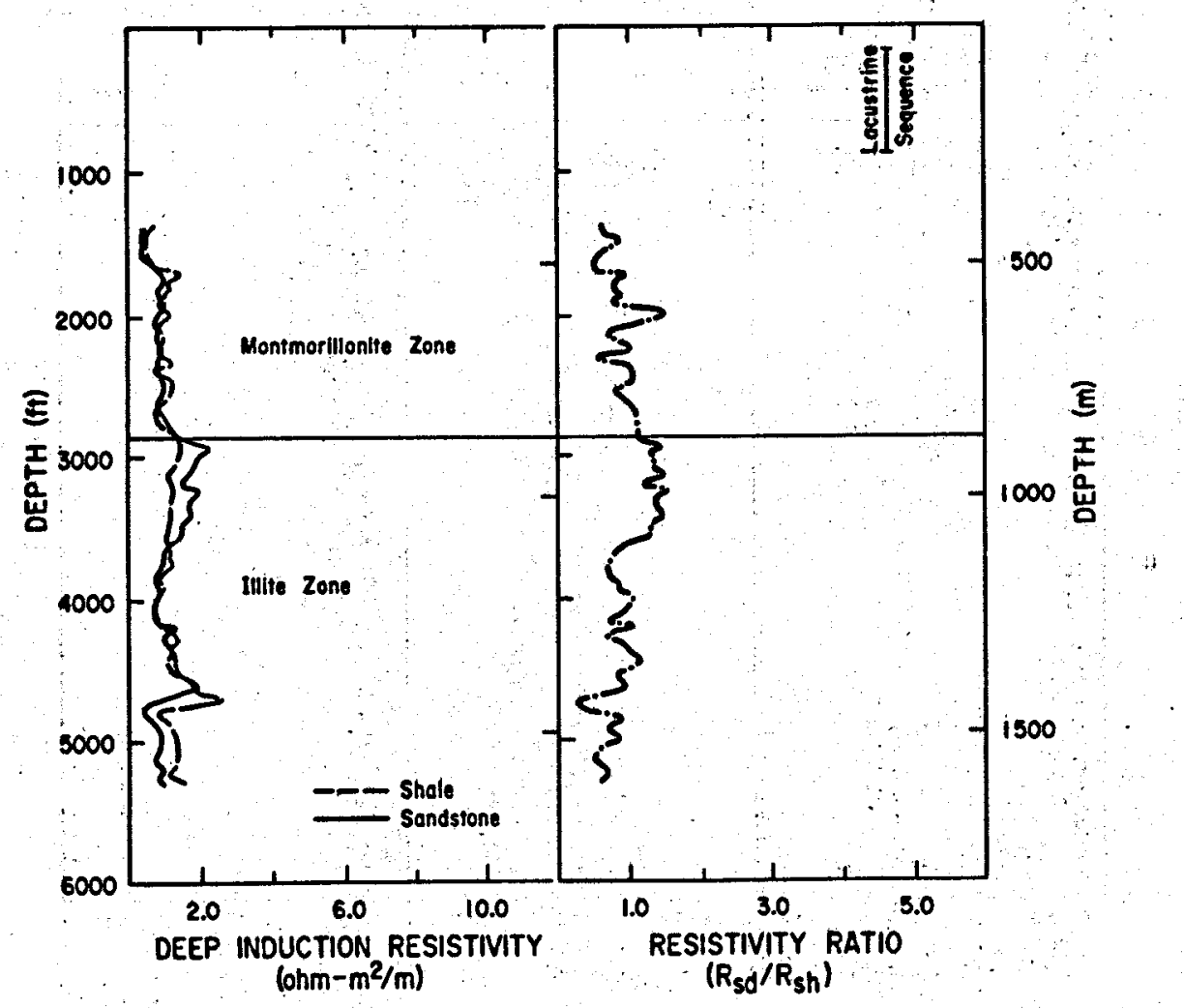

Figure 15. Well Sinclair 3, well log data vs. depth. 


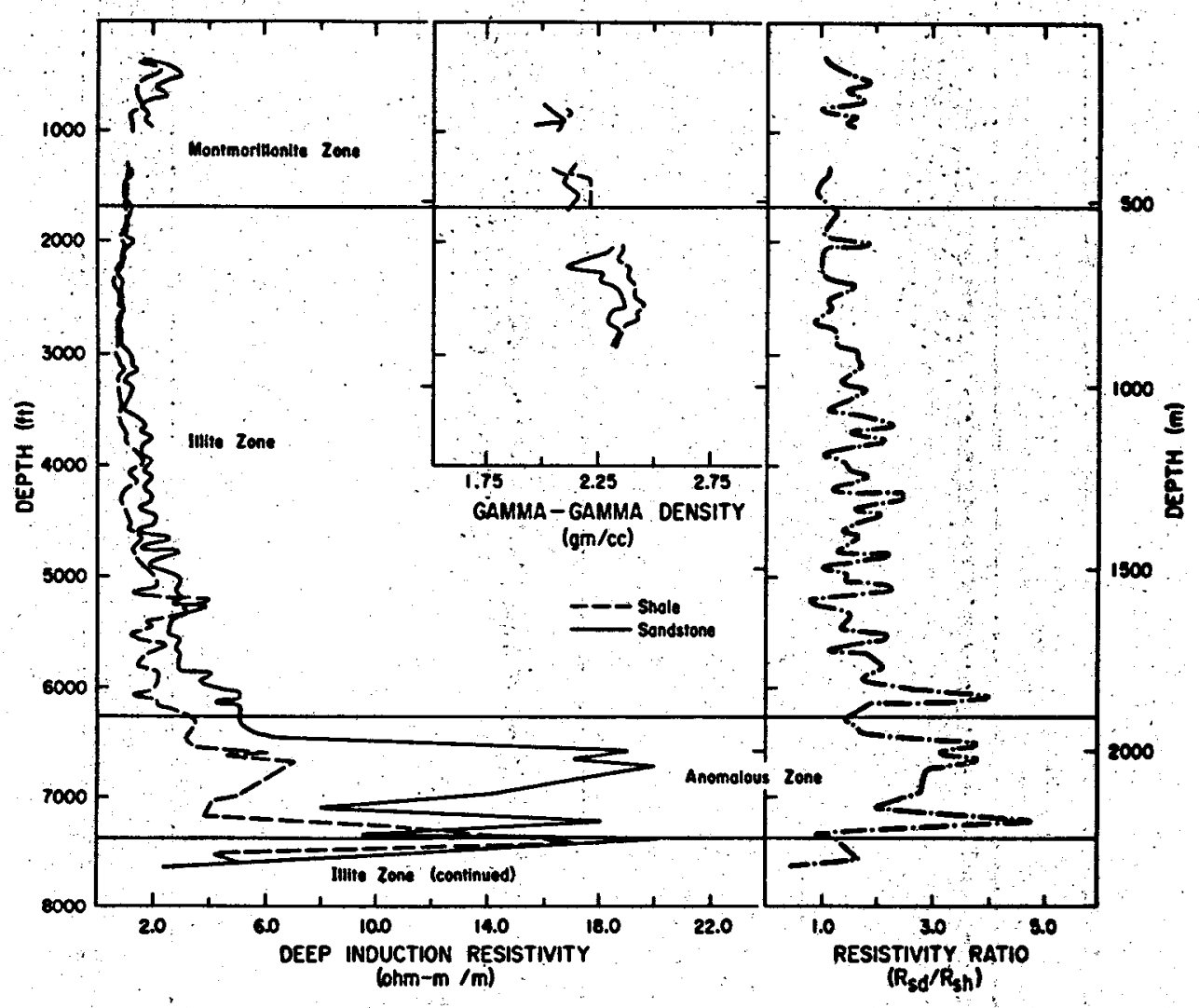

Figure 16. Well Britz 3, well log data vs. depth.

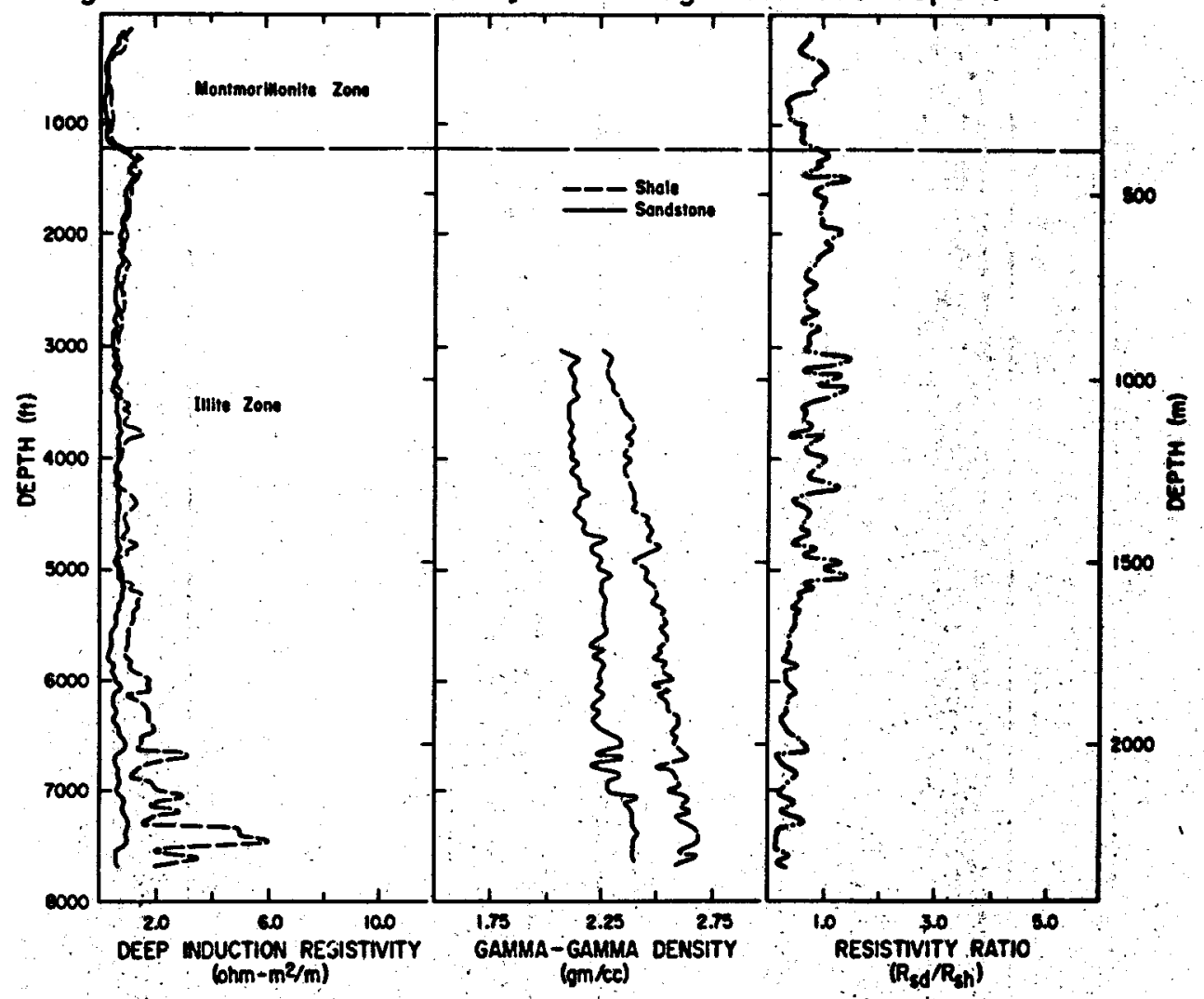

Figure 17. Well Landers 1 , well log data vs. depth. 


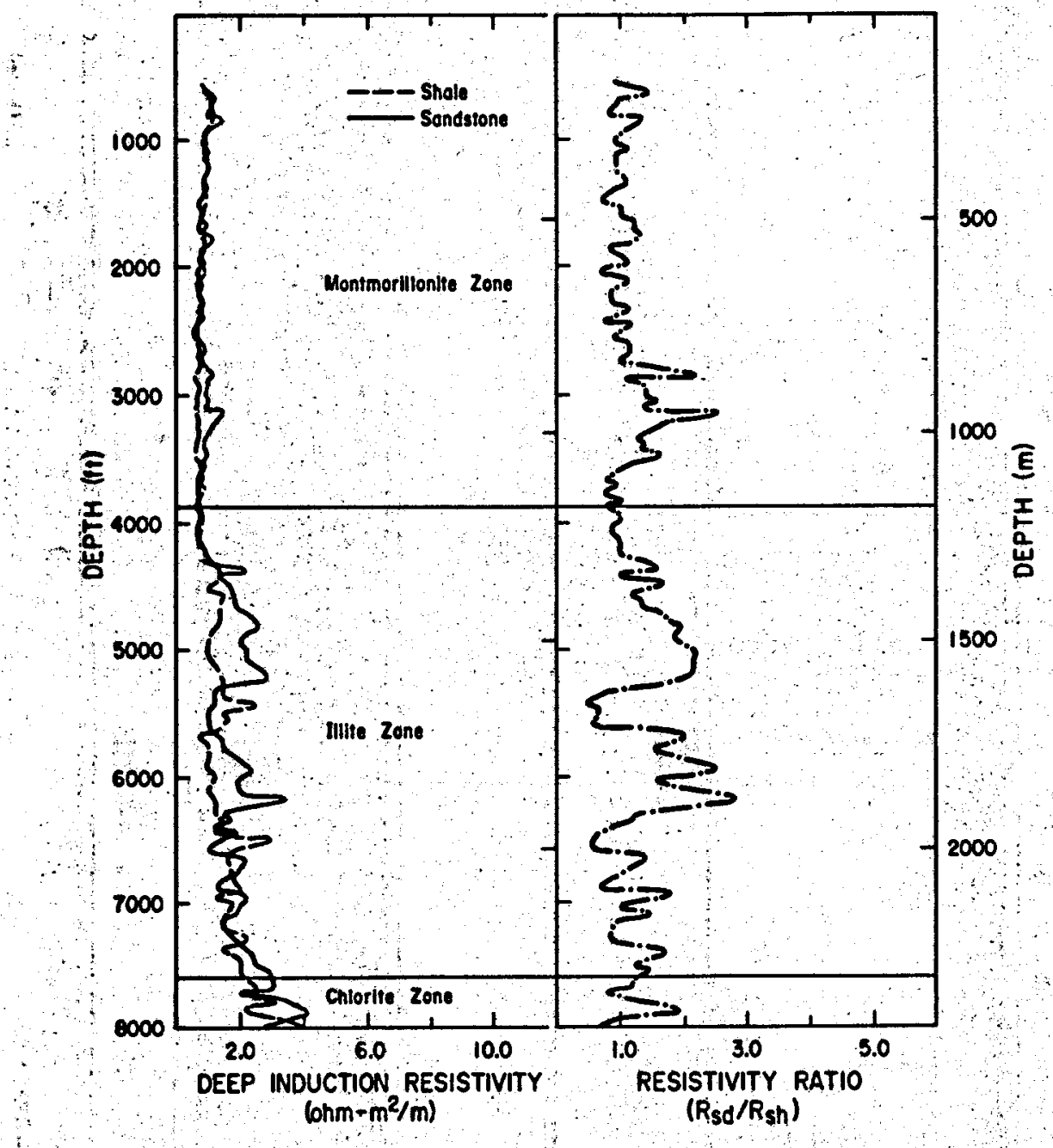

Figure 18. Well Kal in Farms 1, well log data vs. depth. 


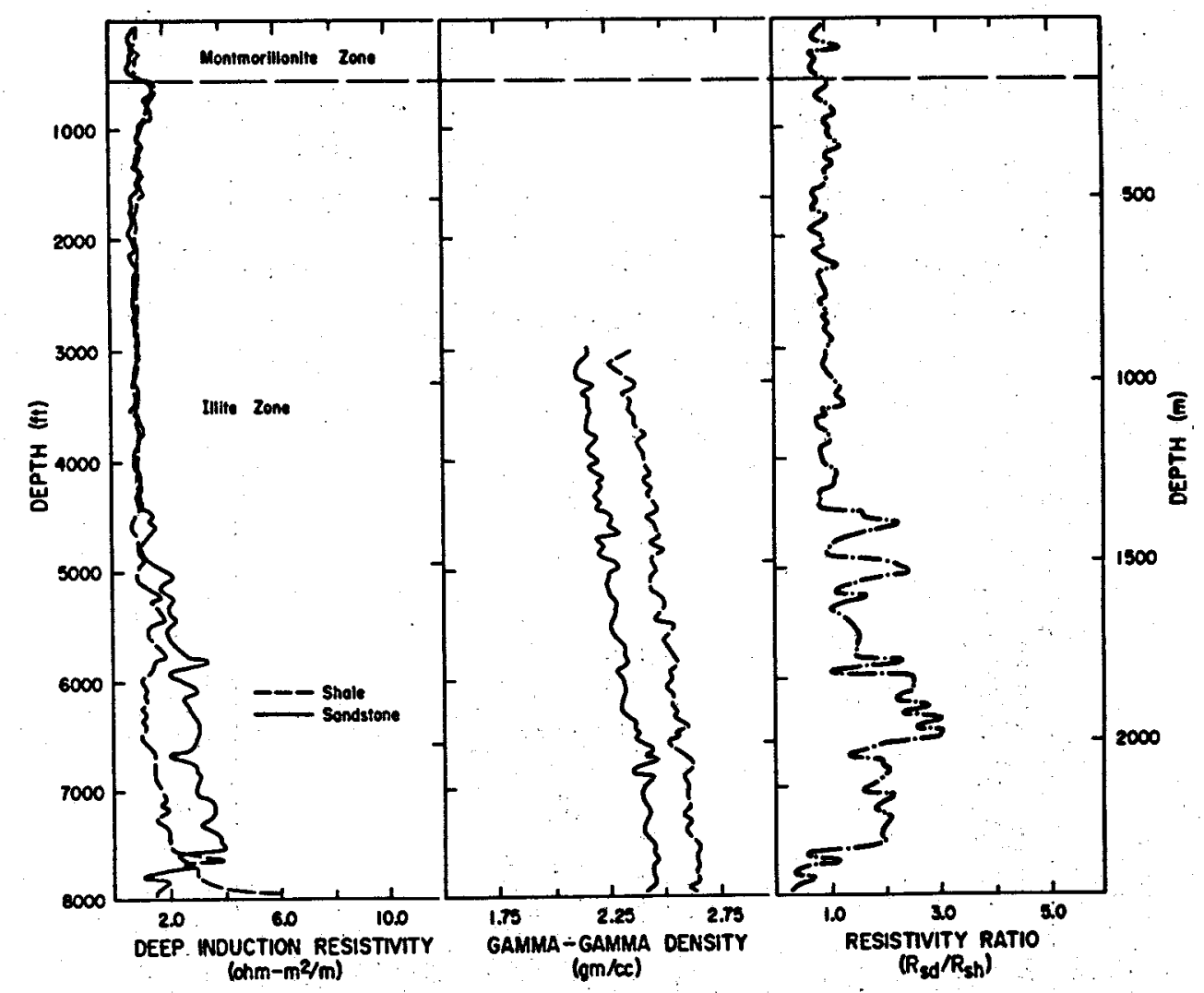

:igure 19. Well Dearborn Farms 1, well log data vs. depth.

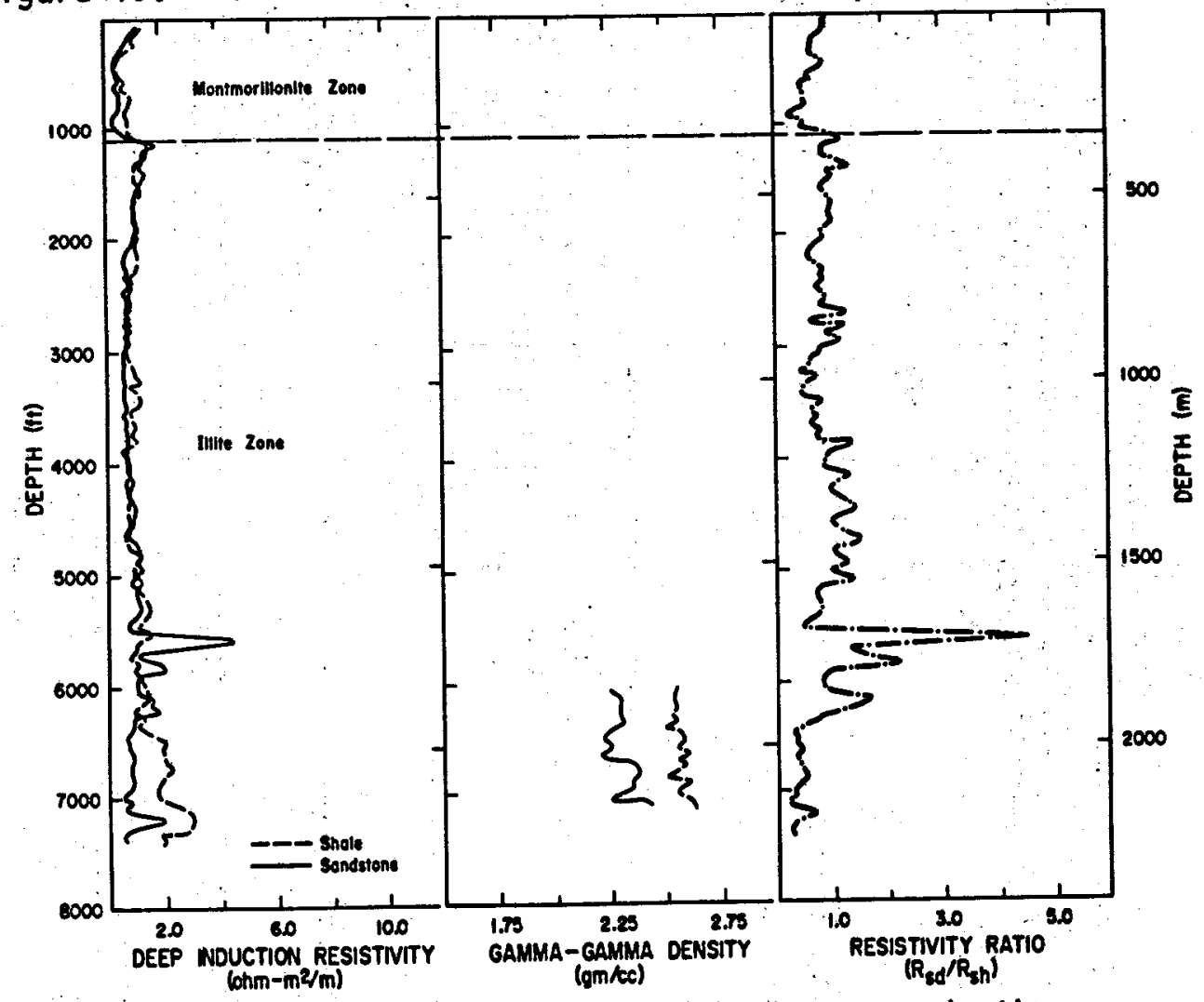

Figure 20. We11 Landers 2, well $\log$ data vs. depth. 
Table 2. Characteristic Log Response and Hydrothermal Mineralogy Within the Four Mineral Zones

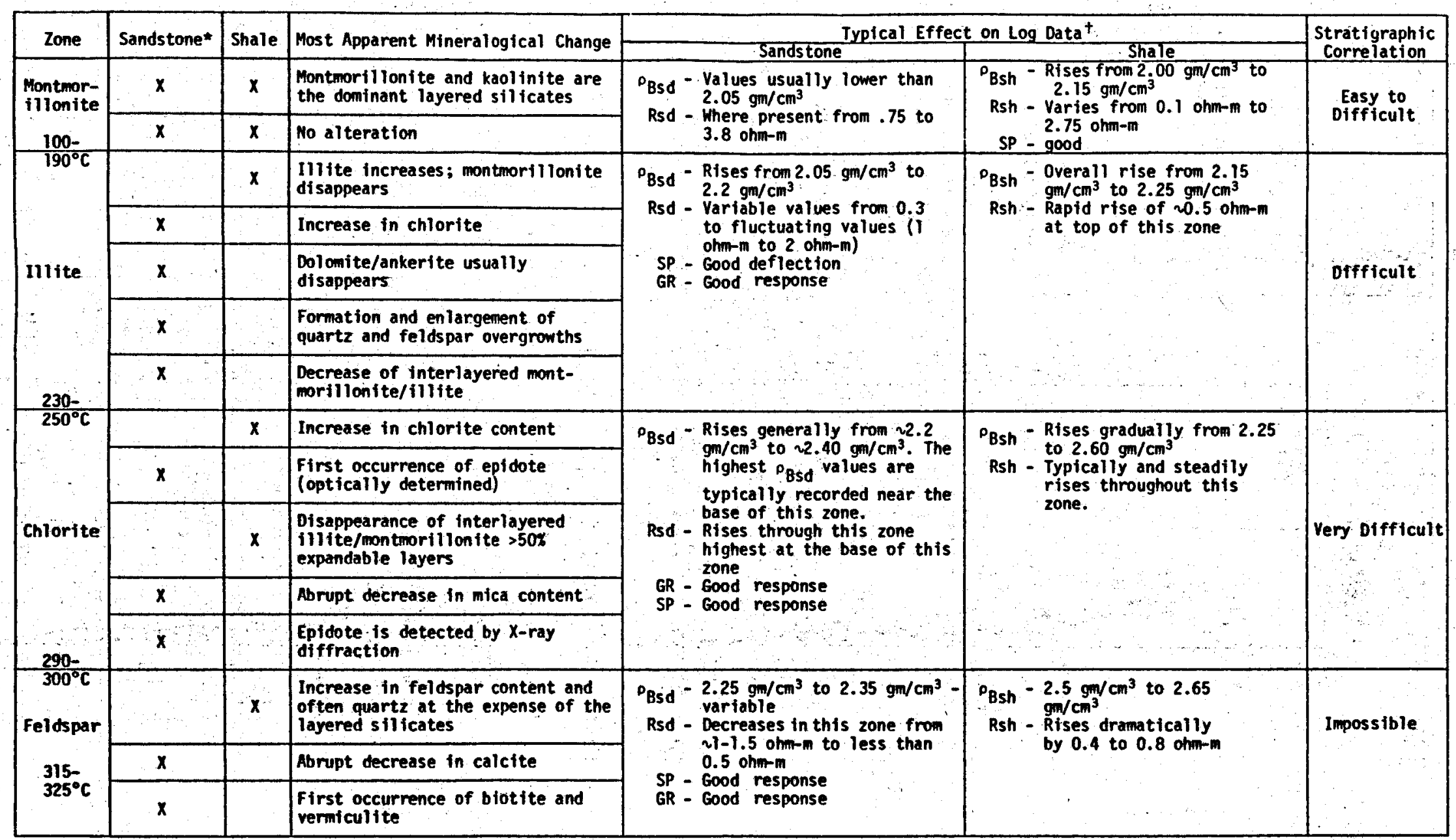

Mineralogy from McDowell and EIders, 1979.

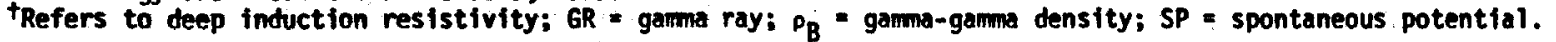


B. Rsd/Rsh vs. Depth

Another method employed to discriminate between the four mineral zones is the Rsd/Rsh versus depth presentation. This type of plot is constructed by dividing the deep induction resistivity of the sandstones (Rsd) by the deep induction resistivity of the shales (Rsh) and crossplotting this dimensionless ratio against depth (Figures $10-20$ ). The resistivity ratio applies to $10 g$ data within a 50-ft $(15-m)$ interval. Both lithologies are therefore shown on a twodimensional display on this plot.

Where the montmorillonite zone extends below the lacustrine sequence in the SSGS, the resistivity ratio ranges from 0.60 to 1.2 . The $i l l i t e$ zone values found near the center of the field vary from 0.8 to 2.0 . The ratio within the chlorite zone normally shows a lower range from 0.3 to 1.5 . The scatter of values in the ratio are least in the feldspar zone where the values ordinarily lie between 0.1 to 0.4 . The divergence of values from these given ranges are attributed to variations in mineralogy physical properties of the rocks and to variations in fluid salinity which chiefly affect sandstones.

C. Resistivity-Density Crossplot

The resistivity-density crossplot, commonly used in the petroleum industry to determine water saturation (Schlumberger, 1972), also differentiates the mineralogic zones. These crossplots were produced for the wells which had the most complete density data, namely Magmamax 2 (Figure 21) and Magmamax 3 (Figure 22). The crossplot was not applied to wells Landers 1 and Dearborn Farms 1 because of the lack of gamma-gamma density data for the upper portions of these wells where the only mineral zone boundaries exist.

This crossplot functions well in identifying the mineral zones using shale data. Yet, overlap of some plotted zones does occur, for example, in well Magmamax 3. Overlapping of these mineral zones takes place because resistivity is affected not only by mineralogy but also by rock properties and formation

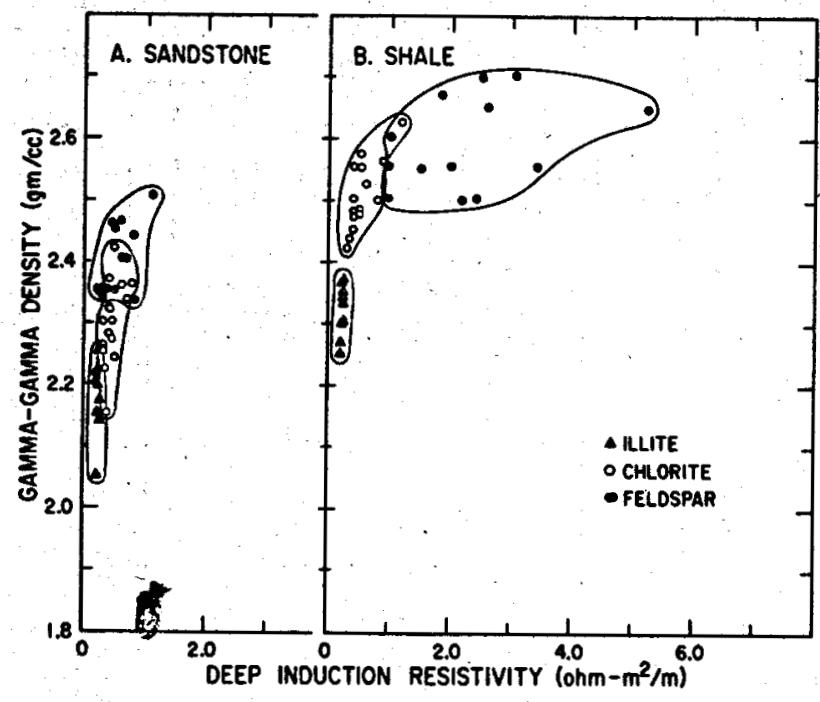

Figure 21. Resistivity-density crossplot for well Magmamax 2.

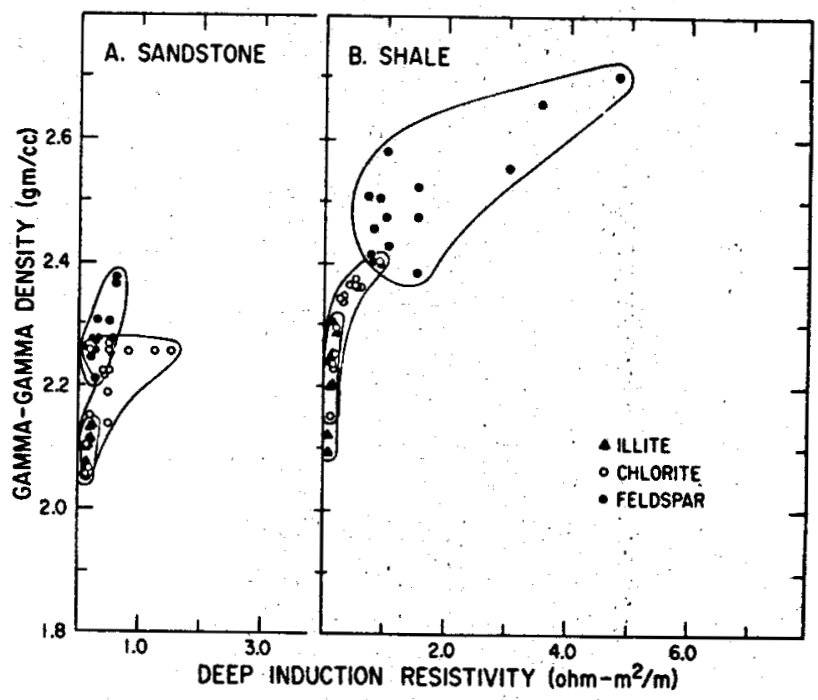

Figure 22. Resistivity-density crossplot for well Magmamax 3 . 


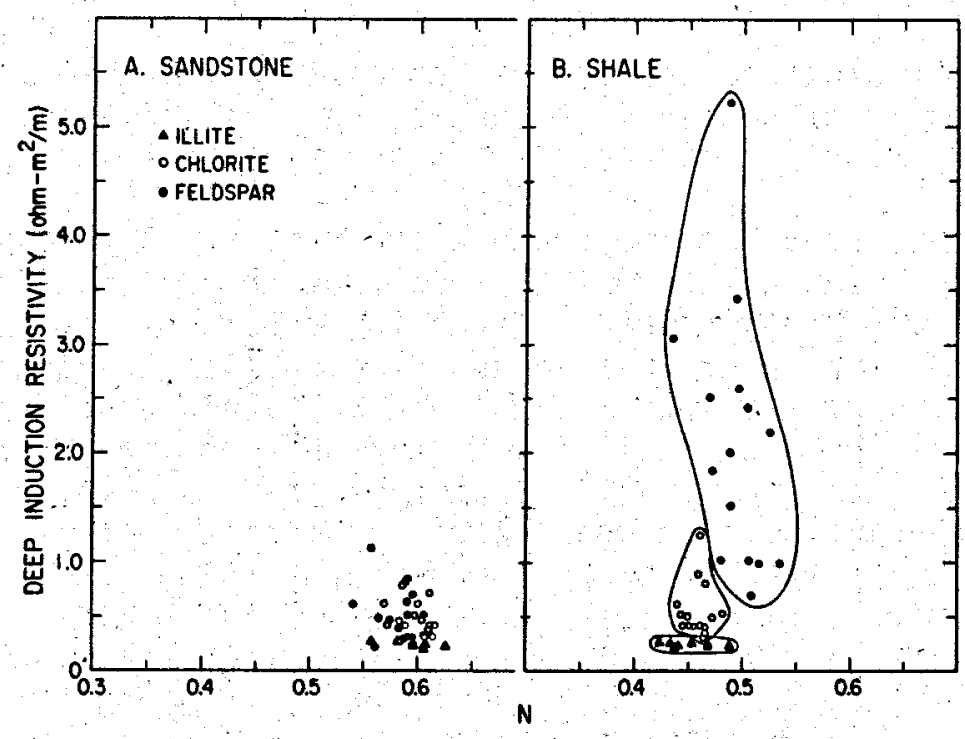

Figure 23. N-Resistivity crossplot for well Magmamax 2.

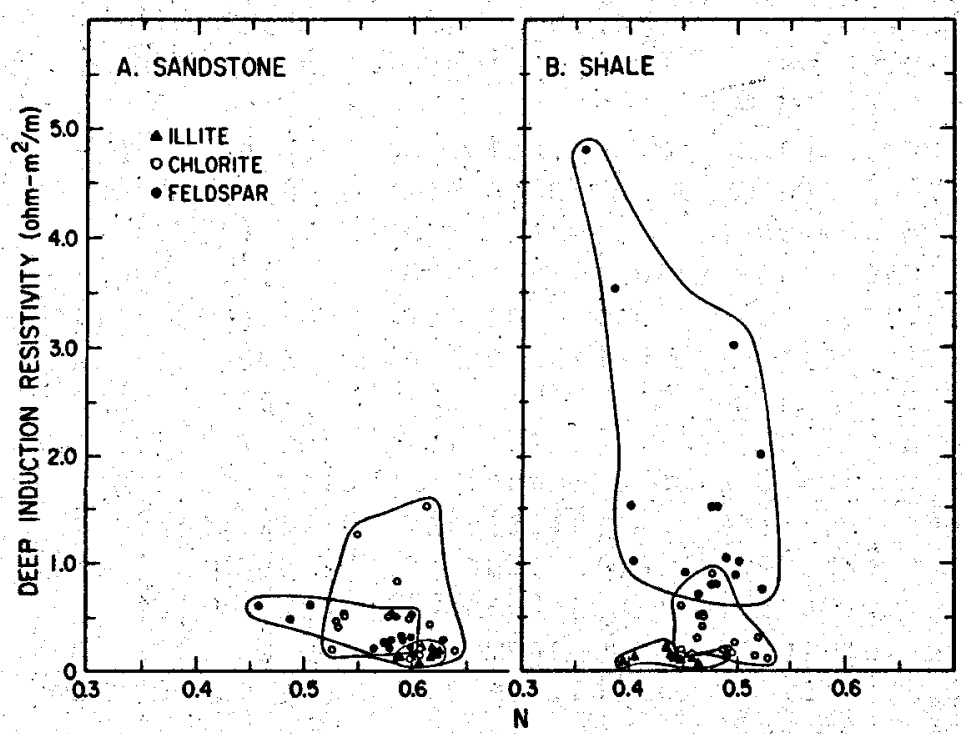

Figure 24. N-Resistivity crossplot for wel1 Magmamax 3. fluid characteristics. In sandstones, this crossplot is less successful in separating mineral zones (Figures 21, 22). A shortcoming of the resistivity-density crossplot is that only one type of 1ithology is presented on a given crossplot. To give the best possible correlations, both sandstones and shales should be analyzed together.

D. N-Resistivity Crossplot

The N-resistivity crossplot is a variation of the $M-N$ crossplot of Burke et al. (1969). $N$ is defined as the neutron porosity divided by density. Since porosity usually decreases with increasing alteration, this display takes into account another variable that affects $\log$ response. As a result, this method discriminates between mineral zones better than the resistivitydensity crossplot (Figures 23, 24). The application of this crossplot was limited to two wells, Magmamax 2 (Figüre 23) and Magmamax 3 (Figure 24), since density and/or neutron porosity data are absent over important intervals in the other wells that were studied. In sandstones the crossplot is unsuccessfur in separating the zones. 


\section{MINERAL ZONE IDENTIFICATION ON LOGS}

A thorough discussion of the characteristic $\log$ responses to varying degrees of hydrothermal alteration is presented in this section. "The emphasis will be placed on the reasons for these $10 \mathrm{~g}$ responses. In addition, atypical cases will also be discussed.

As previously mentioned, with increasing temperature the sandstones and shales of the Salton Sea and Westmorland geothermal systems show characteristic zones of hydrothermal alteration mineralogy. . These sediments, a part of the Colorado River Delta, are heterogeneous in grain size and sorting (van de Kamp, 1973; Muffler and Doe, 1965). There are various lateral and vertical variations in lithology, mineralogy, and formation water salinity within both unaltered and altered sediments. Nevertheless, water-rock reactions at high temperatures are transforming these heterogeneous sediments into characteristic mineral assemblages which vary little between wells at equivalent temperatures. Thus, with increasing alteration the distinction of mineralogy and texture between different sedimentary units becomes less apparent. The log data reflect this tendency towards homogenization. For example, the resistivity ratio (Figures 10-20) for the 111 ite zone generally ranges from 0.8 to 2.0 . With increased alteration in the feldspar zone, the range in values is restricted to 0.1 to 0.4 .

In the SSGS, hydrothermal alteration has affected all of the logs studied in similar ways, al though slight variations in log signatures do exist. These variations probably result from local mineralogic and stratigraphic differences.

Each mineral zone has its own characteristic log response which will be elaborated upon in the following sections. Thus, mapping of the altered zones from log data from well to well is possible.

The primary factor that produces the characteristic log responses in the Salton Sea and Westmorland geothermal areas is the progressive dehydration of clays and their final alteration to feldspars. Johnson and Linke (1977) [cited in Ershaghi et al..,1980, 1981]) have classified clays into effective and ineffective types based on resistivity. The clays, montmorillonite and illite, are considered effective because of their high cation exchange capacity and high surface conductivity (Grim, 1953, pages 125-155). This high surface conductivity causes an overall lowering of electrical resistivity. Ineffective clays, such as chlorite and kaolinite, have low cation exchange capacity and thus low conductivity. Furthermore, the general rise in resistivity associated with increased alteration indicates that the lower temperature clays such as montmorillonite and illite have more exchangeable sites than high-temperature, less hydrated clays. Other factors that influence log parameters are changes in porosity caused by induration and mineral precipitation and large changes in formation water salinity in and between wells.

The changes in mineralogy of the shales affect $\log$ parameters to a greater degree than the changes in mineralogy of the sandstones. Changes in sandstone mineralogy have a more subtle effect on $10 \mathrm{~g}$ responses because of the major influences of the formation fluids within the larger pore spaces of these clastic rocks.

In this study the available logs for examination were the dual inductionlaterolog (DIL), the induction electrical survey (IES), gamma-gamma density, and neutron logs. If additional wireline logs had been run in these wells, it would have been likely that the mineral zones could be more easily delineated. For example, the M-N plot (Burke et al.. 1969) which incorporates sonic, gamma-gamma density, and neutron porosity data would probably be effective in distinguishing the mineral zones in the Salton Sea and Westmorland areas. 
Because of their inherent differences, a discussion of the Salton Sea and Westmorland geothermal systems will be given in separate sections. Problems in log interpretation in the Westmorland field exist which will be addressed separately.

\section{A. Salton Sea Geothermal System}

1. Montmorillonite Zone. The montmorillonite zone is postulated to be present in all of the wells studied in the SSGS since montmorillonite, the characteristic mineral of this zone, is a component of the original detrital clay mineralogy (Muffler and White, 1969). However, this zone has been identified by $x$-ray diffraction studies of shale cuttings (Appendix 2) in only two wells, Sinclair 3 and Britz 3. The major reasons for its absence in cuttings from five other thoroughiy studied wells in the SSGS are, firstly, poor sampling of the shallower parts of the wells and, secondly, the removal of expandable clays with repeated washing to remove drilling mud. The authors have, however, defined the lower boundary of the montmorillonite zone in well sinclair 4 at $2750 \mathrm{ft}(838 \mathrm{~m})$ (Figure 14 ) based on its similarity in $\mathrm{log}$ response to well Sinclair 3 (Figure 15). Furthermore, the close proximity of these two wells makes extrapolation of this zone boundary possible. For wells Elmore 1 (Figure 13) and Magmamax 2 and 3 (Figures 13 and 14, respectively), the base of this zone has been correlated with the base of the lacustrine sequence (Randall, 1974). Reasons for this correlation are explained in detail in the following section and on pages 32-33.

The sediments in the montmorillonite zone are mostly unconsolidated. Claystones, the dominant lithology, are generaliy soft and light brown in color. The deep induction resistivities of these claystones are intermittently greater than those of the sandstones to depths as deep as $2700 \mathrm{ft}$ ( $823 \mathrm{~m}$ ) in well Sinclair 3 (Figure 15). The fluctuations of the shale resistivity values with depth are difficult to explain. One possible explanation is that the higher shale resistivities might be the result of the expulsion of more saline pore fluid through compaction and ionic membrane filtration, leaving fresher interstitial water (Englehardt and Gaida, 1963). The fresher interstitial pore water will cause higher Rsh values. Another explanation might be due to the conditions under which the clay particles were originally deposited. These conditions include the concentration and acidity of the initial pore solutions, particle size, and rate of deposition (Meade, 1964). For example, in low electrolytic solutions with slow depositional rates, the clay particles will become preferentially arranged in comparison to more random orientation in different conditions, as depicted in Figure 25. The preferentially arranged particles (case A, Figure 25) result in more rapid porosity reduction with burial. Consequently, at equivalent depths the resistivities associated with case $A$ (Figure 25) will probably be higher than case B (Figure 25).

2. Illite Zone. Locating the upper boundary of the illite zone is difficult in many wells of the SSGS. In the central portion of this field near well Elmore 1, the montmorillonite-1llite zone boundary presumably lies within the lacustrine sequence, since montmorillonite is not present in the 1 imited shale $x$-ray diffraction data for the lacustrine sequence (e.g., wells Magmamax 2 and 3 , Appendix 2). Because the boundary cannot be precisely located in wells Magmamax 2 and 3 and Elmore 1, the top of the fllite zone for these wells has been correlated with the base of the lacustrine sequence (see pages 32-33 for a more detailed explanation). 


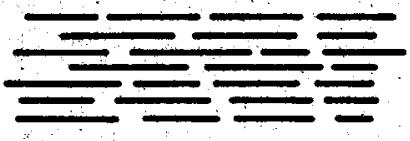

CASE A

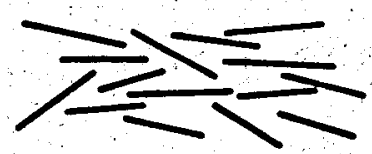

CASE B
Figure 25. A comparison of clay particle orientation for different conditions during sedimentation (after Magara, 1978). Case A: Slow depositional rates and low electrolytic conditions. Case B: Fast depositional rates and high electrolytic conditions.
The o shows a general rise through this zone although consideráble density variations do exist with depth. These fluctuations suggest that selective induration of some sandstones takes place, while others are left unconsolidated. This occurrence is probably the result of primary permeability and original density/packing of the sediments.

The $\rho_{B S h}$ also increases throughout Bshe illite zone. At the top of this zone in wells Magmamax 2 (Figure 10) and Magmamax 3 (Figure 11), the $\rho_{B s h}$ displays an increase of about $0.1 \mathrm{gm} / \mathrm{cm}^{3}$ within $200 \mathrm{ft}$ $(70 \mathrm{~m})$. This increase occurs at the interface of the lacustrine sequence and the sand-shale deltaic sequence. Since the permeability of the deltaic sediment sequence is presumably greater than the lacustrine sequence, more extensive water-rock interactions have taken place in the deltaic sequence, which results in sediment induration. This probably causes the increase in density at the top of this zone. Furthermore, for well Britz 3 (Figure 16) a rapid rise in ${ }^{\rho_{B s h}}$ also occurs at the top of this zone. These wells show inordinately high Bsh $\left(\sim 2.2 \mathrm{gm} / \mathrm{cm}^{3}\right)$ for depths as shallow as $1500 \mathrm{ft}(457 \mathrm{~m})$. Hydrothermal alteration has indurated these sediments since compaction is insufficient to cause densities this high at such shallow depths in young sediments (Athy, 1930).

In wells Elmore 1 (Figure 13), 1.1.D. 2 (Figure 12), and Sinclair 3 and 4 (Figures 15 and 14 , respectively) the Rsd is often greater than the Rsh in this zone. Since density logs are lacking in these wells, a possible correlation of high density with high resistivity due to intense induration cannot be demonstrated. However, in well Sinclair 4. (Figure 14) at $3100 \mathrm{ft}(945 \mathrm{~m})$; the high Rsd readings correlate with an increase in feldspar content from approximately $10 \%$ to $19 \%$ (sandstone $x$-ray diffraction data, Appendix 3 ).

It is interesting to observe that the illite zone is nearly coincident with the carbonate cap as defined by McDowell and Elders (1979) in wells Magmamax 2 (Figure 10) and Magmamax 3 (Figure 11). In the carbonate cap which extends to $1758 \mathrm{ft}(536 \mathrm{~m})$ in Magmamax 2 and $1899 \mathrm{ft}(579 \mathrm{~m})$ in Magmamax 3, the sandstones have very low porosities because of the pervasive pore-filling carbonate cement (MCDowell and Elders, 1979). Thus, high Rsd are expected. The resistivities actually are very low $(0.3 \mathrm{ohm}-\mathrm{m})$. The low resistivities can be explained by the presence of illite and mixed layer clays, both effective clay types in respect to resistivity (Appendix 3) and to the very high salinity.

In well Britz 3 anomalously high Rsd and Rsh values are present between $6400 \mathrm{ft}(1951 \mathrm{~m})$ and $7500 \mathrm{ft}(2286 \mathrm{~m})$. This high resistivity zone is delineated on the lithologic log (Exlog Smith, 1980, from Republic Geothermal, Inc.) as a possible salt intrusion since an increase in $\mathrm{Cl}^{-}$concentration within the circulating drilling mud was noted by the logging geologist. Evaporites are not uncommon in the SSGS and leaching of halite, for example, from them may have caused the increase in $\mathrm{Cl}^{-}$in the drilling mud. 'If this is the case, then resistive minerals such as anhydrite which are components of evaporites may cause the high resistivities in this zone. Furthermore, examination of thin sections from this zone reveal sandstones of low apparent porosity resulting 
from pervasive pore-filling cementation by calcite and anhydrite. Low porosity and resistive minerals such as anhydrite are probable sources for this high resistivity zone. Consequently, close scrutiny of lithologic logs can aid in the identification and cause of anomalous wireline $\log$ responses.

The first obvious occurrence of hydrothermal al teration typicaliy occurs at the top of the illite zone. The limited gamma-gamma density data available for this zone indicate that a rapid rise in shale density occurs at the top of this zone. Through this zone, the pBsh increases from approximately $2.15 \mathrm{gm} / \mathrm{cm}^{3}$ to values near $2.4 \mathrm{gm} / \mathrm{cm}^{3}$, and the $\rho_{B s d}$ rises from $2.0 \mathrm{gm} / \mathrm{cm}^{3}$ to $2.2 \mathrm{gm} / \mathrm{cm}^{3}$. Both Rsd and Rsh show minor variation ind this zone.

3. Chlorite Zone. The depth where both Rsd and Rsh curves begin a paraltel rise with increasing depth indicates the transition into the chlorite zone. This rise, observed in five of seven wells studied in the SSGS, is typically continuous throughout this mineral zone. At the base of this zone, the Rsd and Rsh curves diverge -- the Rsd drops by 1 ohm-m to $1.5 \mathrm{ohm}-\mathrm{m}$, while the Rsh generally continues to rise. Well Magmamax 3 (Figure 11) displays these effects the best. The maximum sand resistivity values vary considerably at the base of this zone from $0.3 \mathrm{ohm}-\mathrm{m}$ in well Magmamax 3 (Figure 11) to 4.4 ohm-m in well Sinclair 4 (Figure 14). In all wells studied, the rise in Rsd is directly related to reduced porosity resulting from quartz-feldspar overgrowth (McDowell and Elders, 1979) and with an increase in sandstone chlorite concentration. Generally, the chlorite concentration in sandstones ranges from $5 \%$ to $13 \%$ but can rise to $15 \%$ as in well Magmamax 2 (Appendix 3 ).

The Rsd of well Sinclair 4 fluctuates greatly in this zone (Figure 14), exhibiting values from about $0.7 \mathrm{ohm}-\mathrm{m}$ to greater than $20 \mathrm{ohm}-\mathrm{m}$. At approximately $3500 \mathrm{ft}(1067 \mathrm{~m})$ the Rsd is greater than $2.4 \mathrm{ohm}-\mathrm{m}$, while below $4100 \mathrm{ft}$ $(1250 \mathrm{~m})$ the values approximate $0.7 \mathrm{ohm}-\mathrm{m}$. This drastic Rsd reduction is believed to be due to a salinity change within the well. Freckman (1978) examined fluid inclusions in authigenic minerals from this well and determined the salinity in $\mathrm{NaCl}$ weight percent equivalent of the entrapped fluid by the depression of the freezing point method. He postulated that two fluids of different brine concentrations, separated by a thick shale layer, are probably present in this well (Figure 26). Since the concentration of the pore fluids has an overriding effect on the resistivity of sandstones, the drastic change in resistivity is most likely related to the presence of two fluids of considerably different formation water salinities.

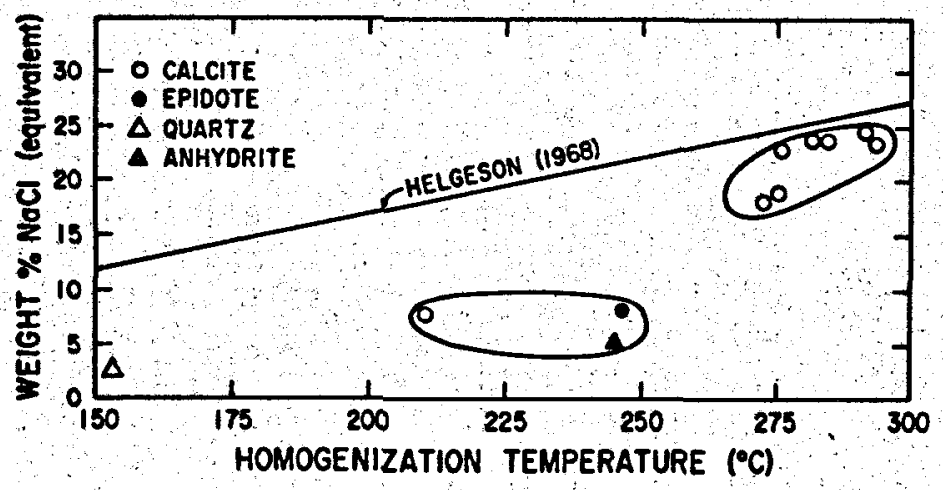

Figure 26. Average sal inity vs. homogenization temperature of fluid inclusion data in well sinclair 4. These values are compared with Helgeson's (1968) calculated unit isochore for a simulated geothermal brine in the system $\mathrm{KCl}-\mathrm{CaCl}_{2}-\mathrm{NaCl}-\mathrm{H}_{2} \mathrm{O}$ ( $\mathrm{KCl}: \mathrm{CaCl}_{2}: \mathrm{NaCl}-1: 1.95: 3.55$ by weight) (after Freckman, 1978). 
In well Magmamax 3 (Figure 11), high Rsd readings occur at approximately $2600 \mathrm{ft}(792 \mathrm{~m})$. These high readings are attributed to a $10 \%$ increase in muscovite, probably a recrystallized phengitic mica (Appendix 2) (the percentage referred to relates to total bulk rock composition).

The increase in the concentration of non-conductive chlorite (Appendix.2) at the expense of the mixed layer clays most likely causes the rise of Rsh within this zone. Even though the illite concentration increases, the enhancement of conductivity is offset by a greater increase in chlorite content.

The $\rho_{\text {Bsd }}$ shows marked fluctuatjon with depth, but an overall rise in density from $2.85 \mathrm{gm} / \mathrm{cm}^{3}$ to $2.42 \mathrm{gm} / \mathrm{cm}^{3}$ is evident in the two well s that have density data within the chlorite zone. In these wells Magmamax 2 (Figure 10) and Magmamax 3 (Figure 11), anomalously low $\rho_{B s d}$ readings occur between $1958-2050 \mathrm{ft}(595-625 \mathrm{~m})$. Three possibilities exist as an explanation of the low $\rho_{\text {Bsd }}$ (1) an enlarged borehole causing low backscatter

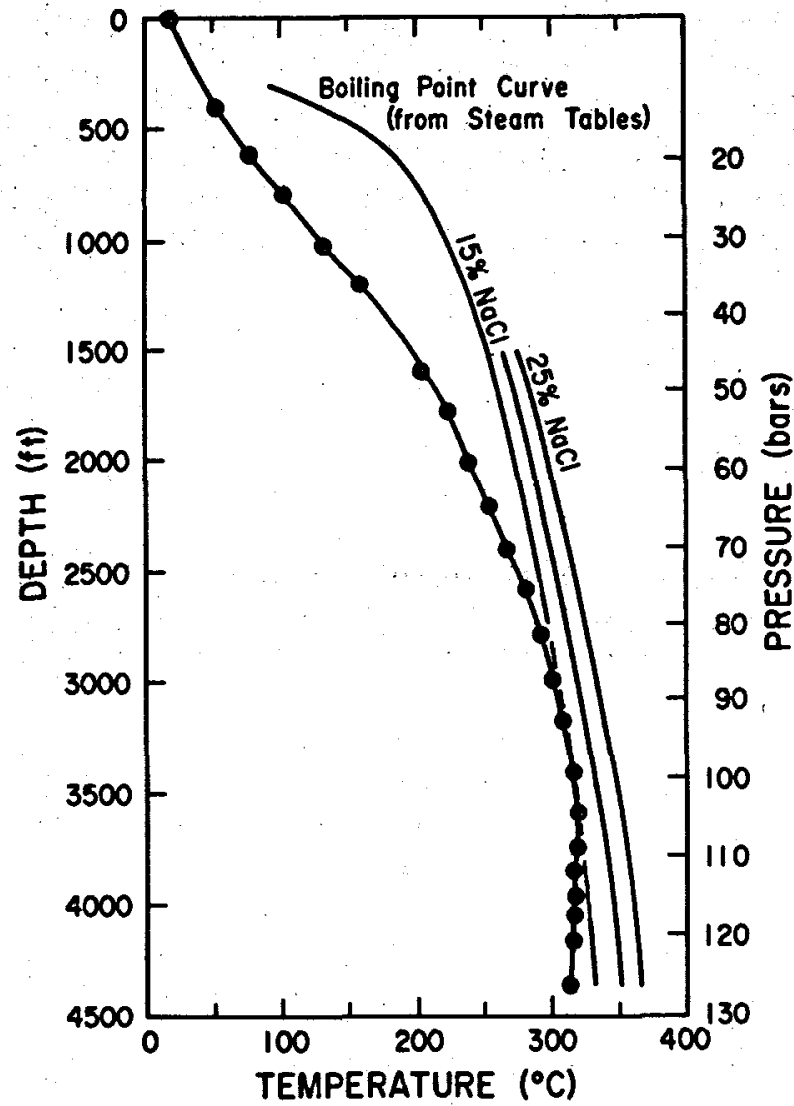

Figure 27. Present static temperature profile in Magmamax 2 plotted against the boiling curves for pure water and for 15 and 25 .wt. \% $\mathrm{NaCl}$ solutions (after Kenda11, 1976; temperature profile from Randal1, 1974; and the curves for the 15 and $25 \mathrm{wt} . \% \mathrm{NaCl}$ solutions, adjusted to the observed pressure gradient of .0287 bars/ft, are from Haas, 1971). detection of gamma rays; (2) a boiling zone where steam causes low $\rho_{\text {Bsd }}$; and (3) a clean sandstone aquifer: The inspection of the caliper log shows no evidence for enlarged boreholes at these depths. Next, a steam zone is highly unlikely since the temperatures at approximately $2000 \mathrm{ft}(610 \mathrm{~m})$ are insufficient to cause boiling for brine solutions at 15 or 20 wt. $\% \mathrm{NaCl}$ (Figure 27). Finally, a low-density, clean sandstone aquifer is the most plausible explanation. Using oxygen isotope minima, Kendall (1976) correlated'this horizon between wells Magmamax 2 and 3. Oxygen isotopic minima signify that high water to rock interactions have occurred. Hence, from these minima, Kendall (1976) postulated that this zone is a major horizontal aquifer. Consequently, marked low opsd readings within specific horizons as shown in Magmamax 2 and 3 within the chlorite zone may qualitatively indicate permeable zones within and between wells.

Typically maximum $\rho_{B s d}$ are located near the base of $\mathrm{B}$ the chlorite zone. These high $\rho_{\text {Bsd values may }}$ indicate that a types of self-sealed caprock may be forming. Examination of thin sections from this part of the well in Magmamax 2 and 3 shows low apparent porosity as demonstrated by filled pores of quartz-feldspar overgrowths and carbonate cement (S. D. McDowell, personal communication, 1982). 
The rise in $\rho_{\text {Bsh }}$ is generaliy cont junuous through the chlorite zone from approxinately $2.25 \mathrm{gm} / \mathrm{cm}^{3}$ to $2.60 \mathrm{gm} / \mathrm{cm}^{3}$. The rise in density is probably caused by an increase in quartz content with concomitant decrease in porosity and low density mixed layer clays.

In summary, the chlorite zone is characterized by an overall, rise in both Rsh and Rsd. Agradual increagse in $\rho_{B s d}\left(2.1 \mathrm{gm} / \mathrm{cm}^{3}\right.$ to $\left.2.4 \mathrm{gm} / \mathrm{cm}^{3}\right)$ and Bsh $\left(2.2 \mathrm{gm} / \mathrm{cm}^{3}\right.$ to $\left.2.6 \mathrm{gm} / \mathrm{cm}^{3}\right)$ al so occurs. The increase in concentration of authigenic chlorite and porosity reduction with depth appear to have the greatest effect on log responses. Drastic salinity changes within a well, however, may alter the Rsd curve which may cause errors in the correct identification of mineral zones on logs.

4. Feldspar Zone. Hydrothermal mineralogy has a dominant effect on well log characteristics within the feldspar zone. The high concentration of feldspars in shales correlates directly to Rsh values. Usually at the top of this zone, the Rsh values quickly rise by 0.4 to $0.8 \mathrm{ohm}-\mathrm{m}$ (Figure 28). This rise accompanies an increase in content of alkali and plagioclase feldspar from approximately $10 \%$ to $25 \%$ or greater in the shales. The feldspar concentration comes at the expense of fllite and the mixed layer clays. Induration of the shales and dehydration of the clays also occurs.

In well I.I.D. 2 (Figure 12), the log characteristics in a section of the feldspar zone differ from the other wells studied in this field.

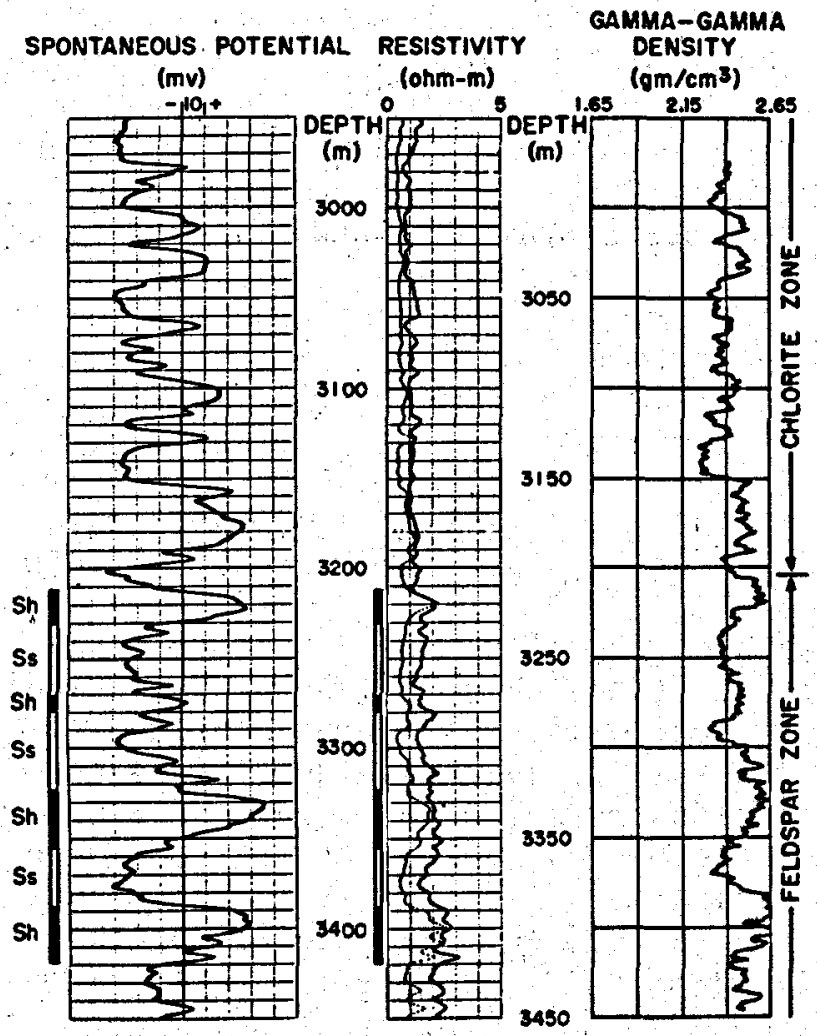
Generally, the Rsh increases rapidly with depth upon entering the feldspar zone; however, the Rsh decreases in this well. These low Rsh values occur between $2800 \mathrm{ft}(854 \mathrm{~m})$ to $4050 \mathrm{ft}$ (1235 ft) (Figure 12). S. D. McDowell (personal communication, 1981) states that in well I.I.D. 2 an unconsolidated zone in sandstones exists between the aforementioned depths. The sandstones in this zone are weakly cernented and consequently have high porosities in the range of $28 \%$ to $30 \%$ as determined from sidewall and solid core samples (McDowell, unpubl ished data; also see page 50). (Density, neutron, and sonic logs were not run for this well at the time it was drilled). Because of the unconsolidated nature of this zone, it is believed that the associated shales also have unusually high porosities for the feldspar zone. Hence, these low Rsh values may result from highly saline brines of approximately 250,000 ppm in this we11. Furthermore, the clays in this zone may have high cation exchange capacities which can cause low Rsh values. Below $4100 \mathrm{ft}$

Figure 28. An example of the high shale resistivities in the feldpar zone for well Magmamax 2. Sh $=$ shale and ss = sandstorie. 
(1250 m) (Figure 12), the Rsh increases dramatically to values normally associated with the feldspar zone.

From $2850 \mathrm{ft}(859 \mathrm{~m})$ to $3500 \mathrm{ft}(1067 \mathrm{~m})$, well Elmore 1 (Figure 13) displays similar log reponses to that observed in well 1.1.0.2 (Figure 12), where Rsh values are abnormally low for the feldspar zone. There are three possible explanations. One is that a young, unconsolidated zone similar to that found in well I.I.D. 2 is present. Confirmation of the existence of this zone is impossible because of the lack of porosity data from either wireline logs or cores. Another is that this interval is a "cold zone." Inspection of the static temperature profile for this well (Figure 6) shows no evidence for a temperature reversal. The shale mineralogy (Appendix 2), however, indicates an increase in calcite concentration (from $\sim 5 \%$ to $15 \%$ within this zone). (Shale mineralogy is not as reliable an indicator of present temperatures in a well as sandstone mineralogy because the reaction kinetics of mineral transformation are slower due to low permeability and porosity of the shales.) This increase may imply a slight temperature depression. Lastly, this zone consists predominantly of shale. (Figure 3, see lithology log). The lack of sandstones, a permeable medium, inhibits the hydrothermal fluids from interacting with the shales in this zone. The lack of interaction of the shales with the fluids may preserve a more pristine shale mineralogy. Therefore, the shale mineralogy may be in disequilibrium with the present temperatures, and the cation exchange capacity of the clays may not be destroyed. At present, this latter explanation appears to be the most plausible since the Rsh values and Rsd/Rsh ratio return to those normally associated with the feldspar zone below this interval (Figure 13).

At the chlorite zone/feldspar zone boundary, the Rsd decreases abruptly from $1-2 \mathrm{ohm}-\mathrm{m}$ to less than $0.5 \mathrm{ohm}-\mathrm{m}$. The drop in resistivity is probably due to an increase in formation water salinity. Mineral transformations that occur from the chlorite to the feldspar zone of the sandstones may release ions into solutions, thus increasing the formation water salinity (Muffler and White, 1969) and lowering the sand resistivity in the feldspar zone as compared to the chlorite zone.

The opsh within this zone typically increases from $2.40 \mathrm{gm} / \mathrm{cm}^{3}$ to 2.62 $\mathrm{gm} / \mathrm{cm}^{3}$. (Bshte that higher $\rho_{\text {Bsh }}$ values appear on Figures 10 and 11 , but these values are attributed to the Bresence of sflicic dike rocks. See section on Detection of Igneous Rocks, pages 33-34.) These high $\rho_{B s h}$ values are uncommon for shallow depths of $3000-4000 \mathrm{ft}(915-1219 \mathrm{~m})$ in areass of normal heat flow and recent sedimentation. For example, in the oil fields of the San Joaquin Valley in California, similar $\rho_{B s h}$ values occur at depths greater than $12,000 \mathrm{ft}$ (3658 m) (Seamount, 1981).

The opsh values in the feldspar zone are generally more uniform and have density values similar to the lower portions of the chlorite zone. Deviations from these trends occur as $\rho_{\text {Bsd }}$ is higher, hence, probably more indurated.

In conclusion, the main exfects on resistivity in the feldspar zone come from large, authigenic concentrations of feldspars in shales. In sandstones, salinity increases possibly caused by release of ions in the transformation of the chlorite mineralogy to the feldspar mineralogy chiefly aids in the reduction of Rsd. The Rsh normally rises by $0.4 \mathrm{ohm}-\mathrm{m}$ to $0.8 \mathrm{ohm}-\mathrm{m}$ at the top of this zone, and the $\rho_{\text {Bsh }}$ can increase from $2.4 \mathrm{gm} / \mathrm{cm}^{3}$ to $2.62 \mathrm{gm} / \mathrm{cm}^{3}$ The Rsd js typically less than $0.5 \mathrm{ohm}-\mathrm{m}$ with $\rho_{\text {Bsd }}$ between $2.35 \mathrm{gm} / \mathrm{cm}^{3}$ to $2.55 \mathrm{gm} / \mathrm{cm}^{3}$. The Psh values are higher than those nofindly expected from compaction alone.

B. The Westmorland Geothermal Field

In the study of four Westmorland geothermal wells, only Kalin Farms 1

(Figure 18) displays log responses characteristic of the mineralogic zones 
defined by shale $x$-ray diffraction data. These log responses are similar to those found in the SSGS; hence, only a brief discusison of the reponses will be given. An explanation of the different log characteristics in this field will then follow.

In well Kalin Farms 1 (Figure 18), only the montmorillonite, the illite, and the chlorite mineralogic zones are present. Within the montmorillonite zone, Rsd and Rsh values vary, and below $2000 \mathrm{ft}(610 \mathrm{~m})$ the Rsh is consistently less than Rsd. The alignment of clay particles and resultant expulsion of water from the interlayers of the clays through compaction probably causes the Rsh to become less than Rsd. The top of the filite zone is distinguished by a 0.5 ohm $-m$ rise in Rsh. This increase is attributed to approximately $4 \%$ loss in the effective clay, montmorillonite (Appendix 2). (The percentage referred to relates to total bulk rock composition) The Rsh values in this zone fluctuate tremendously and possibly result from varying degrees of cementation as suggested by the lack of dolomite and ankerite in low resistivity zones. The transition into the chlorite zone is identified by a nearly parallel rise in both Rsd and Rsh curves, although Rsd shows large fluctuations. A $4 \%$ increase in chlorite content accompanied by a $1 \%$ rise in illite concentration contributes to the Rsh rise. (The percentages referred to relate to total bulk rock composition.) The Rsd rise most likely results from an increase in feldspar and quartz content together with a decrease in porosity.

In comparison, difficulties arise in correlating log responses to mineral zones in shales in wells Landers 1 (Figure 17), Landers 2 (Figure 20), and Dearborn Farms 1 (Figure 19). The examination of the shale $x$-ray diffraction data for lower portions of those wells suggests an illite zone mineralogy. (Appendix 2); however at approximately $5500 \mathrm{ft}(1676 \mathrm{~m}), 6300 \mathrm{ft}(1920 \mathrm{~m})$, and $7600 \mathrm{ft}(2317 \mathrm{~m})$ : in wells Landers 1 and 2 and Dearborn Farms 1 , respect ively, apparent chlorite zone log responses are signaled by an overall rise in Rsh. The rise in Rsd is probably not seen because of a change in water salinity (see pages 39-44). In these cases, the rise in Rsh is presumably related to greater induration of the sediments and/or to less conductive clay minerals in the lower portions of this well.

From detailed study of these wells, discrepancies are found to exist between measured, isotopic, and log mineral-zone-derived temperatures. According to static temperature profiles, well Landers 1 is hotter than well Kal in Farms 1 (Figure 29). Yet, isotopic temperatures calculated using the falcite most nearly in isotopic equilibrium (1ightest $\delta^{18} 0$ ) and the water $\delta^{18} 0$ for each well show that Kalin Farms 1 is considerably hotter than Landers 1 (01son and Matlick, 1977, from Table 3):

\begin{tabular}{|c|c|c|c|}
\hline & & Temper & $\left({ }^{\circ} \mathrm{C}\right)$ \\
\hline Well & Depth Sampled & Measured & Isotopic* \\
\hline $\begin{array}{l}\text { Landers } 1 \\
\text { Kal in Farms } 1\end{array}$ & $\begin{array}{l}6880 \mathrm{ft}(2097 \mathrm{~m}) \\
7115 \mathrm{ft}(2196 \mathrm{~m})\end{array}$ & $\begin{array}{l}227 \\
216\end{array}$ & $\begin{array}{l}165 \\
259\end{array}$ \\
\hline
\end{tabular}

Furthermore, estimate of temperatures from the 111 ite-chlorite mineral zone transition indicates well Kal in Farms 1 had temperatures greater than $230^{\circ} \mathrm{C}$. The illite zone mineralogy of well Landers 1 signifies temperatures less than $230^{\circ} \mathrm{C}$.

\footnotetext{
*Calculated using the equation $10^{3} \ln _{\mathrm{H}_{2} \mathrm{O}}^{\mathrm{Ct}}=2.78 \times 10^{6}\left(\mathrm{~T}^{-2}\right)-2.89$ where $T=$ temperature $\left({ }^{\circ} \mathrm{C}\right)\left(0^{\prime} \mathrm{Ne}\right.$ i) et ${ }^{2}$ al., 1969; modified by Friedman and $0^{\prime}$ Ne il, 1977).
} 


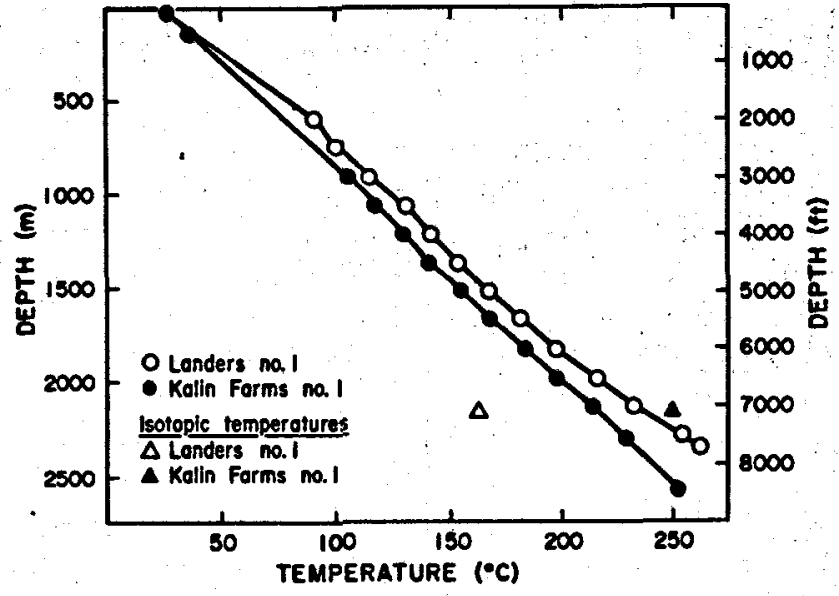

Figure 29. Comparison of temperature data for wells Landers 1 and $\mathrm{Kal}$ in Farms 1. Isotopic temperatures are from 01 son and Matlick (1978).
There are two possible reasons to explain the above disagreement. First, the static temperature profiles, the reported best representative temperatures for these wells ( $C$. Isselhardt, personal communication, 1981), are inaccurate. Second, if the static temperature profile reflects present conditions, the recorded isotopic temperatures could be the result of prior thermal regimes. Therefore, this argues that well Landers 1 is presently heating up, and well Kalin Farms 1 is cooling. Moreover, the comparison of sandstone and shale $x$-ray diffraction data between each well further substantiates the latter agreement (Appendices 2 and 3 ). The shale $x$-ray data clearly show Kalin Farms 1 is hotter than Landers 1 by the disappearance of the minerals dolomite, ankerite, kaolinite, mixed layers, and siderite. As stated previously, shale mineralogy may not reflect present conditions in a well. Thus, sandstone $x$-ray diffraction data were compared. The indication is that Kalin Farms 1 is slightly hotter than Landers 1. This argument also assumes that the original detrital content of the sediments for both wells is basically the same. From the data presented it appears that well Landers 1 is heating up while Kalin Farms 1 is cooling.

C. Problems in the Delineation of Mineral Zones on Logs

Even though mineral zones are delineated in most cases on wireline logs by log signatures, physical characteristics of the reservoir which affect $10 \mathrm{~g}$ responses may occasionally mask mineral zone boundaries. Figure 30 shows a cross section through the SSGS displaying the mineralogic zones of shales

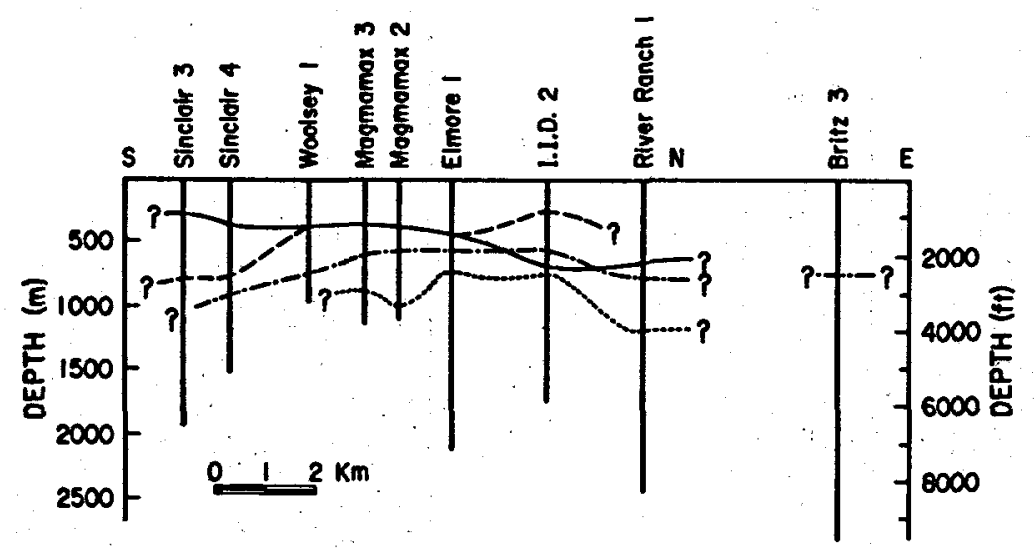

Figure 30. A cross section through the Salton Sea geothermal field depicting the mineral zones of selected wells to the general stratigraphy of the subsurface. Base of zones derived almost exclusively from $x$-ray examination of cuttings (Appendix 2). 
defined in this report. As depicted on this diagram, the montmorilionite zone can be either entirely within the lacustrine sequence or in the interstratified sandstone and shale portion of the reservoir. In the former case, the boundary between the montmorillonite and illite zone is difficult to locate in that the lacustrine sequence generally shows faiply constant resistivity response throughout, and only a single lithology (shale) is normally present (Figures 10-13). In order to circumvent the difficulties in defining the montmorillonite-1llite zone boundary within the lacustrine sequence, the boundary was placed at the interface of the lacustrine and sandstone-shale deltaic sequence for wells Magmamax 2 and 3 and Elmore 1 . This boundary is easily recognized on well logs. It has been shown that the montmorillonite-illite zone boundary can be located within the intercolated sandstone-shale sequence of the field (Figures 14-15).

Portions of the illite and chlorite zone can also be present within the lacustrine sequence. As in well I.I.D. 2 (Figure 12), the differentiation of these zones is possible on logs because of the presence of sand bodies within the lacustrine sequence. This gives Rsd and Rsh curves upon which mineral zone determinations can be made.

As stated previously, a high resistivity zone due to the presence of a resistive mineral such as anhydrite 1 ies between 6400-7500 ft (1951-2286 $\mathrm{m}$ ) in well Britz 3. The high resistivities may lead to errors in interpreting mineral zone boundaries. Consequently, close scrutiny of lithologic logs is mandatory in order to be cognizant of high concentrations of resistive minerals.

Major salinity changes in a well may also cause problems in delineating mineral zones. In well Sinclair.4, a divergence in sandstone and shale resistivity values occurs at approximately $4100 \mathrm{ft}(1250 \mathrm{~m})$ (Figure 14). This divergence, the result of a drop in Rsd due to an increase in water salinity, is simflar to that found at the top of the feldspar zone; however, temperatures and shale mineralogy indicate the chlorite mineralogic zone. If drastic changes in formation water salinity are not taken into account, misinterpretation of $10 \mathrm{~g}$ data may result. Furthermore, salinity changes in well Landers 1 (Figure 17) have hindered mineral zone identification by $10 \mathrm{~g}$ responses (see pages 41-43).

D. Detection of Igneous Rocks

Subsurface igneous rock has been reported from four wells in the SSGS: Magmamax 2, Magmamax 3, I.I.D. 2, and Elmore 1 (Robinson et al ., 1976; Randall, 1974; McDowell and Elders, 1980). Robinson et al. (1976) have divided these subsurface igneous rocks into two groups based on chemical and petrologic data: (1) dark-gray to black, fine-grained to porphyritic basalt; and (2) light-gray, fine-to medium-grained silicic rock. These subsurface rocks are belleved to be the result of intrusion of dikes.

In well Magmamax 3, Randa11 (1974) reported the presence of 10 zones of silicic dike rocks each up to $10 \mathrm{ft}(3 \mathrm{~m})$ thick between $3591-4000 \mathrm{ft}$ $(1095-1220 \mathrm{~m})$. He based his findings on drill cutting examination and electric log interpretation. A more detailed log evaluation of these dike rocks will be given.

These silicic dike rocks have certain log characteristics similar to sandstones (Figure 31 ). The natural gamma-ray count for these dike rocks is approximately 75 API units. In comparison, the sandstone baseline at these depths is approximately 55 API units. This relationship for a sediment would be a shaly sandstone. On the other hand, the dike rocks have some shale characteristics, such as an SP deflection toward the shale baseline and densities as high as $2.7 \mathrm{gm} / \mathrm{cm}^{3}$. But the resistivities are abnormally high (between $3.0 \mathrm{ohm}-\mathrm{m}$ to $4.7 \mathrm{ohm}-\mathrm{m}$ ) for shales. Consequently, these silicic dike rocks are 


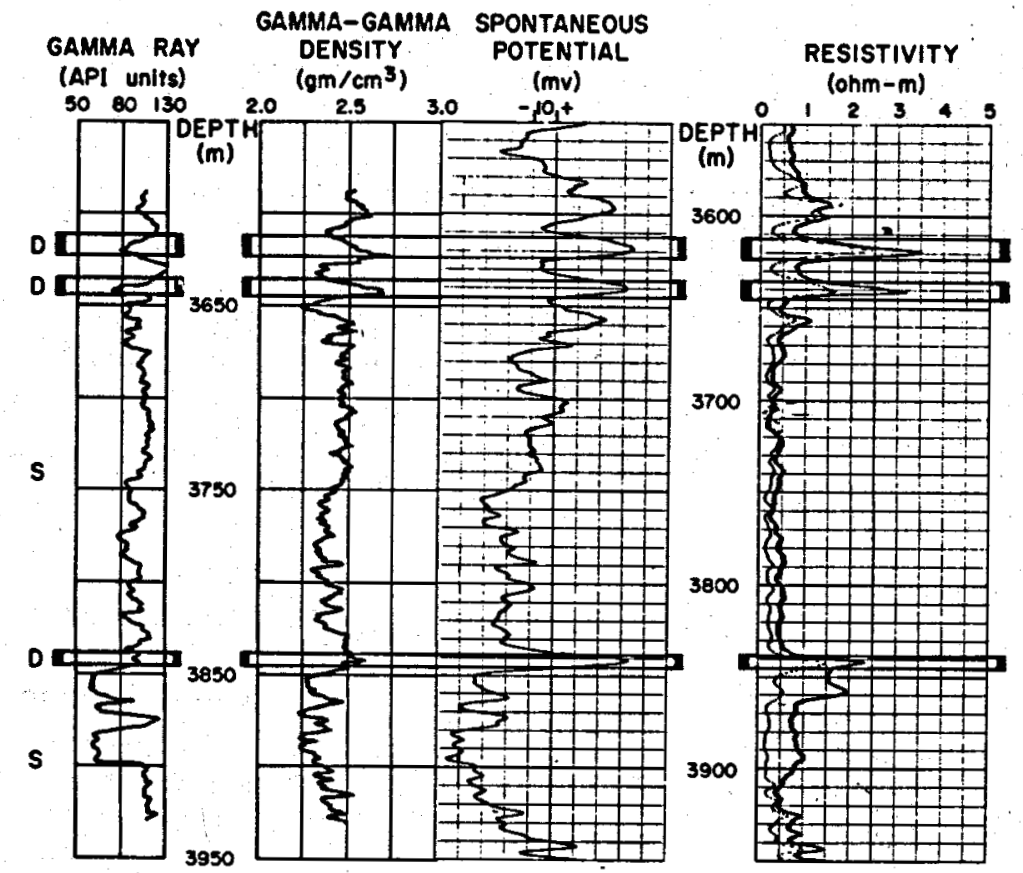

Figure 31. Dike rock iocations and characteristics in well Magmamax 3 (data from Randal1, 1974). $\mathrm{D}=$ dikes; $\mathrm{S}=$ sediments.

characterized by high resistivity, relatively high radioactivity (Adams, 1954; Barsukov et al., 1965), and high density. Probable dike rock locations in well Magmamax 2 are shown in Figure 10.

The identification and characterization of the basaltic dike rock found in well I.I.D. 2 (Robinson et al., 1976) based solely on electric log information is fortuitous at best. Additional log data such as gamma-gamma density is needed for a more unequivocal interpretation.

\section{USE OF THE EMPIRICAL RELATIONSHIPS TO IDENTIFY MINERAL ZONES ON LOGS}

In order to test the empirical relationships developed in this study, a total of seven additional wells from the SSGS were scrutinized. These wells, listed below, are from diverse locations within the field (Figure 2):

\section{Well}

River Ranch 1

State of California 1

Magmamax 1

Woolsey 1

Sinclair 1

I.I.D. 1

Sportsman 1
Operator

Union Dil Co.

Shell 0 il $\mathrm{Co}$.

Magma Power Co.

Magma Power Co.

Kent Imperial Co.

J. I. O'Neill, Jr.

J. I. O'Neill, Jr.

The characteristic log responses, previously elaborated upon in detail (see pages 24-30), are used to identify mineral zones in each of these wells (Figures 32-38). In summary, the montmorillonite zone is characterized by fairly constant Rsd and Rsh responses. The transition into the illite zone is marked 


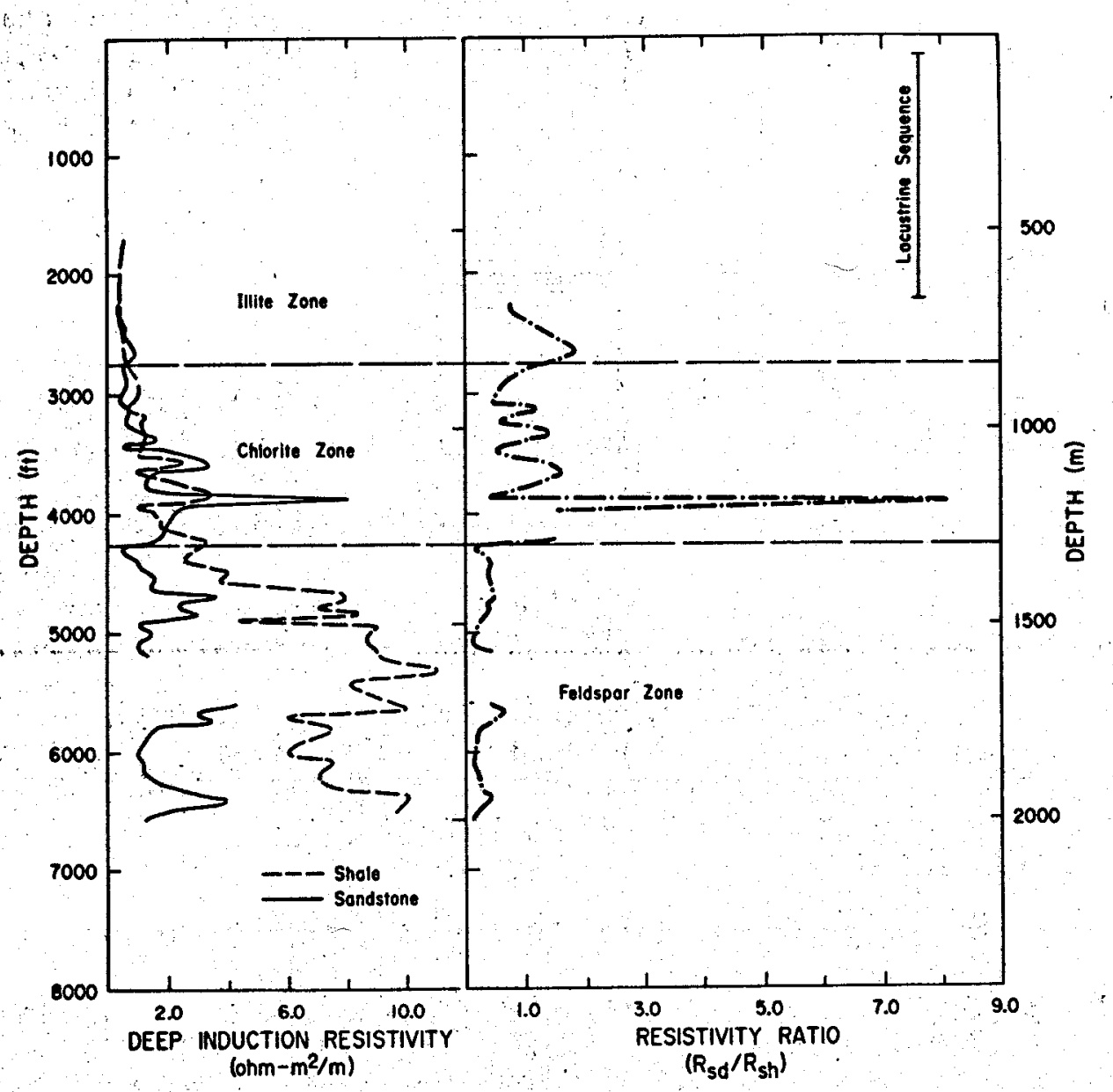

Figure 32. Well River Ranch.1, well log data vs. depth. 


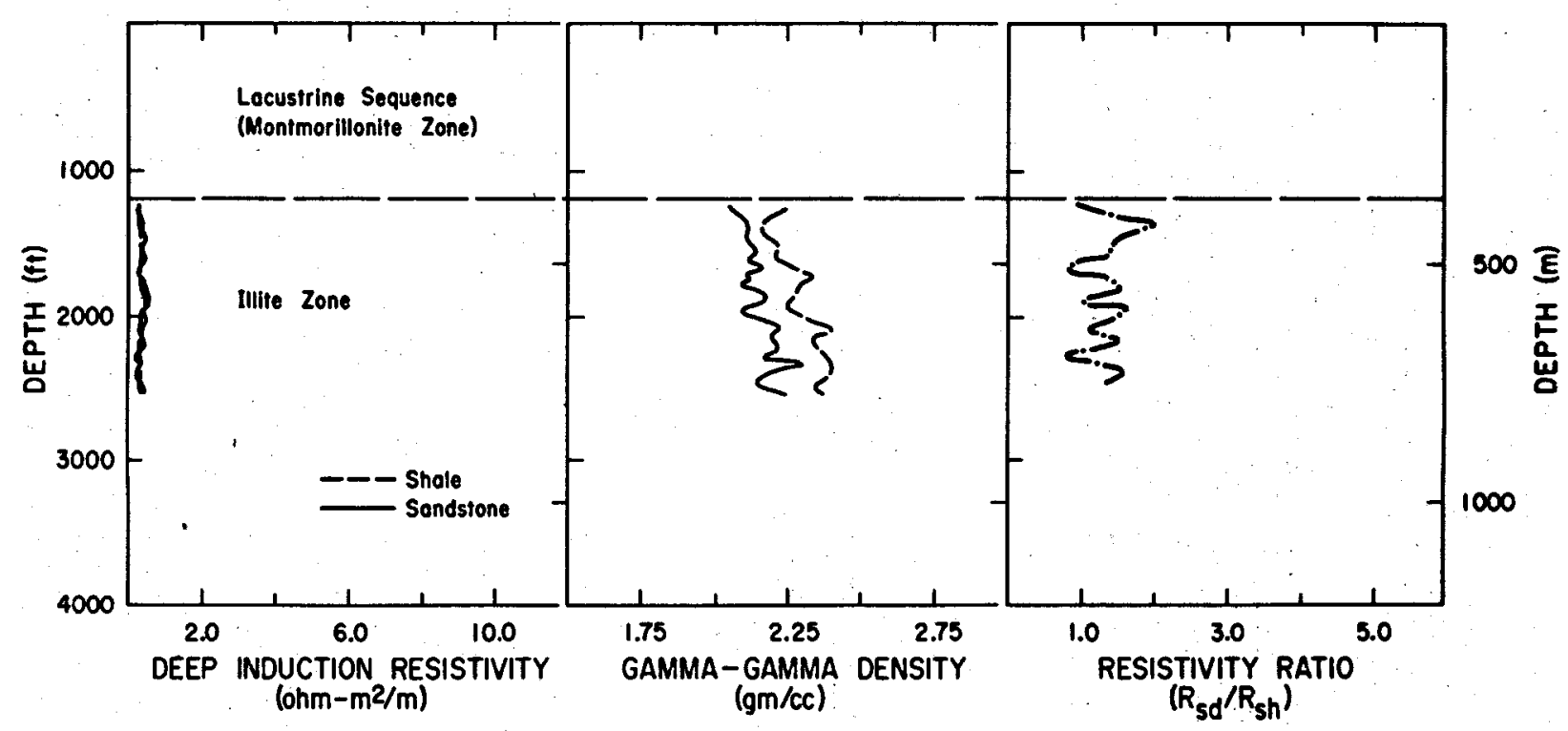

Figure 33. Well Magmamax 1, well log data vs. depth.

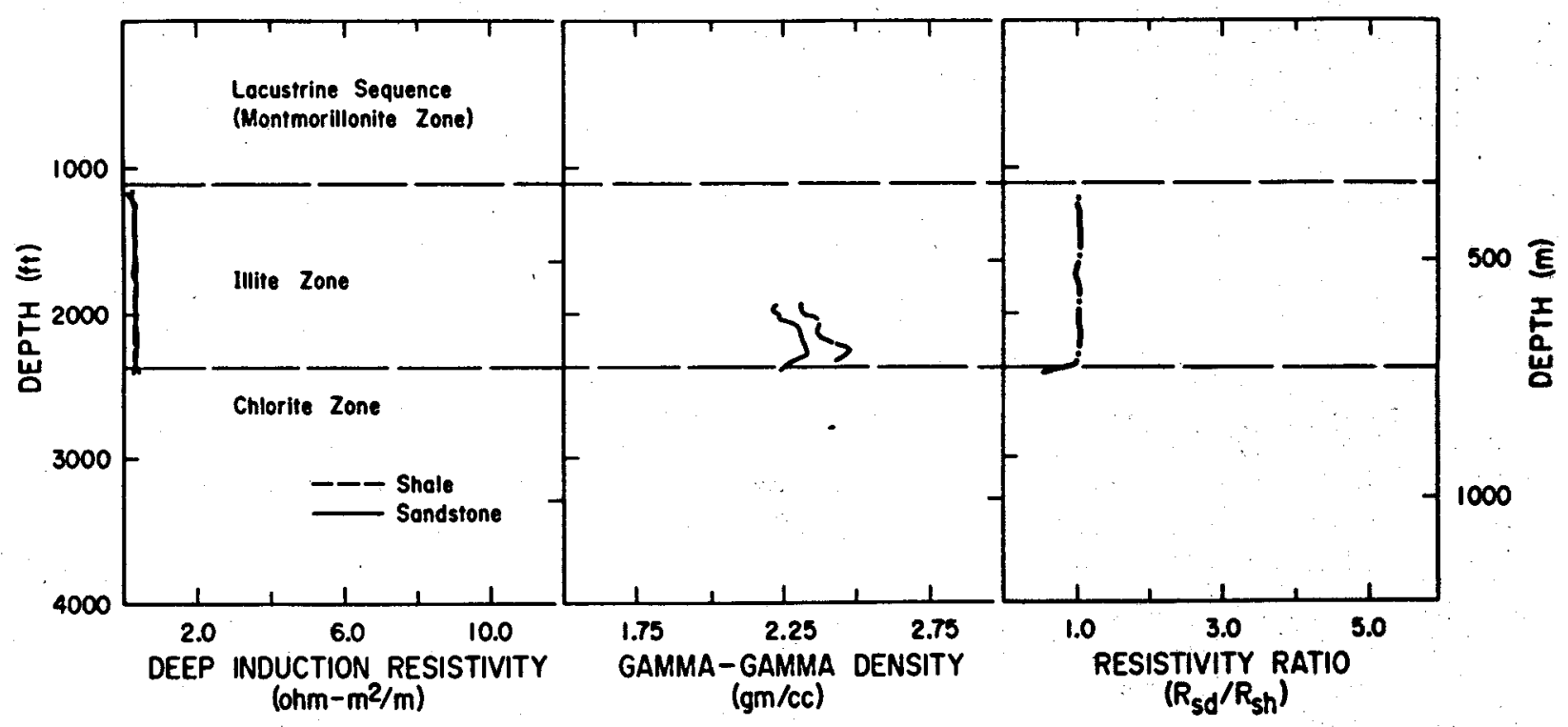

Figure 34. Well Woolsey 1, well log data vs. depth. 


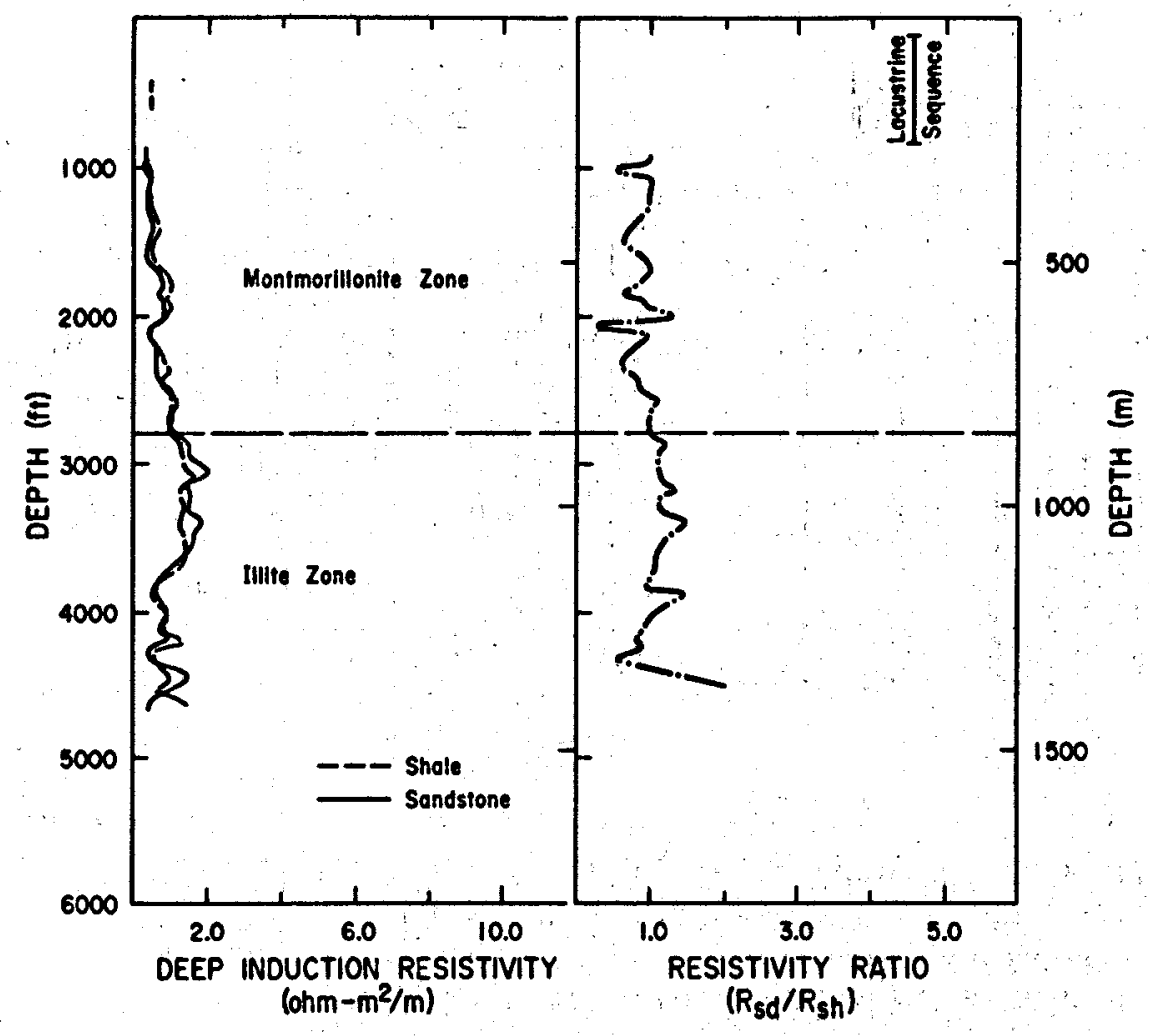

Figure 35. Well Sinclair 1 , well log data vs. depth.

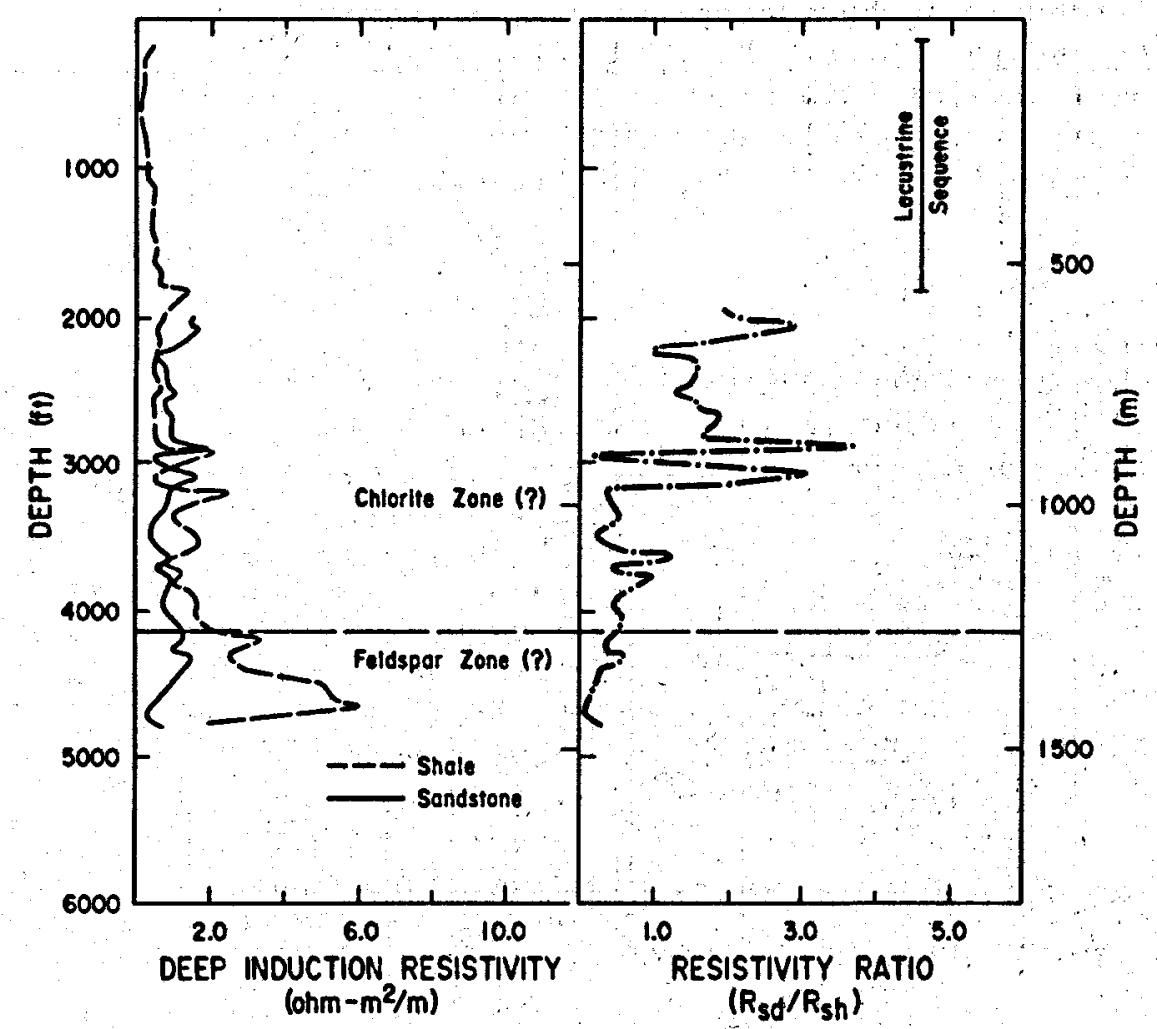

Figure 36. Well State of California 1 , well log data vs. depth. 


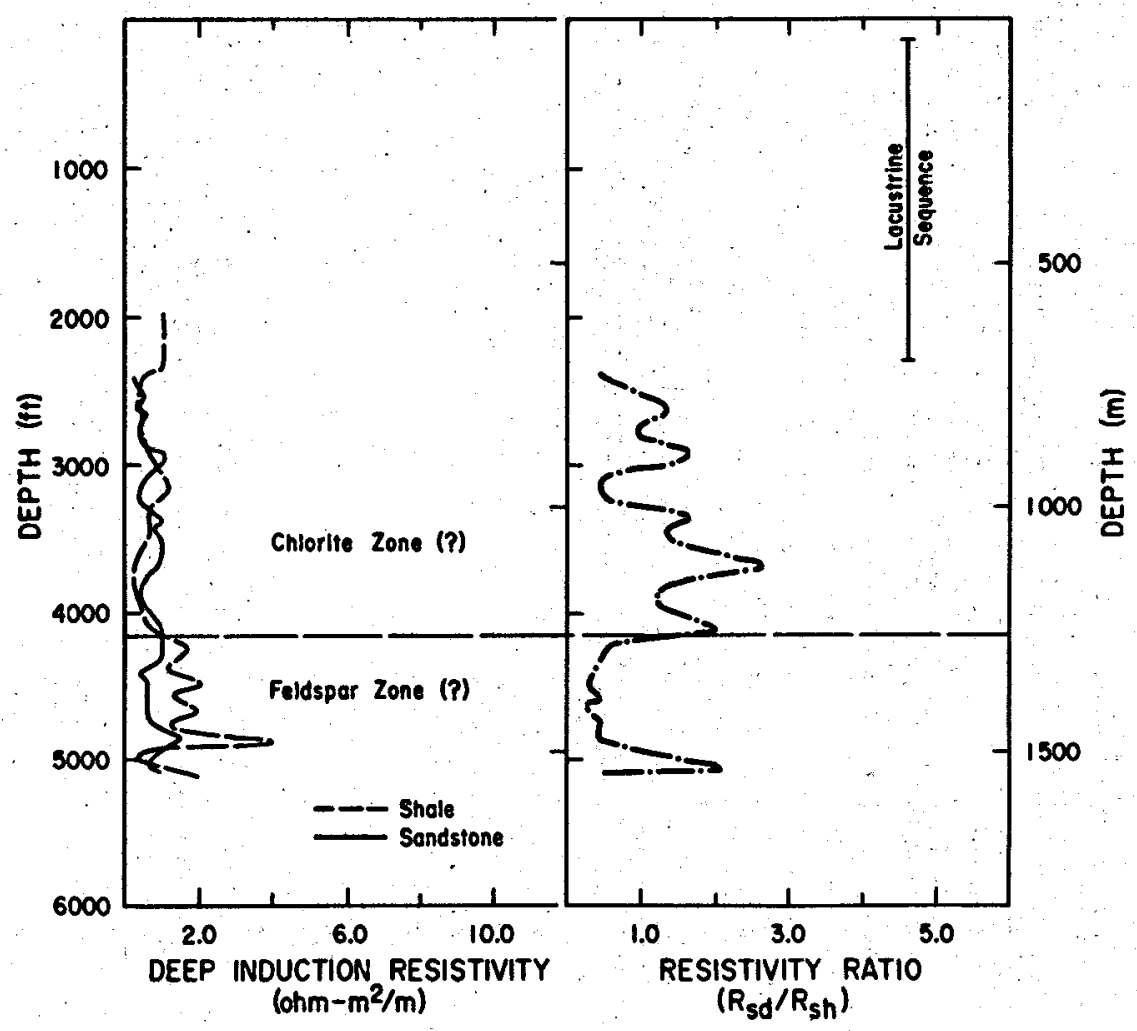

Figure 37. Well I.I.D. 1, well log data vs. depth.

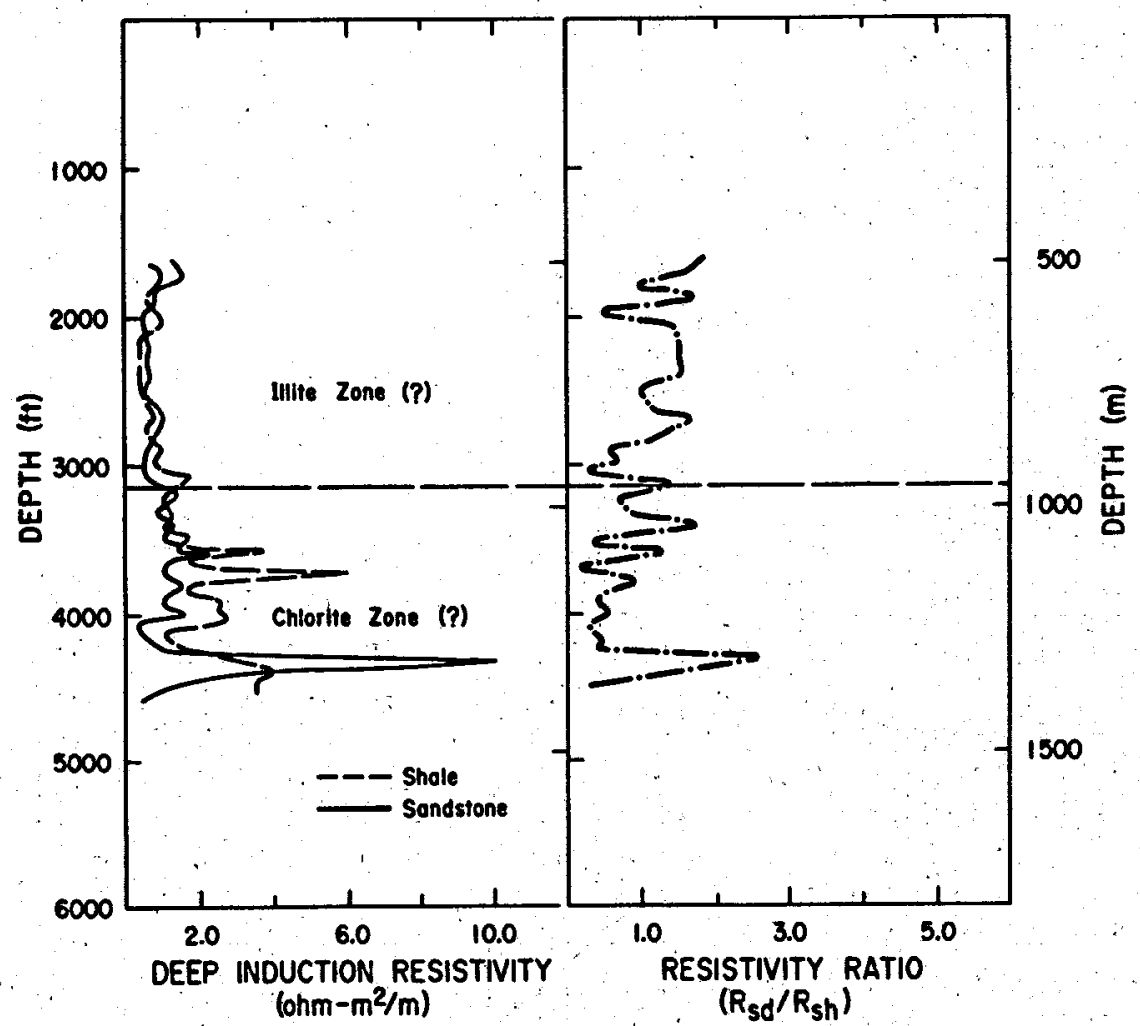

Figure 38. Well Sportsman 1, well log data vs. depth. 
by slight rise in Rsh caused by the loss of the effective clay, montmorillonite. The resistivity response of both sandstone and shale is fairly constant within this zone. A nearly parallel rise in both Rsd and Rsh signals the entrance into the chlorite zone. Lastly, the top of the feldspar zone is demarcated by the divergence in Rsd and Rsh curves with the sandstone resistivity decreasing and the shale resistivity increasing rapidly. In order to verify the interpreted mineral zones from $l 0 g$ responses, shale $x$-ray diffraction data for one well, River Ranch 1, were generated, but other $x$-ray data in existence were also used.

Figure 32 shows the interpreted mineral zone boundary locations from log responses for well River Ranch 1. Note the $\log$ responses for both Rsd and Rsh fluctuate greatly within the chlorite zone. Inspection of the shale $x-$ ray diffraction data for this well (Appendix 2) shows that between 2843-3880 ft (867-1183 m) ànomalously high alkali feldspar concentrations are present. Also, 111 ite and chlorite are extremely depleted. In addition, the sandstones are extensively altered in this zone (Cox, 1977). An explanation for the unusual mineral contents is difficult to make without supplementary density, porosity, and petrologic data. In any case, if the anomalously high alkali feldspar concentrations are disregarded, the shale $x$-ray diffraction data substantiate the interpreted zone boundaries.

The interpretation of wells Magmamax 1 (Figure 33), Woolsey 1 (Figure 34) (shale $x$-ray diffraction data for this well substantiates the interpreted zone boundary locations - see Appendix 2), and Sinclair 1 (Figure 35) is rather straightforward and has been aided by the similarity in log responses to other nearby wells. Wells State of California 1 (Figure 36), I.I.D. 1 (Figure 37), and Sportsman 1 (Figure 38 ) do not show the same systematic log responses. The absence of sharp contrasts in physical properties of the rocks in the northeast fringes of the field is a likely cause of these uncharacteristic log responses. In order to locate these mineral zones within these wells more accurately, porosity and/or density data are needed.

\section{LOG-DERIVED SALINITY}

Estimation of salinity profiles in geothermal wells is important in planning well completions, subsurface mapping, and environmental impact considerations (Gobran et al., 1981). Moreover, because of the marked effects that salinity has on resistivity and, hence, interpretation of log data, attempts have been made to estimate salinity from well logs. Only wireline logs from the WGS were studied rather than attempting to do so in the SSGS with its extremely high temperatures and hypersaline fluids. In addition, the wireline logs from the Westmorland area are more modern, are of good quality, and have accurate records of drilling mud types and properties.

Two methods primarily used in the petroleum industry to estimate $R_{w}$, the resistivity of the formation water, from well logs have application in sedimentary-type geothermal fields. These are an analysis of the spontaneous potential (SP) curve and the interpretation of sandstone resistivity and porosity data (Littleton and Burnett, 1975, 1977; Ershaghi et al., 1979). The following is a brief synops is of the methods used in this study to determine the formation water salinity.

The SP curve method entails use of the equation

$$
S S P=-K \log _{10}\left(\frac{a_{w}}{a_{m f}}\right),
$$


where $a_{w}$ and $a_{m f}$ are respectively the activities of the formation water and the mud filtrate, $K$ is a function of temperature $\left(K=60+0.133 T\right.$, in ${ }^{\circ} \mathrm{F}$; Dresser Atlas, 1977), SSP is the static spontaneous potential [millivolts (mv)]. For brines below $60,000 \mathrm{ppm}$, the activities are inversely proportional to their respective resistivities (Schlumberger, 1972; Ershaghi et al ., 1978):

$$
S S P=-K \log _{10}\left(\frac{R_{m f}}{R w}\right)
$$

$R_{W}$ can then be easily found if $R_{m f}$ at formation temperature* is known, together with the magnitude of the SSP:

$$
R_{W}=\left(R_{m f}\right) 10\left(\frac{S S P}{K}\right)
$$

A second method combines electric and porosity $\log$ data to determine $R_{\text {w. }}$ Archie (1942) showed that the formation resistivity factor, $F$, may be computed by the following empirical relationship

$$
F=\frac{a}{\phi^{m}}=\frac{R_{0}}{R_{W}},
$$

where a and $m$ are lithology-dependent parameters, $\phi$ is porosity, $R_{0}$ is the resistivity of a nonshaly formation $100 \%$ saturated with brine of resistivity $R_{W}$. If $R_{0}$ is obtained from a deep investigating tool, $\phi$ from porosity logs, and for this study $a=0.81$ and $m=2$ (Schlumberger, 1972), then $R_{w}$ may be calculated by

$$
R_{W}=\frac{\left(R_{0}\right)\left(\phi^{2}\right)}{.81}
$$

Another method employs the resistivity of the flushed zone, $R_{x o}$, and the true resistivity of the formation, $R_{t}$. Appendix 5 (Bateman and Konen, 1977b) shows a summary of the equations used in the computation to obtain $R_{t}$ and $R_{x o}$. Thus,

$$
R_{W}=\left(\frac{R_{t}}{K_{x 0}}\right) R_{m f} \text { (variables defined previously). }
$$

\footnotetext{
*Arps equation (Arps, 1953) corrects

resistivities at a given temperature to

those at another temperature. For example, $R_{m f_{2}}=R_{m f_{1}}\left[\frac{T_{1}+6.77}{T_{2}+6.77}\right]$
} 
After Rw is obtained from the above methods, the total dissolved solids (TDS) in equivalent sodium chlorite concentration can be found by applying the following equations:

For salinity data at $75^{\circ} \mathrm{F}\left(23.9^{\circ} \mathrm{C}\right)$,

$$
\mathrm{NaCl}_{\text {eq }}=10^{\mathrm{x}}
$$

(Bateman and Konen, 1977a)

where $x=\frac{3.562-\log _{10}\left(R_{75}-0.0123\right)}{0.955}$

and $R=R_{T}\left[\frac{T+6.77}{75+6.77}\right]$

For salinity data at formation temperature $\left({ }^{\circ} \mathrm{F}\right)$,

$$
\mathrm{NaCl}_{\mathrm{eq}}=\mathrm{y}^{1.05}
$$

(Bateman and Konen, 1977a)

where $y=\frac{300,000}{R_{W_{T}}(T+7)-1}$.

To calculate $R_{w}$ from the above methods, borehole temperatures which were acquired from the bottom-hole temperature recorded on the $10 \mathrm{~g}$ heading and deep formation temperatures obtained from temperature logs were used separately as estimates of the formation temperatures. However, the formation temperatures used in the computation of salinity on Figures 39-41 are from temperature logs (Figure 29 and Appendix 6) since the computed salinities are in closer (but still poor) agreement with the actual salinities; as explained below.

\section{A. Application to the Westmorland Wells}

Figures 39-41 are the salinity profiles generated by the above methods (see Appendix 6 for a summary of the data used in the salinity calculations). Also indicated on these figures are the actual sal inities determined from chemical analyses of the well fluid and the location of the sampling interval. Clearly, a lack of agreement between the well fluid analyses and log-derived salinities is evident. The log-derived salinities are lower than the actual salinities. This probably results from several factors. First, Equations 2, 5, and 6 are 


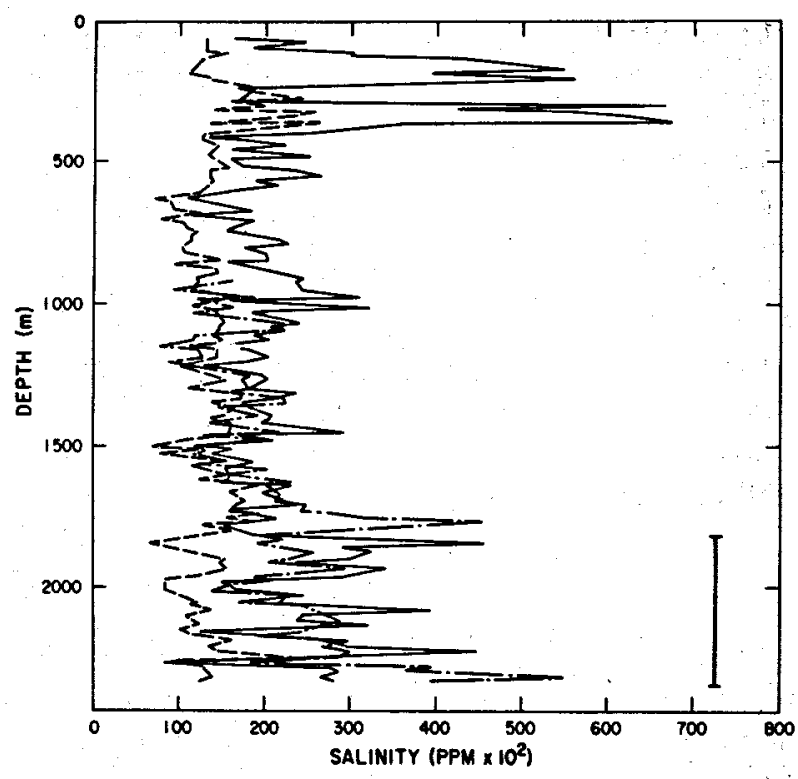

Figure 39. Log-derived salinity profile for well Landers 1 at $75^{\circ} \mathrm{F}\left(23.7^{\circ} \mathrm{C}\right)$.

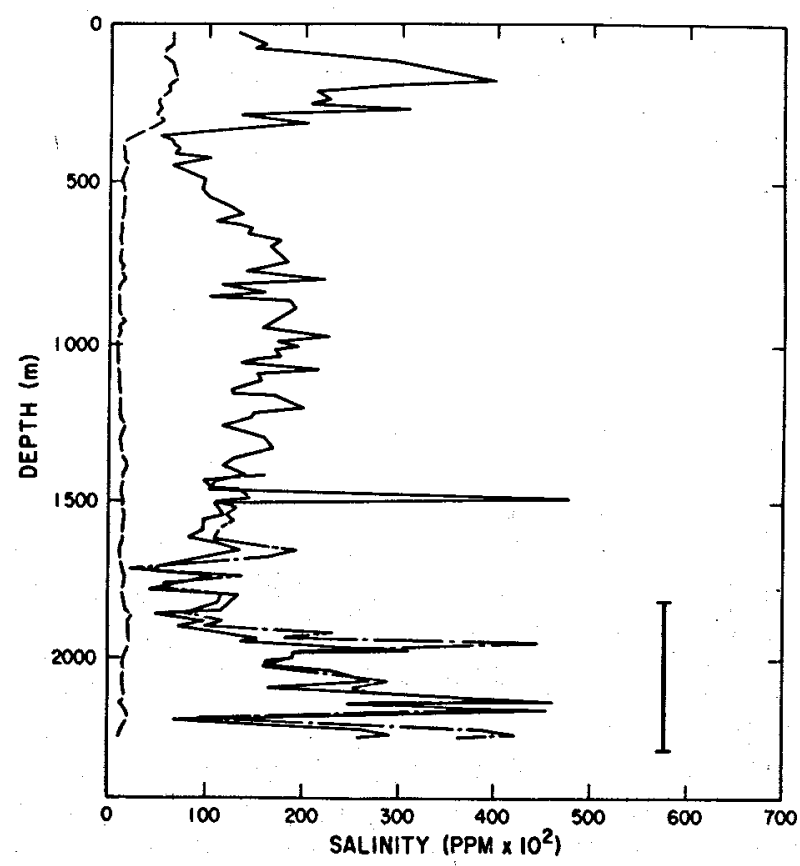

Figure 41. Log-derived salinity profile for well Dearborn Farms 1 at $75^{\circ} \mathrm{F}$ $\left(23.7^{\circ} \mathrm{C}\right)$.

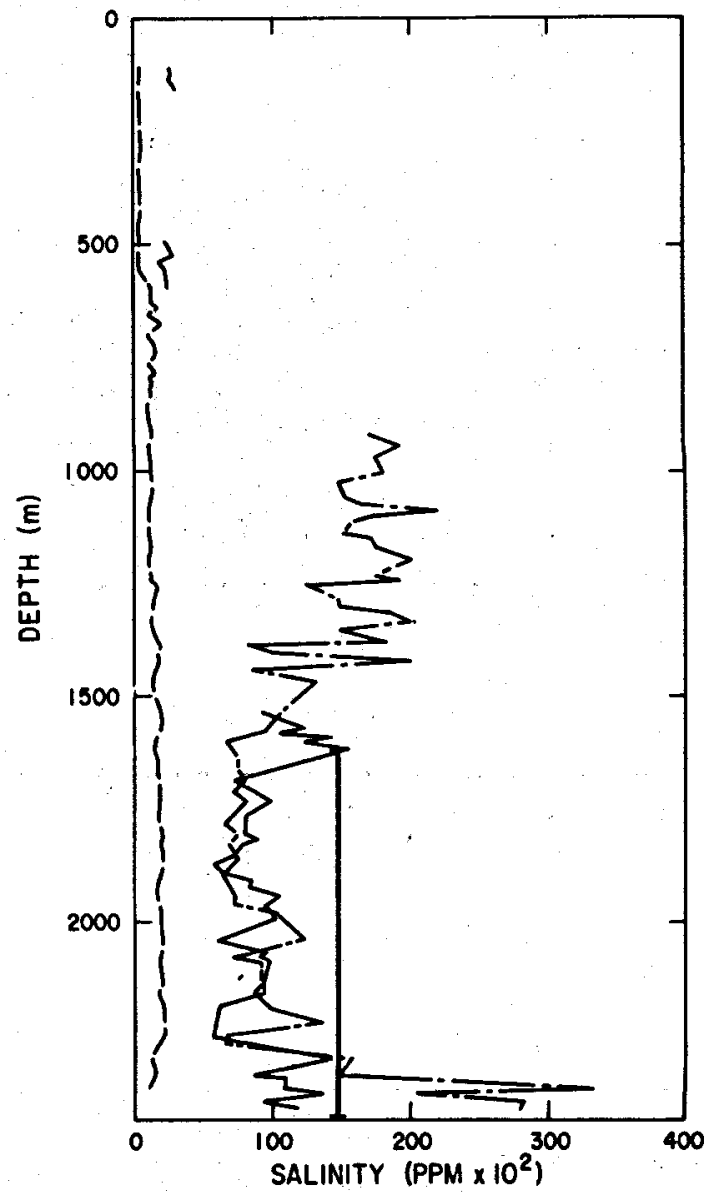

Figure 40. Log-derived salinity profile for well Landers 2 at $75^{\circ} \mathrm{F}\left(23,7^{\circ} \mathrm{C}\right)$. 
empirical relationships developed for petroleum fields to obtain Rw; hence, these equations may be invalid for use in sedimentary-type geothermal systems where high temperatures and hydrothermally altered sediments are encountered. For example, the constants used in Equation $5, a=0.81$ and $m=2$, apply in the shallower portions of the wells but are probably erroneous in the more hydrothermally altered sections. Second, the true $R_{m f}$ and $F_{m}$ at formation temperature are not accurately known. Ershaghi et al. $(1979,1981)$ state that the log-heading values of $R_{m f}$ and $R_{m}$ are probably unreliable due to likely changes in mud or mud filtrate characteristics. These changes result from extreme conditions in the borehole. Third, there are problems in determining the magnitude of the SP deflection (Equation 2), i.e., in several of the wells studied, shifts in shale baseline and streaming potentials made accurate estimation of the SP magnitude difficult. Furthermore, at elevated temperatures the validity of the magnitude of the SP deflection is questioned (Ershaghi et al., 1978).

Detailed examination of Figures 39-41 shows that the SP-derived salinity curves are consistently lower in value than the other curves. This occurrence is difficult to explain; however, a reduction in magnitude of the SP can result if the reference electrode is attached to the survey cable instead of being placed in the mud pit at the surface, which is the common practice (M. Mathews, personal communication, 1982). This procedure may alter the SP and, hence, $R_{W}$ appreciably.

Even though discrepancies exist between the log-derived and actual downhole salinity, the trend of the log-derived salinity data barring the SP-derived salinity data in this case is believed to mirror the actual downhole salinity. For example, in well Landers 1 (Figure 38) the salinity appears to increase at approximately $5300 \mathrm{ft}(1423 \mathrm{~m})$. This apparent rise in salinity may explain the low-sandstone resistivities in this zone (Figure 17).

The lack of agreement between actual and log-derived salinity has deterred the use of a resistivity-salinity crossplot. This crossplot should in principle correct sandstone resistivity for changes in formation water salinity.

Figure 42 displays the actual brine concentrations encountered in several wells of the SSGS and WGS (Helgeson, 1968; California Department of Water Resources, 1970; 01 son and Matilick, 1977; Needham et al., 1980; Republic Geothermal, Inc., personal communication, 1981. Note that the brine concentrations are corrected for steam loss). As shown on this figure, high-brine salinities are present in the central portion of the SSGS, while on the flanks. the brines are less concentrated.

\section{RESERVOIR POROSITY}

An, important aspect of reservoir analysis in sedimentary geothermal fields is the determination of porosity. In the SSGS previous petrographic studies have shown that a reduction in porosity resulting from hydrothermal mineral alteration and precipitation typically occurs with increasing depth (McDowell and Elders, 1979, 1980b). Measurements of porosity from thin sections, however, a re tedious, time consuming, and occasionally inaccurate. Also, only the porosities of sandstones can be routinely measured. Therefore, a combination of log data and petrophysical measurements on cores have been used to resolve the effects of hydrothermal alteration on porosity in the Salton Sea and Westmorland geothermal reservoirs. 


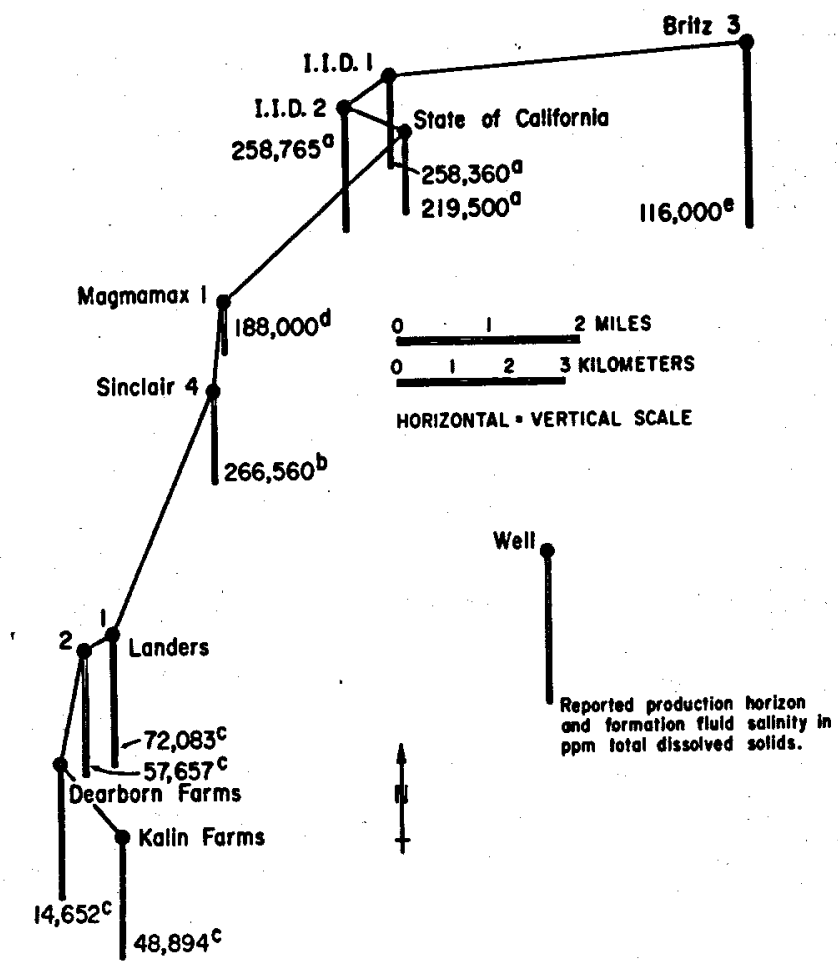

Figure 42. Fence diagram showing well depth, perforated interval, and formation fluid salinity for selected wells in the Salton Sea and Westmorland geothermal areas. Location of perforation horizon from Palmer (1975).

$a=$ Helgeson (1968)

$\mathrm{b}=$ California Department of Water Resources (1970)

$c=01$ son and Matlick (1977)

$d=$ Needham et al. (1980)

$e=$ Republic Geothermal (1981, personal communication)

Porosity is normally estimated from density using the equation

$$
\phi=\left(\rho_{g r}-\rho_{B}\right) /\left(\rho_{g r}-\rho_{f}\right),
$$

where $\rho g r$ is the grain density (normally $2.65 \mathrm{gm} / \mathrm{cm}^{3}$ for quartz), $\rho B$ is the bulk density estimated from the gamma-gamma density $10 \mathrm{~g}$, and of is the fluid density. Scrutiny of the above equation in its application to geothermal fields reveals two possible sources of error when calculating porosity: (1) assuming that the fluid density is unity; and (2) assuming that grain density has not changed with authigenic mineral transformations occurring with increasing alteration. In the former case, the fluid density is usually not equal to $1 \mathrm{gm} / \mathrm{cm}^{3}$ for highly saline fluids (e.g., for 20 wt. $\% \mathrm{NaCl}$ solution at $20^{\circ} \mathrm{C}, \rho_{B}=1.19 \mathrm{gm} / \mathrm{cm}^{3}[$ Wolf et al.., 1974]). Furthermore, a decrease in fluid denşity occurs with rising temperature; consequently, assuming a of of $1.0 \mathrm{gm} / \mathrm{cm}^{3}$ may lead to erroneous estimates of porosity. For example, Table 3 shows the varying densities of pure water and 5.7 molal (20 wt. \%) NaCl solution at increasing temperatures (Helgeson and Kirkham, 1974; Haas, 1970; Wolf et al.., 1974) together with the associated porosity computation. Clearly, $\phi$ will change depending upon the of used. The percent error can then be calculated as

$$
\text { Percent Error }=\left(\phi-\phi_{t}\right) 100=\left[\frac{2.65-\rho_{B}}{2.65-1}-\frac{2.65-\rho_{B}}{2.65-\rho_{f T}}\right] 100
$$


TABLE 3

Fluid Density Variation with Temperature of Pure Water and $20 \mathrm{wt}$. \% $\mathrm{NaCl}$ Solution and The ir Associated Porosity Calculation

\begin{tabular}{|c|c|c|c|c|c|}
\hline Temperature & $\begin{array}{l}\text { Pressure (bars) } \\
\text { (Hel geson and } \\
\text { Kirkham, 1974) }\end{array}$ & $\begin{array}{c}\rho f \text { Pure water } \\
\text { (Helgeson and Kirkham) }\end{array}$ & Calculated $\phi^{*}$ & $\begin{array}{l}\rho_{f} 5.7 \text { molal (20 wt. \%) } \\
\text { NaCl Solution } \\
\text { (Haas, 1971, Fig. 1; } \\
\text { Wolf and others, ig74) }\end{array}$ & Calculated $\phi^{\star}$ \\
\hline $0^{\circ} \mathrm{C}$ & .006 & 1.00 & .152 & -- & -- \\
\hline $20^{\circ} \mathrm{C}$ & .023 & .998 & .151 & 1.19 & . 171 \\
\hline $200^{\circ} \mathrm{C}$ & 15.54 & .865 & .140 & 1.06 & .157 \\
\hline $300^{\circ} \mathrm{C}$ & 85.81 & .713 & .129 & 0.82 & .137 \\
\hline
\end{tabular}

$*_{\phi}=\left(\rho_{g r}-\rho_{B}\right) /\left(\rho_{g r}-\rho_{f}\right)$ where $\rho_{g r}=2.65 \mathrm{gm} / \mathrm{cm}^{3}$ and $\rho_{B}=2.40 \mathrm{gm} / \mathrm{cm}^{3}$. 
where $\phi_{t}$ is the true porosity, $\rho_{\mathrm{fT}}$ is the true fluid density, and $\rho_{\mathrm{gr}}$ is assumed to be $2.65 \mathrm{gm} / \mathrm{cm}^{3}$. It is obvious from the above equation that if of is not chosen carefully, errors in the calculation of sandstone porosity may be incurred.

In the SSGS, however, Helgeson (1968) states that the brine must have a fluid density of $1.0 \mathrm{gm} / \mathrm{cm}^{3}$ to at least $7000 \mathrm{ft}(2134 \mathrm{~m})$ in order to satisfy the observed hydrostatic gradient (0.0295 atmospheres/ft) in this field. Hence, the error in the calculation of porosity caused by decreasing fluid density with increasing temperature may be negated by the increase of salinity counteracting the effect of increasing temperatures.

In the other case, an increase in grain density resulting from authigenic mineral transformations occurs with increasing alteration. This increase in grain density may introduce an additional error in calculating porosity. For example, in the SSGS the average density of the sandstones from the chlorite zone is found to be $2.68 \mathrm{gm} / \mathrm{cm}^{3}$; for the feldspar zone of the sandstones, the average density is $2.81 \mathrm{gm} / \mathrm{cm}^{3}$. These values are calculated using average mineral concentrations by weight, converting weight percent to volume percent (McDowe11, unpublished, Appendix 3), estimating mineral densities, determining volumetric contributions of each mineral per unit area of the rock, and the summation of all contributions (Table 4).

In order to compute the effect of grain density variation on porosity, the following equation can be employed, assuming that there is no loss or gain of material in transforming a rock, for example, from the chlorite to the feldspar zone:

$$
\Delta \phi_{f l-c h}=\phi_{f l}-\phi_{\text {ch }}=\frac{\rho_{\text {grfl }}-\rho_{\text {grch }}}{\rho_{\text {grfl }}}
$$

(from Seamount, 1981)

where $\phi_{f l}=$ porosity estimated using the $\rho_{g r}$ of the feldspar zone

$\phi_{c h}=$ porosity estimated using the $\rho_{g r}$ of the chlorite zone

$\rho_{\text {grfl }}=$ grain density of the feldspar zone

assuming:

$\rho_{\text {grch }}=$ grain density of the chlorite zone

therefore:

$$
\text { ogrfl }=2.81 \mathrm{gm} / \mathrm{cm}^{3}
$$

$$
\Delta \phi_{f l-c h}=\phi_{f l}-\phi_{c h}=0.046 \text {. }
$$

A minute change in porosity probably occurs with the variation in grain density from the chlorite zone to the feldspar zone; however, this change appears to have little effect on porosity. Furthermore, assuming that $\rho_{\mathrm{gr}}$ is equal to $2.65 \mathrm{gm} / \mathrm{cm}^{3}$ will lead to slightly low estimates of porosity. Porosity of core samples measured in the lab by petrophysical techniques was compared with. $\rho$ B (Table 5) using the equations:

$$
\begin{aligned}
& \rho_{B L}=\phi \rho_{f}+(1-\phi) \rho_{g r} \\
& \phi_{l o g}=\left(\rho_{g r}-\rho_{B}\right) /\left(\rho_{g r}-\rho_{f}\right)
\end{aligned}
$$


TABLE 4

Calculation of $\mathrm{Pgr}_{\mathrm{gr}}$ for Average Sandstones of the Chlorite and Feldspar Zone

\begin{tabular}{|c|c|c|c|c|c|c|c|c|c|c|}
\hline & \multicolumn{5}{|c|}{ Chlorite Zone } & \multicolumn{5}{|c|}{ Feldspar Zone } \\
\hline Mineral & Wt \% & $\left(\mathrm{gm}^{\mathrm{p}} \mathrm{cm}^{\star \star}\right)$ & Wt $\% / \mathrm{pgr}$ & Vol $\%^{t}$ & $\begin{array}{l}\text { Den contr./Unit } \\
\text { vol }\left(\mathrm{gm} / \mathrm{cm}^{3}\right)^{\alpha}\end{array}$ & Wt \% & $\left(\stackrel{p m / \mathrm{cm}^{3}}{\mathrm{gr}}\right)$ & Wt $\% / \rho g r$ & Vol $\%$ & $\begin{array}{l}\text { Den contr./Unit } \\
\text { vol }\left(\mathrm{gm} / \mathrm{cm}^{3}\right)\end{array}$ \\
\hline Quartz & .413 & 2.65 & .156 & .399 & 1.06 & 46.5 & 2.65 & .175 & .385 & 1.02 \\
\hline Plagioclase & .085 & 2.65 & .032 & .077 & .20 & 16.6 & 2.65 & .063 & .139 & .37 \\
\hline Alkali feldspar & .069 & 2.57 & .027 & .058 & .15 & 9.5 & 2.57 & .037 & .081 & .21 \\
\hline Mica & .051 & 2.80 & .020 & .051 & .14 & 6.6 & 2.80 & .026 & .053 & .15 \\
\hline Illite & .055 & 2.80 & .019 & .049 &. .14 & 7.6 & 2.80 & .027 & .059 & .17 \\
\hline Vermiculite & .095 & 2.76 & .034 & .087 & .24 & 3.0 & 2.76 & .011 & .024 & .07 \\
\hline Chlorite & 096 & 2.80 & .034 & .087 & .24 & 8.1 & 2.80 & .029 & .064 & .18 \\
\hline Calcite & .103 & 2.72 & .038 & .097 & .26 & 4.1 & 2.72 & .015 & .033 & .09 \\
\hline Pyrite & .011 & 5.02 & .002 & .005 & .03 & 1.8 & 5.02 & .004 & .009 & .05 \\
\hline Amphibole & .000 & 3.28 & .00 & .00 & .00 & 2.3 & 3.28 & .007 & .015 & .05 \\
\hline Epidote & .047 & 3.60 & .013 & .033 & .12 & 15.5 & 3.60 & .043 & .095 & .34 \\
\hline Anhydrite & .014 & 2.96 & .005 & .013 & .04 & 5.0 & 2.96 & .017 & .037 & .11 \\
\hline Zeolite $e^{\beta}$ & .025 & 2.26 & .011 & .028 & .06 & .00 & 2.26 & 0 & 0 & 0 \\
\hline TOTAL & & & .391 & & $\begin{array}{c}2.68 \\
\mathrm{gm} / \mathrm{cm}^{3}\end{array}$ & & 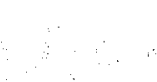 & .454 & & $\begin{array}{c}2.81 \\
\mathrm{gm} / \mathrm{cm}^{3}\end{array}$ \\
\hline
\end{tabular}

* from McDowell, unpublished (see Appendix 3).

** from Birch and others (1942).

$t$ Vol $\%=\left(w t \% / \rho_{\text {gr }}\right) /\left(\Sigma\right.$ wt $\left.\% / \rho_{g r}\right)$.

a. Density contribation per unil volume $=$ Vol $\% \times \rho \mathrm{gr}$
B. 
TABLE 5

Porosity and Density Measurements from Petrophysical Analysis of Cores and Density Logs

\begin{tabular}{|c|c|c|c|c|c|c|}
\hline & & \multicolumn{3}{|c|}{ Lab Measurements } & \multicolumn{2}{|c|}{ Log Measurements } \\
\hline Well & $\begin{array}{r}\text { Depth } \\
(\mathrm{ft})\end{array}$ & $\begin{array}{l}\text { Measured } \phi \\
\text { (at UCR) }\end{array}$ & $\begin{array}{l}\rho_{\mathrm{BL}}{ }^{*} \text { from Lab } \\
\text { Data }\left(\mathrm{gm} / \mathrm{cm}^{3}\right)\end{array}$ & $\begin{array}{l}\text { Measured Grain } \\
\text { Density ( }\left(\rho_{\mathrm{gr}}\right) \\
\left(\mathrm{gm} / \mathrm{cm}^{3}\right)(\mathrm{at} \text { CR) }\end{array}$ & $\rho_{B}$ & $\begin{array}{c}\phi_{\log ^{\dagger}} \text { from }^{-} \\
\text {Data }\end{array}$ \\
\hline Dearborn Farms 1 & 5758 & 19.5 & 2.34 & 2.66 & 2.32 & 20.0 \\
\hline Dearborn Farms 1 & 7420 & 19.2 & 2.34 & 2.66 & 2.40 & 15.2 \\
\hline Landers $1^{\alpha}$ & 6352 & 4.2 & 2.56 & 2.63 & 2.61 & 2.4 \\
\hline Kalin Farms $1^{\beta}$ & 7114 & 14.2 & 2.40 & 2.63 & 2.50 & 9.1 \\
\hline Kal in Farms $1^{\beta}$ & 5374 & 4.7 & 2.45 & 2.52 & 2.10 & 33.3 \\
\hline
\end{tabular}

* $\rho_{B L}=\phi \rho_{f}+(1-\phi) \rho_{g r}$ where $\rho_{f}=1.00 \mathrm{gm} / \mathrm{cm}^{3}$.

$+\phi_{l o g}=\left(\rho_{g r}-\rho_{B}\right) /\left(\rho_{g r}-\rho_{f}\right) \quad \rho_{f}=1.00 \mathrm{gm} / \mathrm{cm}^{3}, \rho_{g r}=2.65 \mathrm{gm} / \mathrm{cm}^{3}$.

a Lithology red-brown shale.

$\beta$. Because of borehole rugosity greater than $20 \%$, these calculated and $\log \emptyset$ values are in poor agreement; hence, $\rho_{B}$ are not shown on Figure 18 . 
where $\phi$ is the lab-measured porosity and $\rho_{B L}$ is the bulk density calculated from $\phi$. In this calculation $\rho_{f}$ is assumed to be unity, and its decrease with increasing temperature is not accounted for. Thus, $\phi_{10 g}$ may be higher than the actual case.

Only core samples from the Westmorland geothermal area were analyzed since log porosity data and/or core samples are lacking for the wells examined in the SSGS. Close agreement between the lab-measured porosities and the log values is evident even though $\rho_{f}$ is assumed to equal $1 \mathrm{gm} / \mathrm{cm}^{3}$. Consequently, the density logs of the WGS (Figures $17,19,20$ ) are representative of the actual densities encountered in these wells. In contrast, M. Mathews (personal communication, 1982) states that his attempts to check the accuracy of the density logs with core measurements in the East Mesa geothermal field were unsuccessful.

The densities of the shales and sandstones from the illite, chlorite, and feldspar are higher than those expected from normal compaction. Figure 43 shows the shale density curves from wells Magmamax 2, Magmamax 3, Landers 1, and Dearborn Farms 1 in relation to the unaltered shales of Cerro Prieto (Seamount, 1981), shallow young oceanic sediments (from sonic data, Nafe and Drake, 1957), Gulf Coast shales (gravity and petrophysical data, Nettleton, 1934; petrophysical and density log data, Dickinson, 1953). The shale log density curves of the Salton Sea and Westmorland geothermal areas show marked deviations from the compaction curves of recent, unaltered sediments. This indicates that induration greater than that expected from compaction alone has occurred.

An attempt was made to obtain porosity from electric logs by utilizing Archie's equation (1942):

$$
F=a \phi^{-m}=R_{t} / R w \quad \text { (symbols previously defined). }
$$
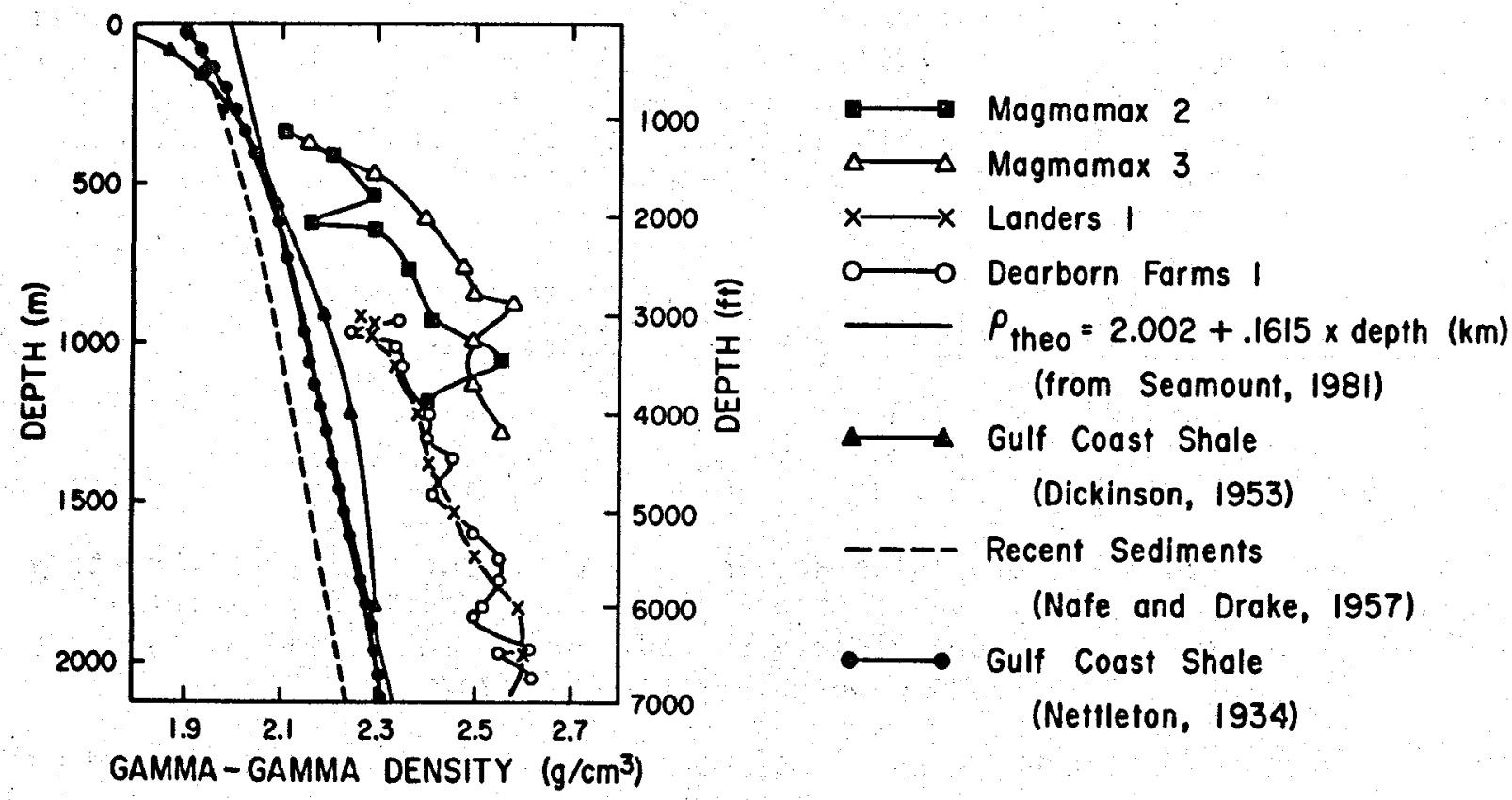

Figure 43. A comparison of densities of unaltered and altered shale vs. depth in wells Magmamax 2, Magmamax 3, Landers 1, and Dearborn Farms 1. 
By taking the logarithm of the above equation and rearranging the terms, one obtains the following equation:

$$
\log R_{t}=-m \log \phi+\log \left(a R_{w}\right)
$$

Therefore, if both $R_{t}$ and $\phi$ are known, linear regression analysis will give the quantity, $m$, which is needed for the porosity calculation. The porosity data were acquired from gamma-gamma density logs of wells Magmamax 2 (Figure 11) and Magmamax 3 (Figure 12), the only wells that have porosity data within the feldspar zone in the Salton Sea field. Note, however, that in order to use this equation, $R_{W}$ has to be fairly constant in the zone of interest. The relatively constant Rsd within the feldspar zone of these wells satisfies the latter requirements with omission of some anomalous data. The following $\mathrm{m}$ values were obtained.

\begin{tabular}{|c|c|c|}
\hline Well & $\mathrm{m}$ & Correlation Coefficient \\
\hline Magmamax 2 & 1.10 & 0.36 \\
\hline Magmamax 3 & 1.92 & 0.35 \\
\hline gmamax 2 and 3 & 0.84 & 0.29 \\
\hline
\end{tabular}

These low correlation coefficients signify a poor linear regression fit of data points (Figure 44). Nevertheless, these $m$ values were used in order to compute porosities for well I.I.D. 2. This well was chosen for this study to acquire valuable log porosity data for the anomalous zone between approximately $2900-4000 \mathrm{ft}\left(915-1220 \mathrm{~m}\right.$ ) (Figure 12). In using Equation 7, $R_{W}$ was obtained from graphs given by Ucok et al. (1980)* for $20 \mathrm{wt}$. \% NaCl solution** at a formation temperature of $305^{\circ} \mathrm{C}$ acquired from temperature logs (Figure 6 , Helgeson, 1968). Furthermore, the constant, $a$, is assumed to be unity. The calculated porosities are shown below and are compared to core data at equivalent depths and lithology.

\begin{tabular}{|c|c|c|c|c|}
\hline Depth $(\mathrm{ft})$ & m & Calculated $\phi$ & $\begin{array}{l}\text { Laboratory Measurement } \\
\text { (MCDowel1, unpublished) }\end{array}$ & Lithology \\
\hline 3504 & 1.92 & $13 \%$ & $32.9 \%$ & siltstone \\
\hline 3504 & 1.10 & $2.85 \%$ & $32.9 \%$ & siltstone \\
\hline
\end{tabular}

Although the calculated porosities are in poor agreement with the laboratorymeasured values, it is believed that this method might still be useful if applied to wells that are more closely spaced so that inter-well differences such as lithology, salinity, and porosity are minimized.

\#Ucok et al.'s (1980) graph was used since maximum temperatures published on Schl umberger's and Dresser Atlas's nomographs for $R_{W}$ computation are only $230^{\circ} \mathrm{C}$. ** One limitation of using the graph of Ucok et al. (1980) is that the maximumcalculated $R_{W}$ is for $20 \mathrm{wt} . \% \mathrm{NaCl}$ solutions when the TDS for I.I.D. 2 is actually near 250,000 TDS (25 wt. \% TDS). 


\section{A COMPARISON BETWEEN THE SALTON SEA AND CERRO PRIETO GEOTHERMAL FIELDS}

The method of correlating mineral zones defined by shale x-ray diffraction data with $\log$ responses has been applied successfully by Seamount (1981) to wells in the Cerro Prieto geothermal field, located approximately $85 \mathrm{~km}$ to the south-southeast of the SSGS (Figure 1). Even though both fields are situated within the deltaic sediments of the Colorado River and have temperatures in excess of $300^{\circ} \mathrm{C}$ at drilled depths, intrinsic and extrinsic characteristics of these fields make each distinct fram one another. In this section a discussion of these characteristics, their effect on log responses, and other relevant data is given.

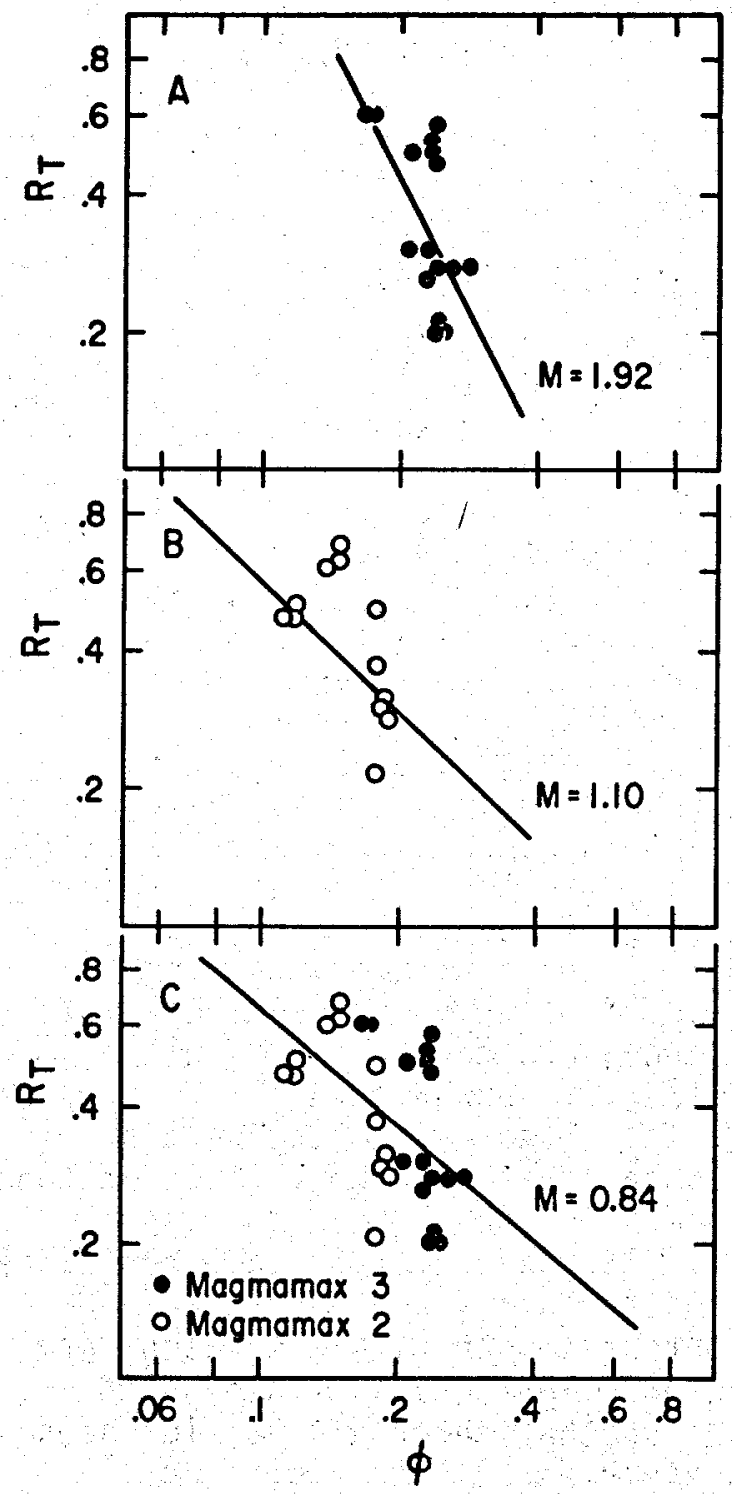

Figure 44. Crossplot of resistivityporosity $\left(R_{t}-\phi\right)$ for the feldspar zone in two wells, showing linear regression of the data. $A=$ Magmamax 3; $B=$ Magma$\max 2 ; C=$ combined data of $A$ and $B$.
The intrinsic features which differentiate these fields are salinity and to a lesser extent, stratigraphy. The maximum reported salinities from the SSGS are greater than 250,000 TDS which is an order of magnitude higher than that at Cerro Prieto. Figure 45 compares the resistivity vs. temperature curves for well Elmore 1 in the SSGS and well T366 in Cerro Prieto. This crossplot is used to show the effects of salinity on overall log response, assuming that equivalent mineral assemblages have virtually identical effects on resistivity between the two wells. Clearly, the resistivity-temperature curve for well Elmore 1 is lower than for well T366. The higher salinity in the SSGS presumably causes the overall lowering of resistivity responses in all mineralogic zones as compared to Cerro Prieto.

Stratigraphically, the lacustrine sequence present in the SSGS is absent at Cerro Prieto. As stated earlier, the existence of this clay-silt-evaporite sequence causes problems in demarcating mineral zones in the upper portions of the wells (see pages 32-33). Extrinsically, the number and spacing of geothermal wells with complementary wireline log data differ widely between these two fields. At Cerro Prieto more than 110 wells have been drilled by the La Comision Federal de Electricidad de Mexico (CFE). Several different wireline logs are available for each of these wells and all data are in the public domain. In comparison, 
fewer wells have been drilled in the SSGS. Much of the old and new data gathered on this field are held proprietary by the operating companies. Also, since many of the wells in the SSGS were drilled in the early 1960's, the induction electrical log was commonly the only wireline log run. The study of wireline logs in the SSGS has not shown any distinguishable fluid flow patterns as in Cerro Prieto, where wireline $\log$ responses reaffirmed the reservoir dynamics based previously on petrologic data (Seamount and Elders, 1981).

\section{SUMMARY AND CONCLUSION}

This study has confirmed that wireline logs run in sedimentary geothermal fields can be used to determine various reservoir properties. In addition, from analysis of $\log$ data, qualitative estimates of temperature and alteration mineralogy can also be made.

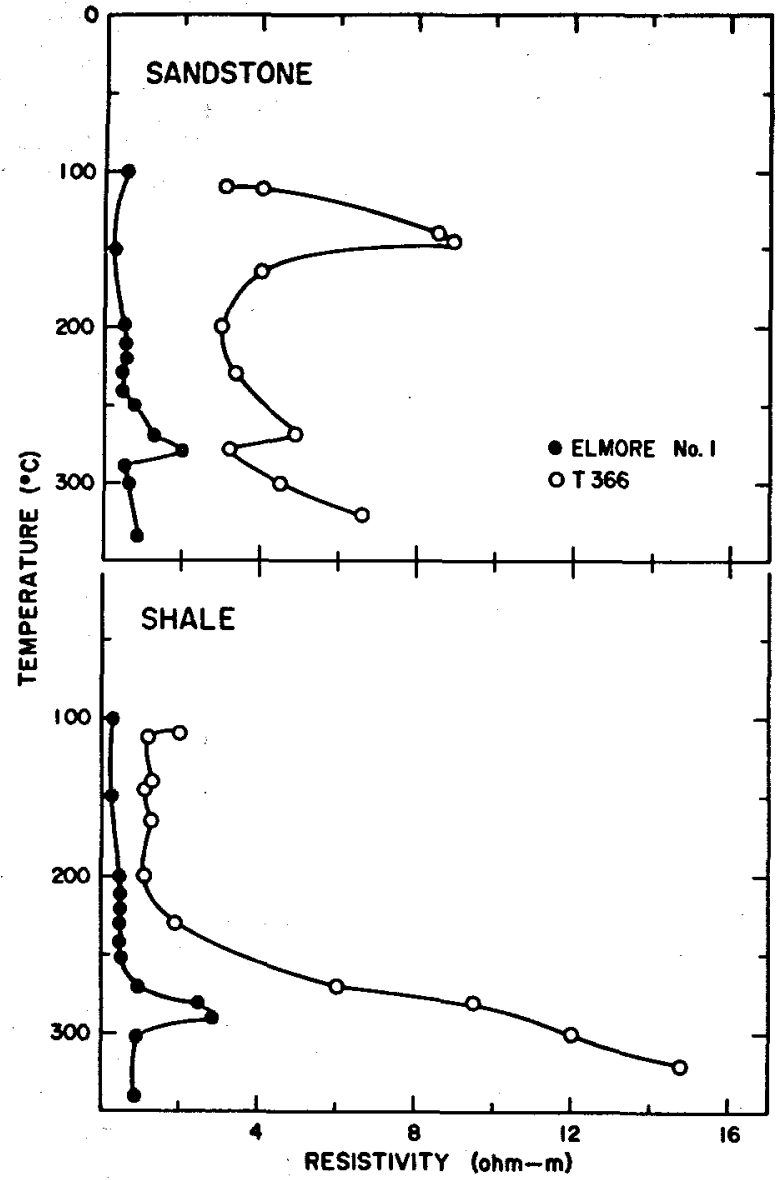

Figure 45. A resistivity-temperature crossplot showing wells Elmore 1 (SSGS) and T366 in the Cerro Prieto geothermal field. Temperature data for well T366 are from Barker (1979). Temperature data for well Elmore 1 are from Helgeson (1968).
For the Salton Sea geothermal system, definite correspondence between $\log$ responses and mineralogy of shales is observed. Four mineralogic zones in which one is unaltered and three are hydrothermal can be identified from log data of shale. The zones, correlated with temperature, are:

Montmorillonite zone (unaltered) $\angle 100^{\circ} \mathrm{C}$ to $190^{\circ} \mathrm{C}$.

Illite zone $-100^{\circ}-190^{\circ} \mathrm{C}$ to $230^{\circ}$ $250^{\circ} \mathrm{C}$.

Chlorite zone $-230^{\circ}-250^{\circ} \mathrm{C}$ to $290^{\circ}$ $300^{\circ} \mathrm{C}$.

Feldspar zone $->290^{\circ}-300^{\circ} \mathrm{C}$. Both sandstone and shale log data should be compared in order to identify the $\log$ responses of these mineral zones.

The characteristic log responses from which these mineralogic zones are determined result primarily from changes in clay mineralogy of the shales. These mineralogic changes are the conversion of montmorillonite and mixed layer clays to illite and chlorite and then finally to feldspars and quartz. In sandstones, both clay mineralogy and formation water salinity affect $\log$ responses; hence, analysis of sandstone data is more difficult.

The montmorillonite zone, the shallowest of the mineral zones studied and the most poorly controlled mineralogically because of sampling problems, is characterized by fairly constant resistivity 
responses of shale and sandstone (if present). The gamma-gamma density is typically less than $2.2 \mathrm{gm} / \mathrm{cm}^{3}$. The exact location of the base of the montmorillonite zone, however, is difficult to locate in several wells of the SSGS because of the masking effects of the clay-silt-evaporite lacustrine sequence. The top of the illite zone is indicated by a rise in shale resistivity probably caused by the loss of montmorillonite and a decrease in the cation exchange capacity of the clays. From the limited gamma-gamma density data avallable, it also appears that a rapid rise in shale density occurs at the top of the illite zone. This rapid rise probably indicates induration of the sediments. The chlorite zone is distinguished by an increase in both sandstone and shale deep induction resistivity $(R)$. The maximum $\rho_{B}$ values in this zone are $2.40 \mathrm{gm} / \mathrm{cm}^{3}$ for sandstones and $2.60 \mathrm{gm} / \mathrm{cm}^{3}$ for shales. The $10 \mathrm{~g}$ response of the feldspar zone is a rise in shale resistivity accompanied by a decrease in sand resistivity.

For the Westmorland geothermal field, only limited success was obtained in identifying mineral zones from $\log$ responses. The analysis of well $\log$ and petrologic data for wells Landers 1 and Kal in Farms 1 in this field suggests that Landers 1 is heating up while Kalin Farms is cooling.

other methods were also shown to be effective in delineating mineral zones. The Rsd/Rsh ratio method calculated in 50- $\mathrm{ft}(15-\mathrm{m})$ intervals shows a decrease from approximately 0.8 to 2.0 in the 111 ite zone to less than 0.4 in the feldspar zone. Another useful method is the crossplotting of gamma-gamma density $\left(\rho_{B}\right)$ data against resistivity $(R)$. This crossplot distinguishes mineral zones in shales readily. Lastly, crossplotting the neutron porosity divided by density against resistivity proved more effective in separating the zones than the other crossplot. Both crossplots were, however, unsuccessful in delineating zones from sandstone data.

Testing of certain empirical methods used in this study to identify mineral zones was of limited success. It was concluded that for wells on the fringes of the SSGS, supplementary porosity data are needed to locate zone boundaries more accurately.

Certain reservoir characteristics must be taken into account in order to make accurate interpretations of log data. First, knowledge of the salinity profile in a well is advantageous since changes in salinity can affect log data of porous rocks. Second, highly resistive zones caused by minerals such as anhydrite must be recognized. This can be accomplished by detailed inspection of lithologic logs in many cases. Third, thick shale horizons in a well which may alter log responses, as demonstrated in well Elmore 1, must be considered.

Petrophysical, $\rho_{B}$, and petrographic data indicate that induration of the sandstone and shale nas occurred within all altered zones. The gamma-gamma density $\log$ has been shown to be fairly accurate in recording true formation density values in a hydrothermal environment. Porosity derivation from electric logs was unsuccessful; however, it is believed that this method may be valuable if the wells being studied were more closely spaced so that inter-well differences such as salinity and lithology could be allowed for.

The log-derived salinity values are in poor agreement with the actual observed formation water salinity. Nevertheless, the trend of the log-derived sal inity data probably reflects the trend of the actual salinity profile in the well.

Until high-temperature resistant tools and calibration data for the unusual lithologies encountered in geothermal reservoirs are available to provide better quantification and interpretation, the empirical methods used in this study can be employed to assess various reservoir parameters in sedimentary-type geothermal systems. 


\section{ACKNOWLEDGMENTS}

We are particularly appreciative of Mark Mathews' interest in our work, his advice on various aspects of we 11 log analys is, and his insightful review of this manuscript. Thanks are also due to Corky Isselhardt and Chuck Ritz of Republic Geothermal, Inc. for releasing samples, wireline logs, and other information that was usefur in this study.

We want to thank L. H. Cohen, A. E. Williams, S. D. McDowe11, S. Biehler, T. - C. Lee, P. Collier, and D. Seamount, all of whom assisted in material ways with this study. L. K. Jankov drafted the figures, and the manuscript was prepared by L. Love11.

\section{REFERENCES}

Adams, J. A. S., "Uranium and Thorium Content of Volcanic Rocks," in Nuclear Geology, H. Fau1, Ed. (John Wiley \& Sons, Inc., New York, 1954), pp. 89-98.

Albores, A. L., C. A. Z. Reyes, J. N. Brune, J. G. Gonzalez, L. M. Garcilazo, and F. V. Suarez, "Seismicity Studies in the Region of the Cerro Prieto Geothermal Field, "Proc. First Symp. on the Cerro Prieto Geothermal Field, Baja California, Mexico, September 20-22, 1978 (Lawrence Berkeley Laboratory report 7098, 1979 ), pp. 227-238.

Applegate, J. K. and T. A. Moens, "Geophysical Logging Case History of the Raft River Geothermal System, Idaho," Los Alamos Scientific Laboratory report LA-8252-MS (Apri 1 1980).

Archie, G. E., "The Electrical Resistivity Log as an Aid in Determining Some Reservoir Characteristics," SPE of AIME, Petrol. Trans. Reprint Series, 1958, no. 1-4 (1942).

Arps, J. J., "The Effect of Temperature on the Density and Electrical Resistivity of Sodium Chloride Solutions," Trans., AIME, v. 198, pp. 327-330 (1953).

Athy, L. F., "Density, Porosity and Compaction of Sedimentary Rock," Bul1. Amer. Assoc. Petrol. Geol., v. 14, pp. 1-24 (1930).

Barker, C. E., "Vitrinite Reflectance Geothermometry in the Cerro Prieto Geothermal System, Baja California, Mexico," M.S. Thesis, University of California, Riverside/Institute of Geophysics and Planetary Physics report 79/10 (1979).

Barsukov, 0. A., N. M. Blinova, S. F. Vybornykh, Yu A. Gulin, V. N. Darkhnov, V. V. Larionov, and A. I. Kohlin, Radioactive Investigations of 0il and Gas Wells (Pergamon Press, MacMillan Co., New York, 1965).

Bateman, R. M. and C. E. Konen, "The Log Analyst and the Programmable Pocket Calculator," The Log Analyst of the SPWLA, V. XVIII, no. 5, pp. 3-11 (1977a).

Bateman, R. M: and C. E. Konen, "The Log Analyst and the Programmable Pocket Calculator -- Part IV," Dual Induction Laterolog 8, The Log Analyst of the SPWLA, v. XIX, no. 3, pp. 3-7 (1977b). 
Benoit, W. R., D. K. Sehti, W. Fertl, and M. Mathews, "Geothermal Well Log Analys is at Desert Peak, Nevada," Trans. 21st Annual Logging Symp. of the SPWLA, paper AA $(1981)$.

Biehler, S, "Gravity Studies in the Imperial Valley," in "Cooperative Geologica 1-Geophysical-Geochemical Investigations of Geothermal Resources in the Imperial Valley Area of California," Final Report (FY1971), Contr. No. 14-06-300-2194, U.S. Bureau of Reclamation, Pp. 29-42 (1971).

Biehler, S., "A Geophysical Study of the Salton Trough of Southerna California," Ph.D. Thesis, California Institute of Technology (1964).

Birch, F., J. F. Shairer, and L. Spicer, "Handbook of Physical Constants," Geol. Soc. Am. Special Paper 36 (1942).

Bird, D. K. and D. L. Norton, "Theoretical Prediction of Phase Relations Among Aqueous Solutions and Minerals, Salton Sea Geothermal System," Geochem. et Cosmochim. Acta, v. 45, pp. 1469-1493 (1981).

Browne, P. R. L., "Hydrothermal Alteration in Active Geothermal Fields," Ann. Rev. Earth Planet. Sci., v. 6, pp. 229-250 (1978).

Burke, J. A., A. W. Schmidt, and R. L. Campbe11, "The Litho-porosity Cross Plot," The Log Analyst of the SPWLA, v. X, no. 6, pp. 25-43 (1969).

California Department of Water Resources, "Geothermal Wastes and Water Resources of the Salton Sea, Bull. 143-7 (1970).

California Division of 0il and Gas, Map of the Salton Sea (1981).

Chan, M. A. and J. D. Tewhey, "Subsurface Structure of the Southern Portion of the Salton Sea Geothermal Field," Lawrence Livermore Laboratory report UCRL-52354 (1977).

Chase, D. S., R. C. Clover, R. B. Grannel, R. M. Leggewie, J. Eppink, D. W. Tarman, and N. E. Goldstein, "Precision Gravity Studies at Cerro Prieto," Proc. First Symp. on the Cerro Prieto Geothermal Field, Baja California, Mexico, September 20-22, 1978 (Lawrence Berkeley Laboratory report 7098, 1979), pp. 249-264.

Cox, B., "Reconnaissance Petrology of the River Ranch \#1 Geotherma 1 We11, Salton Sea Geothermal Field, California," Unpublished Manuscript, University of California, Riverside (1977).

Davis, D. G. and S. K. Sanya 1, "Case History Report on East Mesa and Cerro Prieto Geothermal Fields," Los Alamos Scientific Laboratory report LA-7889-MS (June 1979).

Dibblee, Jr.,.T. W., "Geology of the Imperial Valley Region, California," in "Geology of Southern California," R. H. Jahns, Ed., Calif. Div. Mines Bull., v. 170, pp. 21-28 (1954). 
Dickinson, G., "Reservoir Pressures in Gulf Coast Louisiana," Bull. Amer. Assoc. Petrol. Geol., v. 37, no. 2, pp. 410-432 (1953).

Dresser Atlas, Log Review 1 (Dresser Industry, Inc., Houston, Texas, 1974).

Elders, W. A., "The Geological Background of the Geothermal Fields of the Salton Trough," in "Geology and Geothermics of the Salton Trough," W. A. Elders, Ed., University of California, Riverside Campus Museum Contribution no. 5, pp. 1-19 (1979).

Elders, W. A. and S. Biehler, "Gulf of California Rift System and its Implication for the Tectonics of Western North America," Geology, v. 3 , no. 2, p. 85 (1975).

Elders, W. A., J. R. Hoagland, S. D. McDowe11, and J. M. Cobo, "Hydrothermal Mineral Zones in the Geothermal Reservoir of Cerro Prieto," Geothermics, v. $\underline{8}$, pp. 201-209 (1979).

Elders, W. A., E. 01son, J. R. Hoagland, C. Barker, P. Johnson, and P. Collier, "A Comprehensive Study of Samples from Geothermal Reservoirs: Petrology and Light Stable Isotope Geochemistry of Wells M48, M84, M90, M91 and Prian No. 1," Final Report to the Department of Energy/Lawrence Berkeley Laboratory no. 7100410 (1977).

Elders, W. A., R. Rex, T. Meidav, P. T. Robinson, and S. Biehler, "Crustal Spreading in Southern California," Science, v. 178, pp. 15-24 (1972).

Englehardt, W. V. and K. H. Gaida, "Concentration Changes of Pore Solutions During the Compaction of Clay Sediments," Jour. Sed. Pet., v. 33, pp. 919-930 (1963).

Ershaghi, I., S. Ghaemaian, and D. Abdassah, "Lithology and Hydrothermal Alteration Determination from Well Logs for the Cerro Prieto Wells, Mexico," Los Alamos National Laboratory report LA-9075-MS (October 1981).

Ershaghi, I., S. Ghaemian, and M. Mathews, "Detection of Hydrothermal Alteration in Sedimentary Type Geothermal Systems Using Well Logs," Trans., 55th Ann. Tech. Conf. and Exhibition of SPE of AIME (Dallas, Texas, September 21-24, 1980).

Ershaghi, I., L. B. Phillips, E. L. Dougherty, L. L. Handy, and M. Mathews, "Application of 0ilfield Well Log Interpretation to the Cerro Prieto Geothermal Field," Trans., 20th Annual Logging Symp. of the SPWLA, pp. PP1-PP11 (1979).

Ershaghi, I., E. L. Dougherty, H. Ucok, and F. Ghassemi, "Problems in Estimation of Salinity Profiles in Liquid Dominated Geothermal Systems," Irans., Geothermal Resources Council, v. 2, sec. 2, pp. 181-184 (1978).

Freckman, J. T., "Fluid Inclusion and Oxygen Isotope Geothermometry of Rock Samples from Sinclair \#4 and Elmore \#1 Boreholes, Salton Sea Geothermal Fie1d, Imperial Valley, California, U.S.A.," M.S. Thesis, University of California, Riverside/Institute of Geophysics and Planetary Physics report $\underline{78 / 5}$ (1978). 
Friedman, I. and J. R. O'Neil, "Compliation of Stable Isotope Fractionation Factors of Geochemical Interest, Chapter KK," in Data of Geochemistry, US Geological Survey Professional Paper 440-KK (1977).

Geotherma 1 Resources Council, Geothermal Map of the Imperial County, California, Scale 1:126,720 (1981).

Gilpin, B. and T.-C. Lee, "A Microearthquake Study in the Salton Sea Geothermal Area, California," Bul1. Seis. Soc. Am., v. 68, pp. 441-450 (1978).

Gobran, B. D., S. L. Brown, and S. K. Sanyal, "A Hand Held Calcu-program for Estimating Water Salinity from Well Logs," Log Analyst of the SPWLA, V. XXII, no. 2 , pp. 25-47 (1981).

Grim, R. E., Clay Mineralogy (McGraw-Hi.11, New York, 1953).

Haas, J. L., "The Effect of Salinity on the Maximum Thermal Gradient of a Hydrothermal System at Hydrostatic Pressure," Econ. Geol., v. 66, pp. 940-946 (1971).

Haas, J. L., "An Equation for the Density of Vapor Satured $\mathrm{NaCl}-\mathrm{H}_{2} \mathrm{O}$ Solutions from $75^{\circ}$ to $325^{\circ} \mathrm{C}$. Amer. Jour. Sci., v. 269, pp. 489-493 (1970).

Helgeson, H. C., "Geologic and Thermodynamic Characteristics of the Salton Sea Geothermal System," Amer. Jour. Sci., v. 266, pp. 129-166 (1968).

Helgeson, H. C. and D. H. Kirkham, "Theoretical Prediction of the Thermodynamic Behavior of Aqueous Electrolytes at High Pressures and Temperatures: I. Summary of the Thermodynamic/Electrostatic Properties of the Solvent," Amer. Jour. Sci., v. 274, pp. 1089-1198 (1974).

Hil1, D. P., P. Mowincki, and L. G. Peake, "Earthqaukes, Active Faults and Geothermal Areas in the Imperial Valley, California," Science, v. 188, pp. 1306-1308 (1975).

Hoagland, J. R., "Petrology and Geochemistry of Hydrothermal Alteration in Borehole Mesa 6-2, East Mesa Geothermal Area, Imperial Valley, California," M.S. Thesis, University of California, Riverside/Institute of Geophysics and Planetary Physics report $76 / 12$ (1976).

Humphreys, G., "Telluric Sounding and Mapping in the Vicinity of the Salton Sea Geothermal Area, Imperial Valley, California," M.S. Thesis, University of California, Riverside/Institute of Geophysics and Planetary Physics report 78/17 (1978).

Johnson, C. E. and D. M. Hadley, "Tectonic Implication of the Brawley Earthquake Swarm, Imperial Valley, California," Bull. Seis. Soc. Am., v. 66, pp. 1133-1144 (1976).

Johnson, W. L. and W. A. Linke, "Some Practical Applications to Improve Formation Evaluation of Sandstones in Mackenzie Delta," presented at 6 th Form. Eva 1. Symp. of Canadian Well Logging Soc. (Calgary, October 24-26, 1977). 
Kenda11, C., "Petrology and Stable Isotope Geochemistry of Three Wells in the Butte Area of the Salton Sea Geothermal Field, Imperial Field, California, U.S.A.," M.S. Thesis, University of California, Riverside/Institute of Geophysics and Planetary Physics report $76 / 17$ (1976).

Keys, W. S. and J. K. Sullivan, "Role of Borehole Geophysics in Defining the Physical Characteristics of the Raft River Geothermal Field, Idaho," Geophysics, v. 44, no. 6, pp. 1116-1141 (1980).

Lande, D., "A History of Drilling in the Imperial Valley," in "Geology and Geothermics of the Salton Trough," W. A. Elders, Ed., University of California, Riverside, Campus Museum Contribution no. 5, pp. 45-46 (1979).

Lawver, L. A. and D. L. Williams, "Heat Flow in the Central Gulf of California," Jour. Geophys. Res., v. 84 , no. 47, pp. 3465-3478 (1979).

Lee, T.-C. and L. H. Cohen, "Onshore and Offshore Measurements of Temperature Gradients in the Salton Sea Geothermal Area, California," Geophysics, v. 44, no.. 2, pp. 206-215 (1979).

Littleton, R. T. and E. E. Burnett, "Chemical Profile of the East Mesa Field, Imperial County, California," in 2nd Workshop on Sampling and Ana Tysis of Geothermal Effluents, sponsored by U.S. EPA (Las Vegas, Nevada, 1977).

Littleton, R. T. and E. E. Burnett, "The Salinity Profile of the East Mesa Field as Determined from Dual Induction Resistivity and SP Logs ; U.S. Bureau of Reclamation (October 1975).

Magara, K., "Compaction and Fluid Migration," in Practical Petroleum Gealogy (Elsevier Science, Amsterdam, 1978).

Mathews, M., "Calibration Models for Fractured Igneous Rock Environments," Trans., 21 st Annual Logging Symp. of the SPWLA, paper L (1980).

Maxant, J., "Variation of Density with Rock Types, Depth and Formation in the Western Canada Basin from Density Logs," Geophysics, v. 45, no. 6 , pp. $1061-1076$ (1980).

McDowe11, S. D., "Layer Silicate Minerals in Borehole Elmore \#1, Salton Sea Geothermal Field, California, U.S.A.," University of California, Riversidel Institute of Geophysics and Planetary Physics report 78/15 (1978).

McDowe11, S. D. and W. A. Elders, "Allogenic Layer Silicate Minerals in Borehole Elmore \#1, Salton Sea Geothermal Field, California," Am. Min., v. 68, pp. $1146-1159$ (1982).

McDowe11, S. D. and W. A. Elders, "Authigenic Layer Silicate Minerals in Borehole Elmore 1, Salton Sea Geothermal Field, California, U.S.A.," Contrib. Min. Petrol., v. 74, pp. 293-310 (1980a).

McDowell, S. D. and W. A. Elders, "Zonation of Active Greenschist Facies Metamorphism and Physical Properties of Sandstone in Salton Sea Geothermal Field," Geo1. Soc. Am., Abstr. W/Prog., p. 480 (1980b). 
McDowe11, S. D. and W. A. Elders, "Geothermal Metamorphism of Sandstone in the Salton Sea Geothermal System," in "Geology and Geothermics of the Salton Trough" W. A. Elders, Ed., University of California, Riverside Campus Museum Contribution no. 5 , pp. $70-76$ (1979).

McDowe11, S. D. and M. McCurry, "Mineralogical Variations in Borehole Elmore \#1, Salton Sea Geothermal Area: Preliminary Report," University of California, Riverside/Institute of Geophysics and Planetary Physics report 78/11 (1978).

McKibben, M. A., "Ore Minera Is in the Salton Sea Geothermal System, Imperial Valley, California, U.S.A.," M.S. Thesis, University of California, Riverside/. Institute of Geophysics and Planetary Physics report 79/17 (1979).

MCNitt, J. R., "Exploration and Development of Geothermal Power in California," Calif. Div. Mines and Geol., Special Report 75, pp. 31-34 (1963).

Meade, R. H., "Removal of Water and Rearrangement of Particles During the Compaction of Clayey Sediments - Review," US Geological Survey Professional Paper 497-B (1964).

Meidav, T. and.J. R. Howard, "An Update of Tectonics and Geotherma 1 Resource Magnitude of the Salton Sea Geothermal Resource," in "Geology and Geothermics of the Salton Trough," W. A. Elders, Ed., University of California, Riverside Campus Museum Contribution no. 5 , pp. 58-61 (1979).

Menard, H. W. and T. Atwater, "Changes in the Direction of Sea Floor Spreading," Nature, v. 219, pp. 463-467 (1970).

Merriam, R. and D. L. Bandy, "Source of Upper Cenozoic Sediments in the Colorado River Delta Region," Jour. Sed. Petrol., v. 35, pp. 911-916 (1965).

Miller, K. R. . "Petrology, Hydrothermal Mineralogy, Stable Isotope Geochemistry and Fluid Inclusion Geothermometry of Borehole Mesa 31-1, East Mesa Geothermal Field, Imperial Valley, California," M.S. Thes is, University of California, Riverside/Institute of Geophysics and Planetary Physics report $80 / 1$ (1980).

Muffler, L. J. P. and B. R. Doe, "Composition and Mean Age of Detritus of the Colorado River Delta in the Salton Trough, Southeastern California," Jour. Sed. Petrol., v. 38, pp. 384-399 (1965).

Muffier, L. J. P. and D. E. White, "Active Metamorphism of Upper Cenozoic Sediments in the Salton Sea Geothermal Field and the Salton Trough, Southeastern California," Geol. Soc. Am. Bul1., v. 80, pp. 157-182 (1969).

Nafe, J. E. and C. L. Drake, "Variations with Depth in Shallow and Marine Sediments of Porosity, Density, and Velocities of Compressional and Shear Waves," Geophysics, V. XXII, pp. 523-552, (1957).

Needham, Jr., P. B.,.W. D. Riley, G. R. Conner, and A. P. Murphy, "Chemical Analyses of Brines from Four Imperial Valley, California, Geothermal Wells," Soc. Petrol. Eng. Jour., v. 20, no. 2, pp. 105-112 (1980). 
Nettleton, L. L., "Fluid Mechanics of Salt Domes," Bull. Amer. Assoc. Petrol. Geol., v. 18, pp. 1174-1204 (1934).

01son, E. R., "Oxygen Isotope Studies of the Salton Sea Geothermal Field: New Insight," New Zealand DSIR Bull., v. 220, pp. 121-126 (1978).

01son, E. R. and J. S. Matlick, III, "A Flow-Through Model for the Westmorland Geothermal System, Imperial Valley, California," University of California, Riverside/Institute of Geophysics and Planetary Physics report 78/7 (1977).

O'Neil, J. R., R. N. Clayton, and T. K. Mayeda, "Oxygen Isotope Fractionation in Divalent Metal Carbonates," Jour. Chem. Phys., v. 51, no. 12, pp. 5545-5558 (1969).

0'Sullivan; T. P., "Geophysical Well Log Response to Fractured and Altered Zones in the Raft River, Idaho Geothermal Reservoir," M.S. Thesis, Wright State University (1979).

Palmer, T. D., "Characteristics of Geothermal Wells Located in the Salton Sea Geothermal Field, Imperial Valley, California," Lawrence Livermore Laboratory report UCRL-51976 (1975).

Randall, W., "An Analysis of the Subsurface Structure and Stratigraphy of the Salton Sea Geothermal Anomaly, Imperial Valley, California," Ph.D. Thesis, University of California, Riverside (1974).

Rex., R. W., "Heat Flow in the Imperial Valley of California," Irans., Am. Geophys. Union, v. 47, no. 1, p. 181 (1966).

Rigby, F. A. and G. P. Zebal, "Case History on Geothermal Well Log Interpretation, Surprise Valley, California," Los Alamos Scientific Laboratory report LA-8598-MS (June 1981).

Robinson, P. T., W. A. Elders, and L. J. P. Muffler, "Quarternary Volcanism in the Salton Sea Geothermal Field, Imperial Valley," Bull. Geol. Soc. Am., v. 87, pp. 347-360 (1976).

Rook, S. H. and G. C. Williams, "Imperial Carbon Dioxide Gas Field," Calif. Div. 0il and Gas Bull., v. 28, pp. 12-23 (1942).

Sanyal, S. K., L. E. Wells, and R. E. Bickham, "Geothermal We 11 Log Interpretation State of the Art," Los Alamos Scientific Laboratory report LA-8211-MS (January 1980).

Schlumberger, Log Interpretation Principles (Schlumberger Limited, New York, 1972).

Seamount, Jr., D. T., "Well Log Study of the Hydrothermally Altered Sediments of Cerro Prieto Geothermal Field, Baja California, Mexico," M.S. Thesis, University of California, Riverside/Institute of Geophysics and Planetary Physics report $81 / 5$ (1981). 
Seamount, Jr., D. T. and W. A. Elders, "Use of Wireline Logs at Cerro Prieto in Identification of the Distribution of Hydrothermally Altered Zones and Dike Locations and Their Correlation with Reservoir Temperature," Proc., Third Symp. on the Cerro Prieto Geothermal Field, v. 3 , pp. 123-133 (1981).

Sigurdson, D. R., T. Meidav, and R. V. Sharp, "Structure of Sediments Under the Salton Sea," Geol. Soc. Am., Abstracts, v. 3, pp. 192-193 (1971).

Tewhey, J. D., "Geological Characteristics of a Portion of the Salton Sea Geothermal Field," Lawrence Livermore Laboratory report UCRL-52267 (1977).

Ucok, H., I. Ershaghi, and G. R. 01hoeft, "Electrical Resistivity of Geothermal Brines," Jour. Pet. Tech., v. 32, no. 4, pp. 717-727 (1980).

van de Kamp, P. C., "Holocene Continental Sedimentation in the Salton Basin, California," Geol. Soc. Am. Bull., v. 84, pp. 827-848 (1973).

von Herzen, R. P., "Geothermal Heat Flow in the Gulfs of California and Aden," Science, v. 140, pp. 1207-1208 (1963).

Wolf, A. V., M. G. Brown, and P. G. Prentiss, "Concentrative Properties of Aqueous Solutions Conversion Tables," in Handbook of Chemistry and Physics, R. H. Weist, Ed. (CRC Press, Cleveland, Ohio, 1974), 55th Edition, pp. 224-225.

Wynn, M. R., "Next Door to Hell's Kitchen," Automobile Club of Southern California, Westways Magazine, v. 67, no. 2 (1975).

Younker, L. W., P. W. Kasameyer, and J. D. Tewhey, "Geological, Geophysical, and Thermal Characteristics of the Salton Sea Geothermal Field, California," Journ. Volcan. Geotherm. Res., v. 12, pp. 221-258 (1982). 


\section{APPENDICES}

Appendix 1 - Ceothermal well status (from Palmer, 1975).

Appendix 2 - Shale x-ray diffraction data .

Appendix 3 - Sandstone x-ray diffraction data .

Appendix 4 - Reconnaissance petrographic description of well Britz \#3.

Appendix 5 - Computation of $R_{t}$ and $R_{x o}$ from the Dual Induction-Laterolog (from Bateman and Konen, 1977b).

Appendix 6 - Summary of log data from Landers 1, Landers 2, and Dearborn Farms 1 used in salinity calculation together with temperature logs for Landers 2 and Dearborn Farms 1. 
APPENDIX 1

\section{GEOTHERMAL WELL STATUS \\ (from Palmer, 1975)}

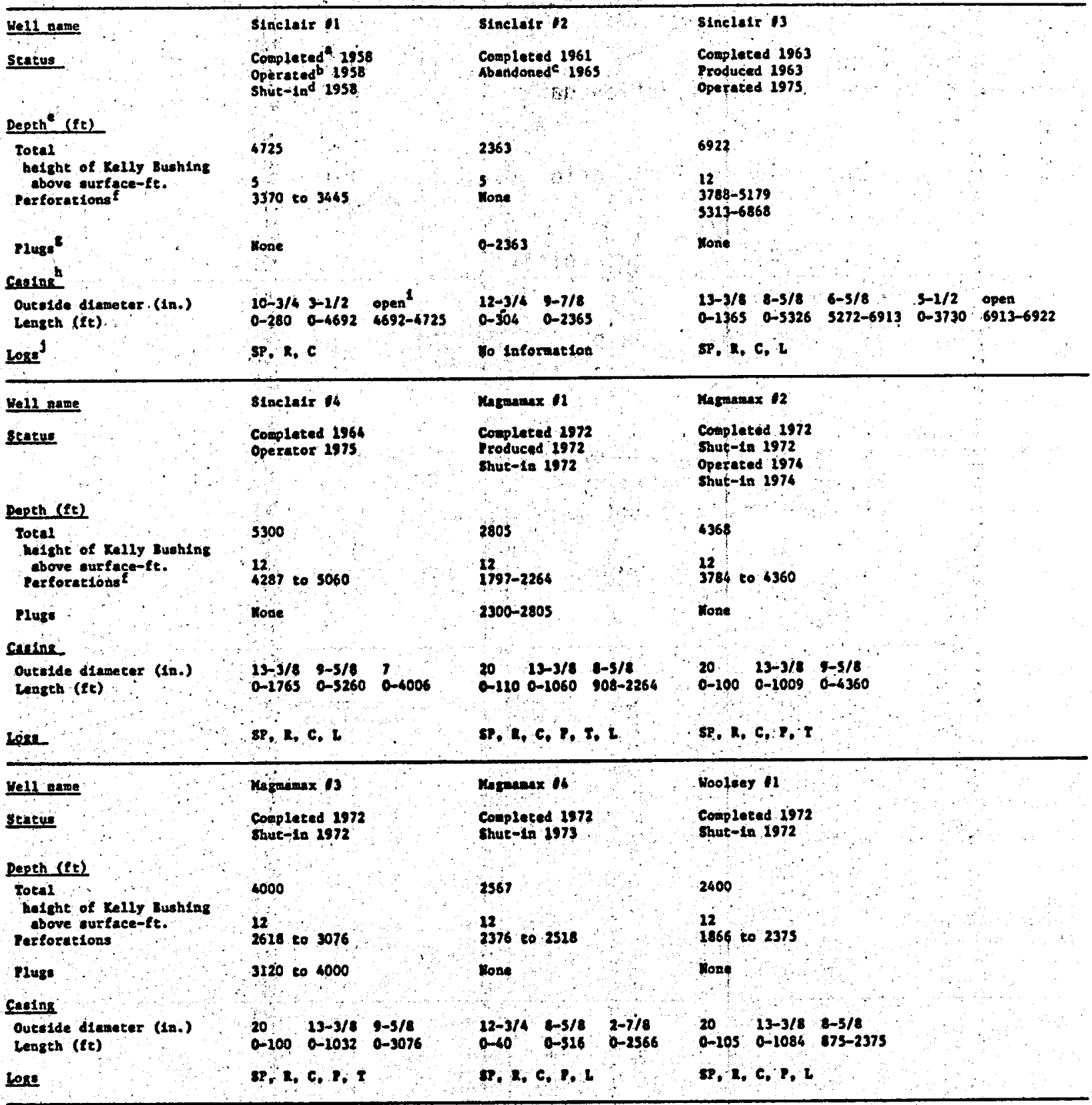




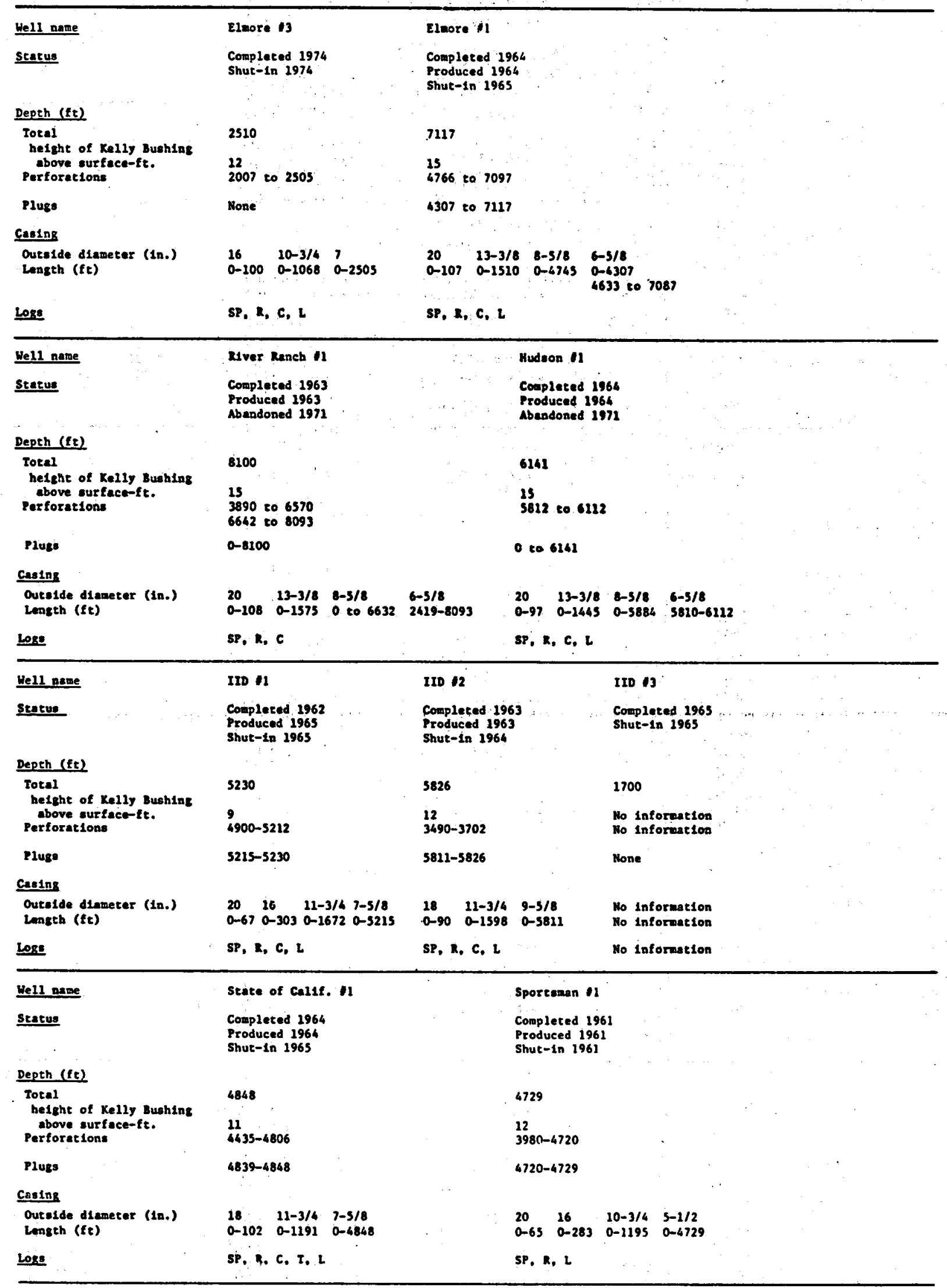




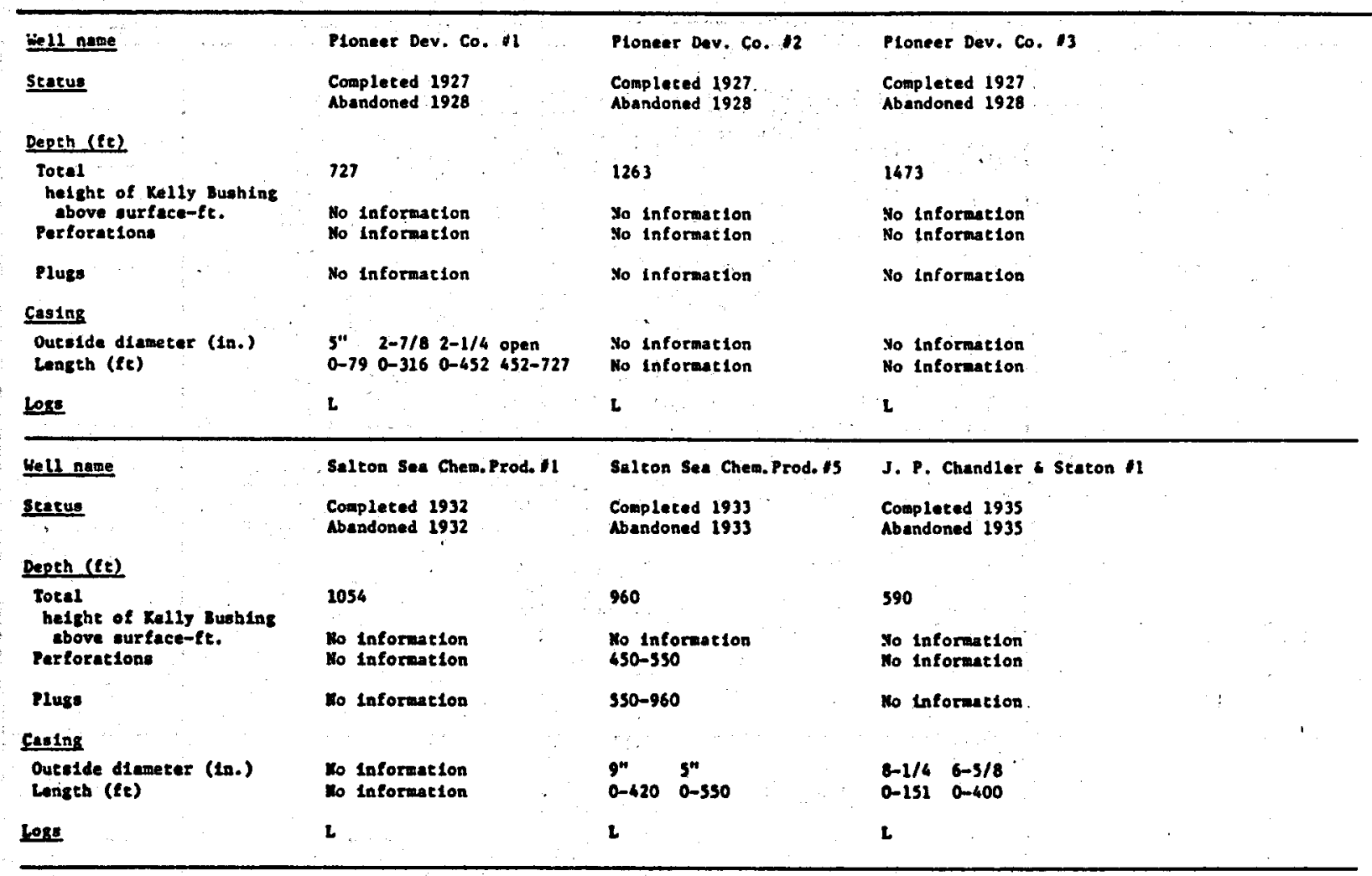

The drilling has been completed at the intended depth.

The rell is or has been flowed within the pase rear.

The vell is Inoperative and the borehole is plusged.

The vellhead is closed but the borehole is not plugged:

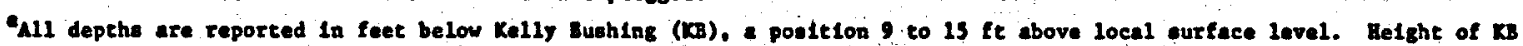

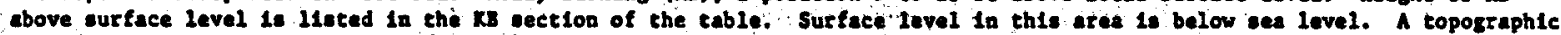
ap of the SSGF area is included (Fis. 2).

Fistied by the depth of the perforated eection and generally represent production zones for each well.

Lleted by. the depth of the plusged section and represent closed sections of the borehole.

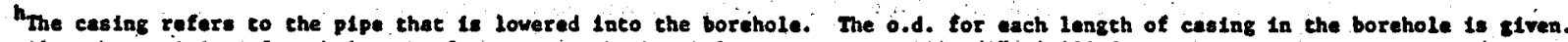
Also the position of each length of casing in the borehole Is upplied: 10-3/4", 0-280 ft aeans that the $0 . d$, is 10-3/4 In. wide and the length of pipe with that diameter extends $280 \mathrm{ft}$ below KR.

'The vord "open" weans that the borahole does not have any plpe.

Jogs avallable for each borahole: SP - helf potential, k - resiseivity, C - conductance, L - 11thology, P - preseure, T - temperature. 


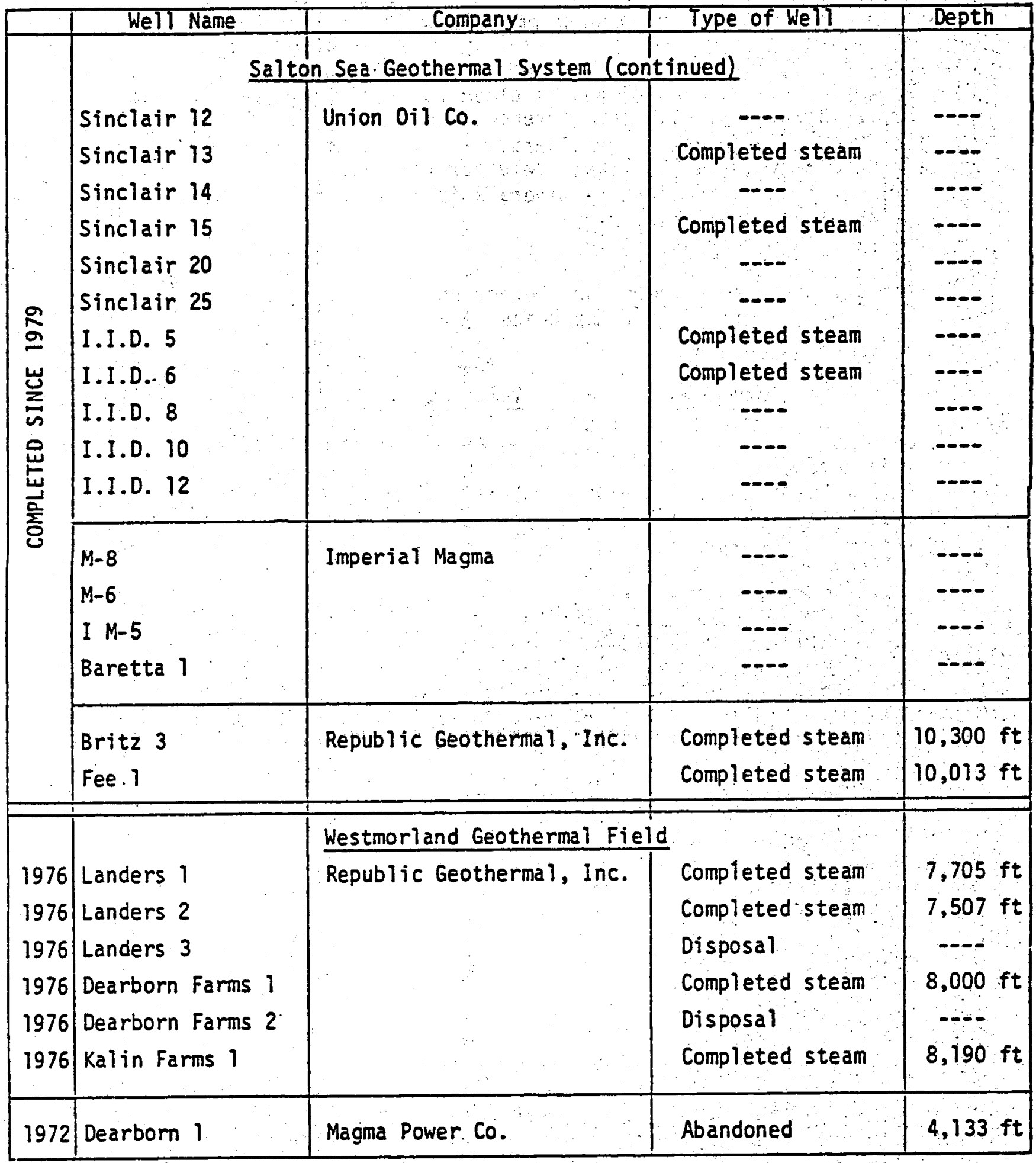


Note: The fdentification of discrete minerais in polymineralic bulk samples by $x$-ray diffraction techniques is often complicated by low mineral quantities and/or major $x$-ray peak interference. This occurs in the Salton Sea and Westmorland geothermal systems for minerals kaol inite, two undifferentiated chlorite types, anhydrite, and alkall feldspar from $24.95^{\circ} 2 \theta$ to $25.65^{\circ} 2 \theta$. Thus, differentiation between these minerals is difficult and somewhat tenuous in this $2 \theta$ range.

X-Ray Diffraction: Mineral and Detection Limits and Standard Errors for Appendices 2 and 3

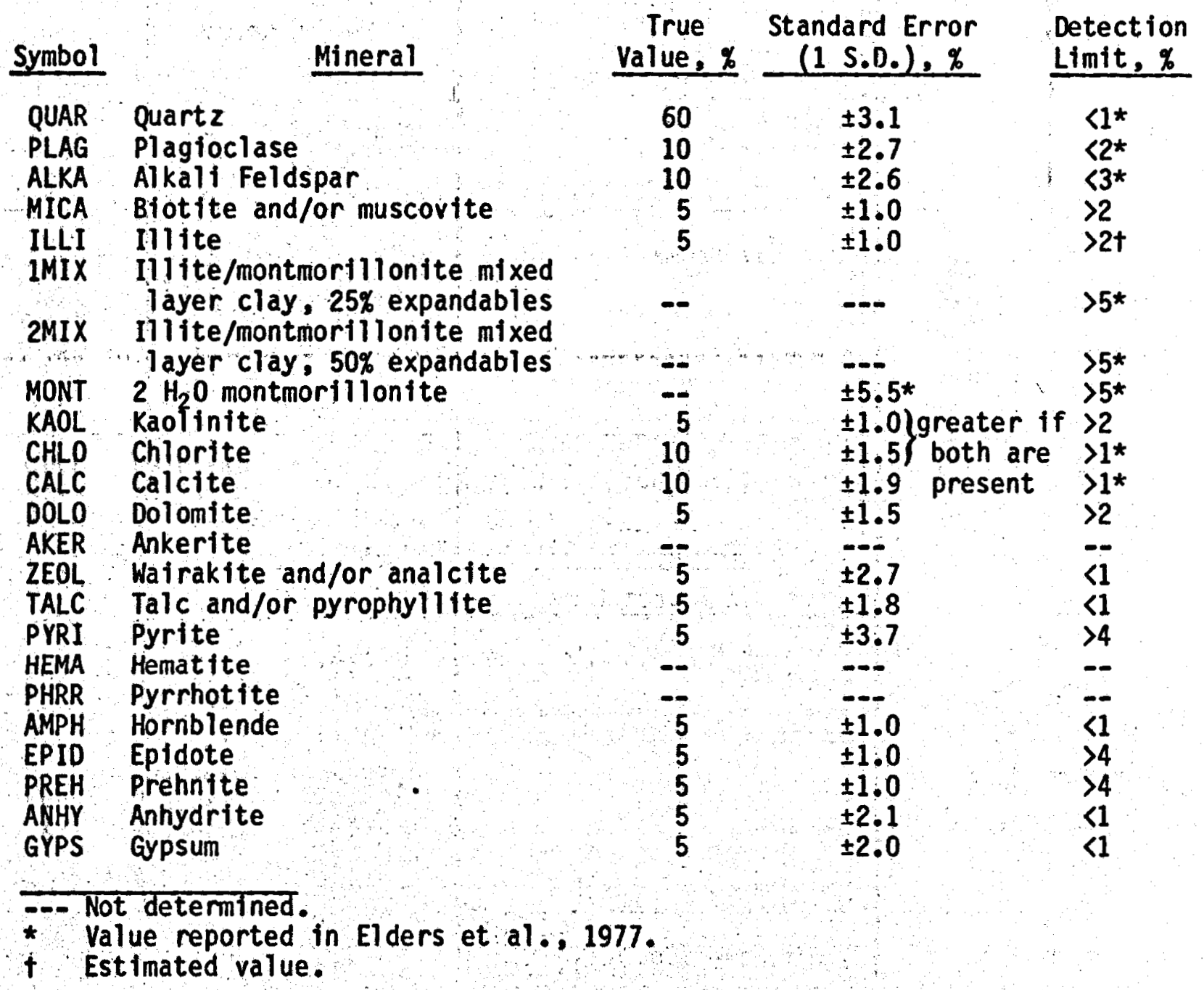


SHALE X-RAY DIFFRACTION DATA

Well Magmamax 2

Selected Bulk Shales

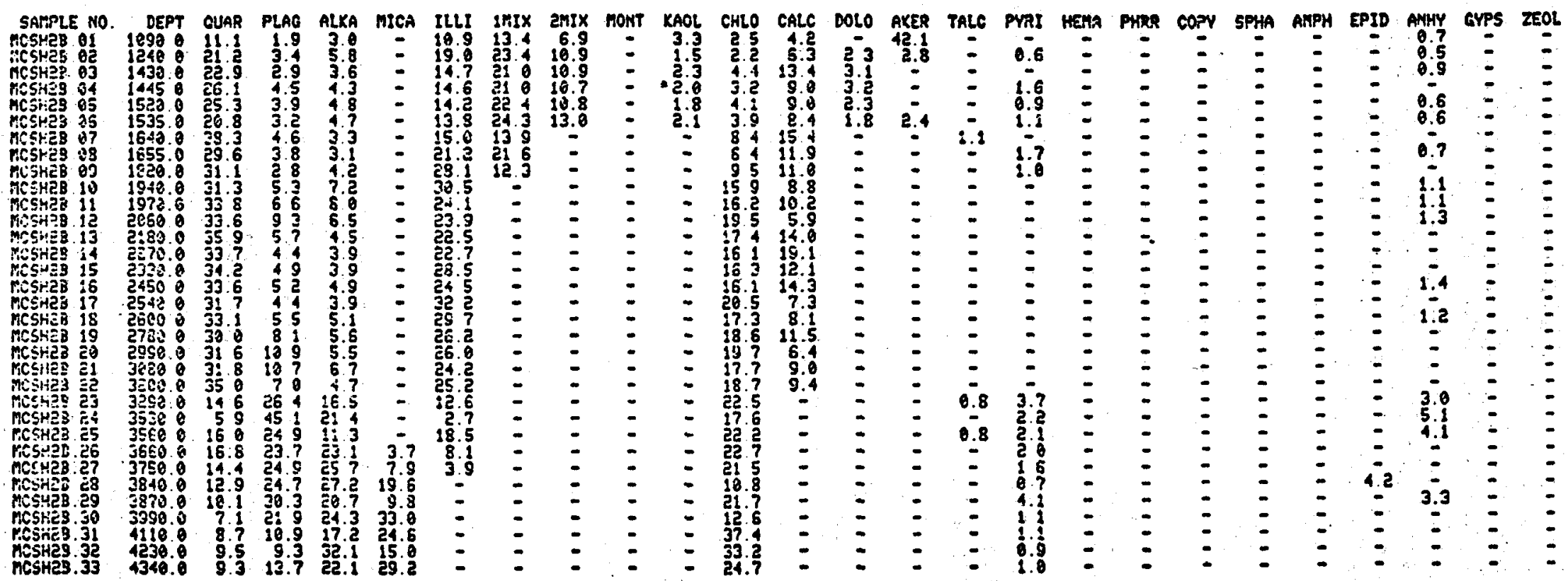

(McDowe11, unpublished data) 
Well Magmamax 3

Selected Bulk:Shales

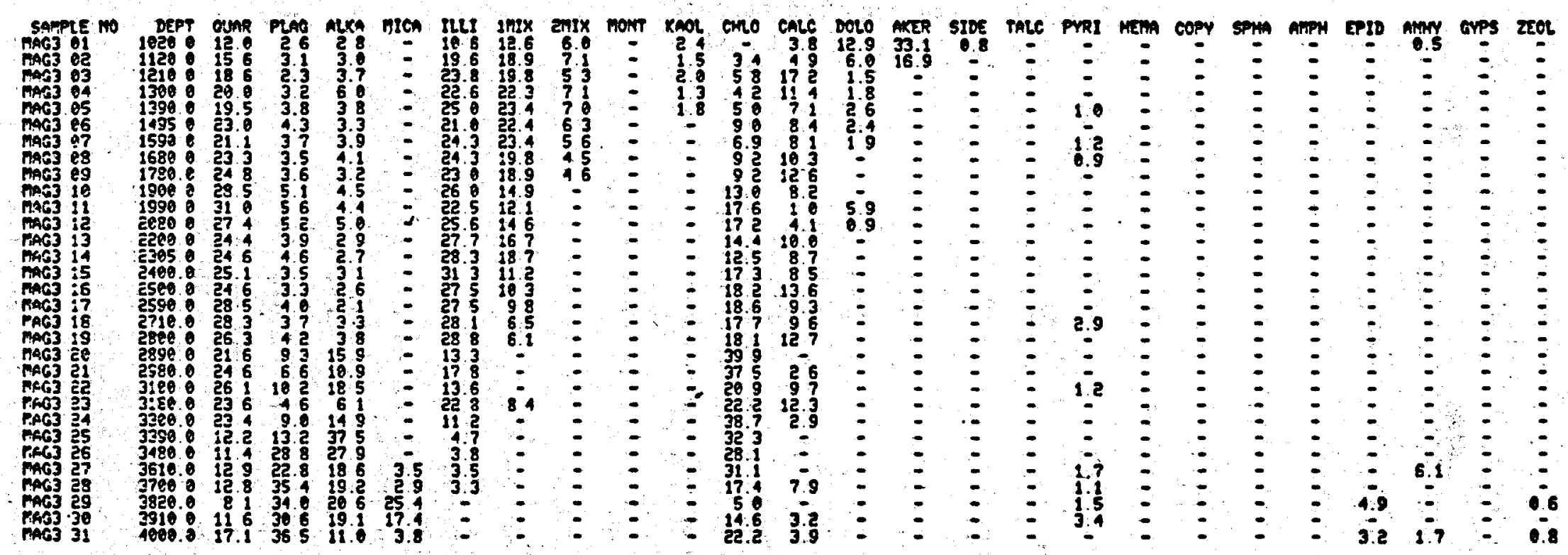




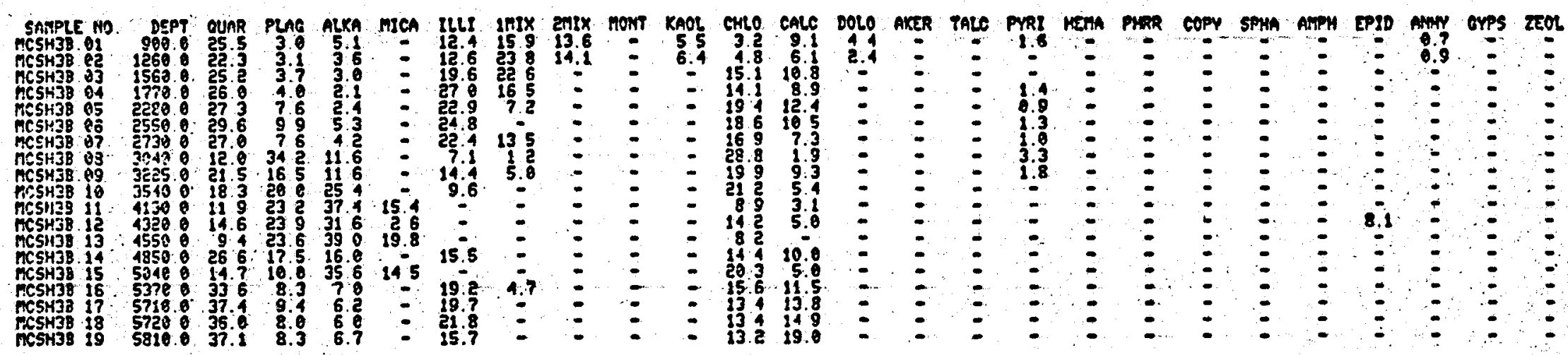

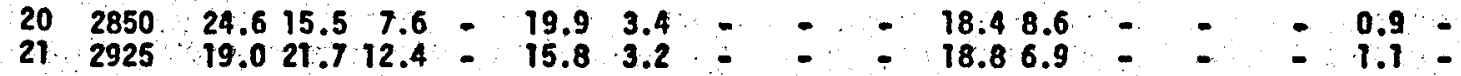

Wel1 Elmore 1

Selected Bulk Shales:

\begin{tabular}{|c|c|c|c|c|c|c|c|c|c|c|c|c|c|c|c|c|c|c|c|c|c|c|c|c|c|}
\hline 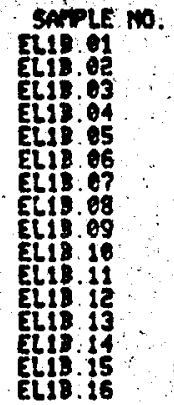 & 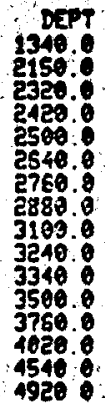 & $\begin{array}{l}04 \\
26: 2 \\
31.5 \\
24.8 \\
237 \\
29.3 \\
27.1 \\
181 \\
24.1 \\
27.2 \\
28.1 \\
31.6 \\
18.0 \\
22.2 \\
19.6 \\
22.0 \\
25 .\end{array}$ & $\begin{array}{l}P 2 n \\
3.4 \\
4.4 \\
1.3 \\
3.6 \\
5.2 \\
9.6 \\
22.2 \\
19.6 \\
12.8 \\
15.2 \\
13.8 \\
14.6 \\
12.9 \\
11.4 \\
17.8 \\
19.6\end{array}$ & $\begin{array}{r}\text { ALK } \\
3.0 \\
4.2 \\
2.1 \\
3.5 \\
4.1 \\
5.4 \\
86 \\
11.2 \\
8.6 \\
8.6 \\
6.8 \\
27.8 \\
19.2 \\
28.9 \\
13.4 \\
14.2\end{array}$ & $\begin{array}{r}\text { MICA } \\
= \\
= \\
= \\
= \\
= \\
= \\
=\end{array}$ & $\begin{array}{l}14.1 \\
16.6 \\
33.8 \\
25.2 \\
37.3 \\
31.3 \\
39.5 \\
21.4 \\
12.3 \\
21.6 \\
19.6 \\
15.7 \\
2.7 \\
11.1 \\
21.7 \\
15.1 \\
25.4\end{array}$ & $\begin{array}{c}\min x \\
23.3 \\
-12.3 \\
\vdots\end{array}$ & $\begin{array}{c}2 \ln 1 x \\
12.1 \\
= \\
= \\
= \\
= \\
= \\
=\end{array}$ & $\begin{array}{l}\text { nom } \\
= \\
= \\
= \\
= \\
= \\
= \\
= \\
=\end{array}$ & $\begin{array}{l}\text { RAOL } \\
2.3 \\
-2\end{array}$ & $\begin{array}{r}\text { crico } \\
18.2 \\
18.2 \\
21.5 \\
22.5 \\
20.5 \\
18.8 \\
21.8 \\
14.2 \\
17.8 \\
15.9 \\
16.5 \\
33.2 \\
29.1 \\
19.3 \\
27.3 \\
11.6\end{array}$ & $\begin{array}{l}\text { catc } \\
10.5 \\
7.2 \\
9.0 \\
8.4 \\
9.8 \\
7.8 \\
4.5 \\
15.8 \\
11.0 \\
11.4 \\
13.3 \\
2.4 \\
3.9 \\
4.5 \\
4.4 \\
4.3\end{array}$ & $\begin{array}{l}\infty \\
3: 6\end{array}$ & MER & SRDE & & & rema & $T^{\prime \prime R R}$ & & & & & & orp \\
\hline
\end{tabular}


Well Sinclair 4

Selected Bulk Shales

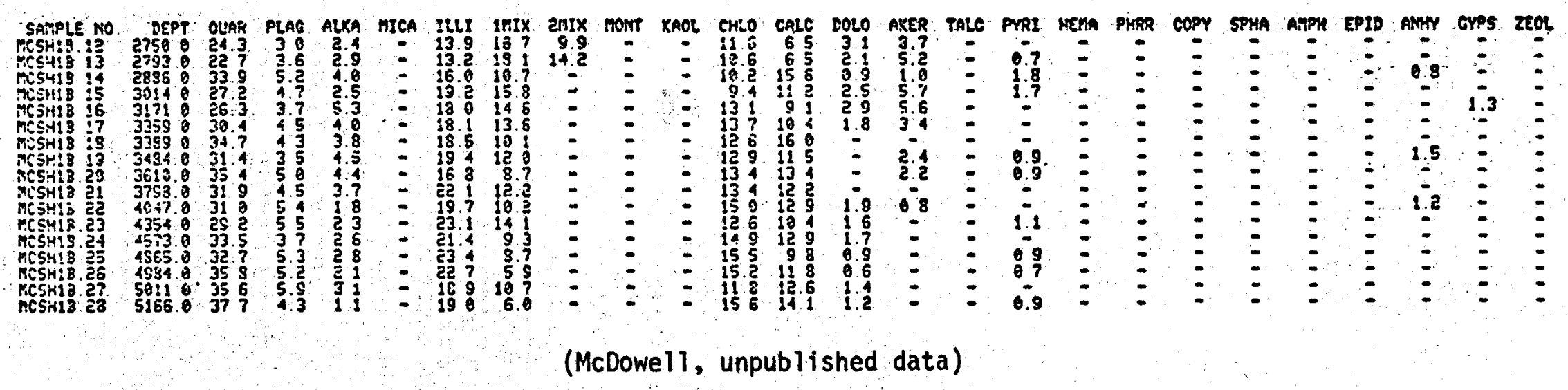

Well Sinclair 3

Selected Bulk Shales

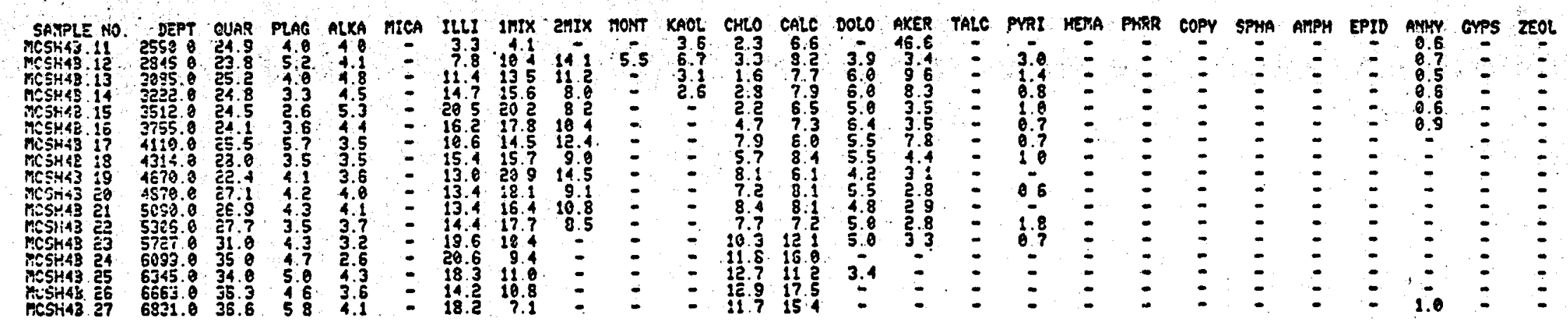

(McDowe11, unpublished data) 
Well Britz 3

Selected Bulk Shales

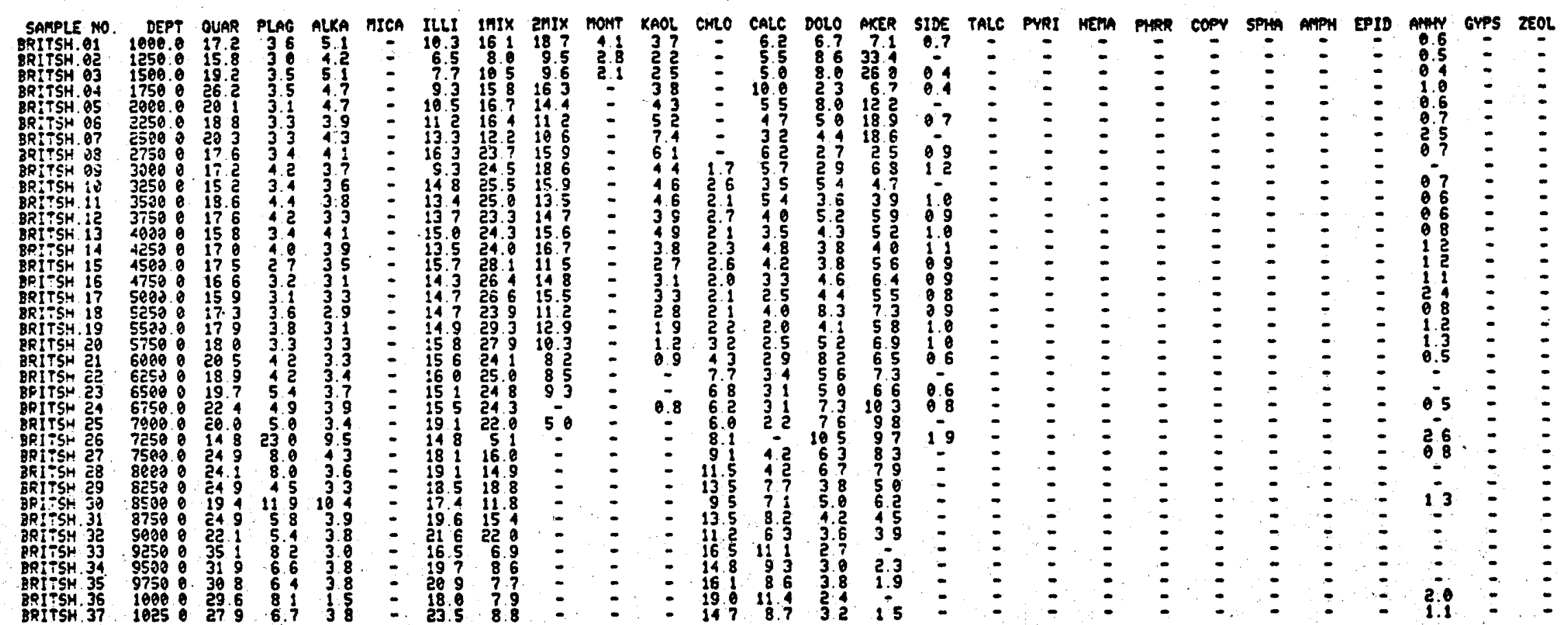


Well Landers 1

Selected Bulk Shales

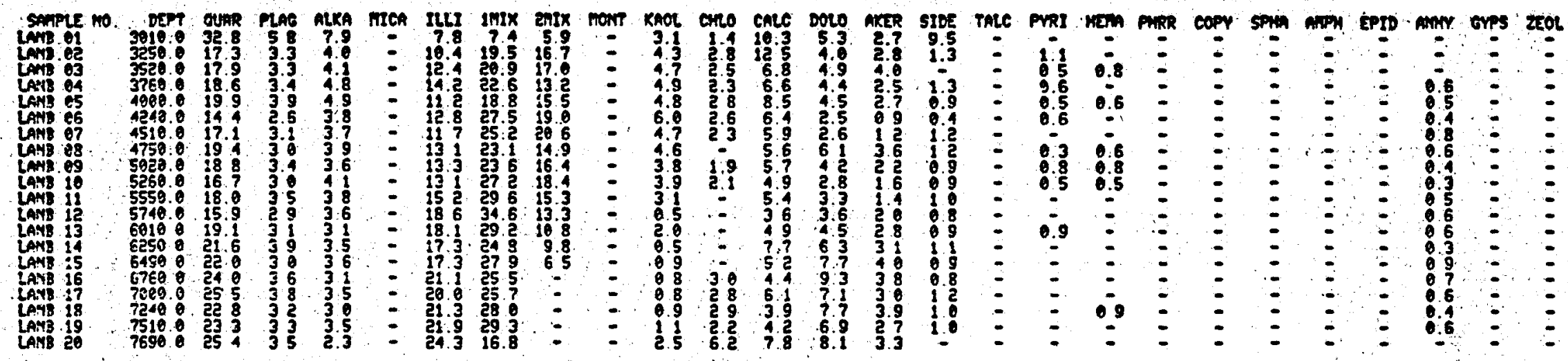

Well Kal in Farms 1

Selected Bulk Shales

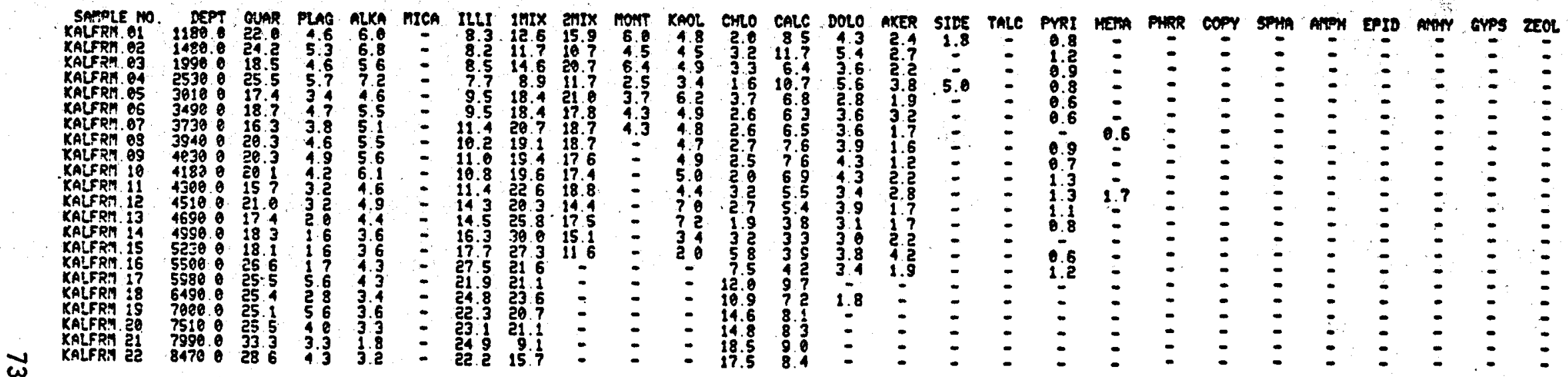




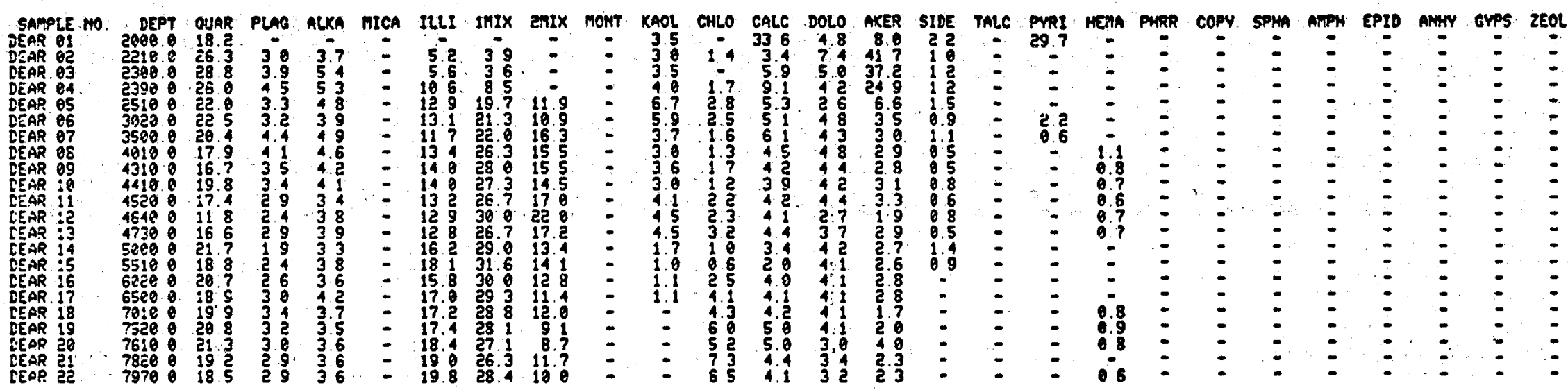

We 1$]$ Landers 2

Selected Bulk Shales

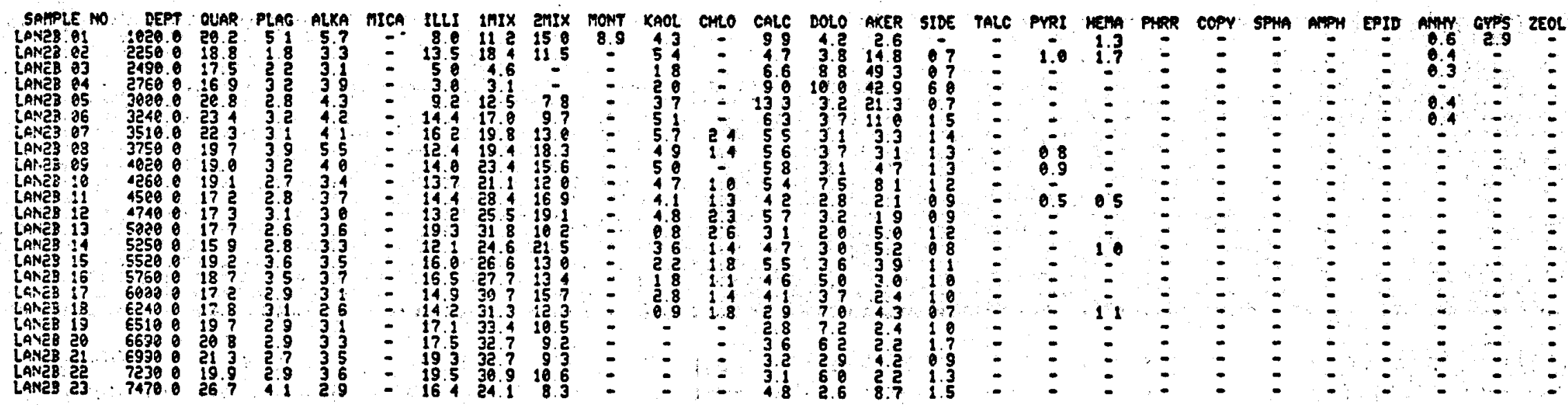


Well River Ranch 1

Selected Bulk Shales

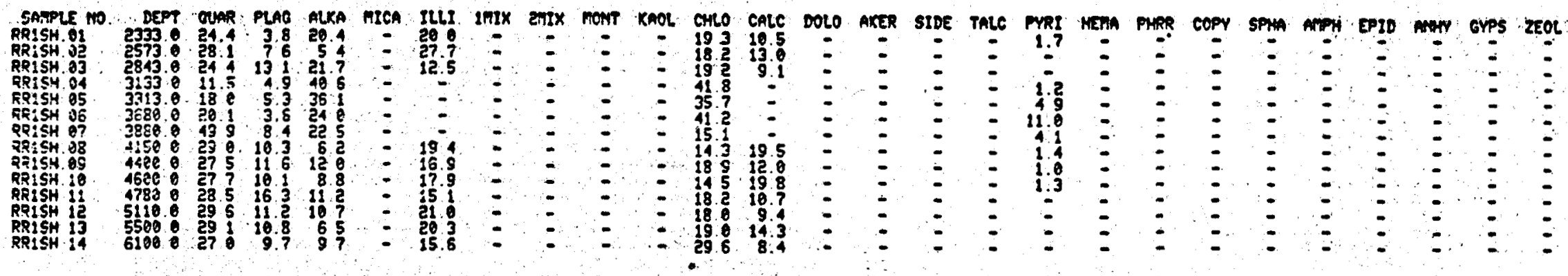

Well Woolsey 1

Selected Bulk Shales

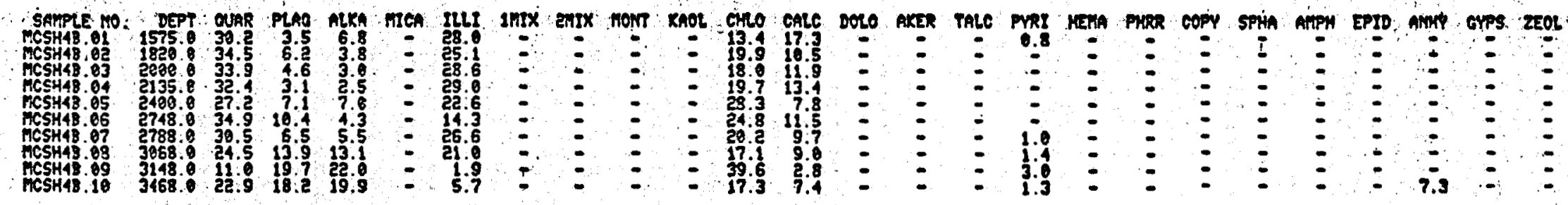

(McDowe11; unpublished data)

Well Elmore 3

Selected Bulk Shales

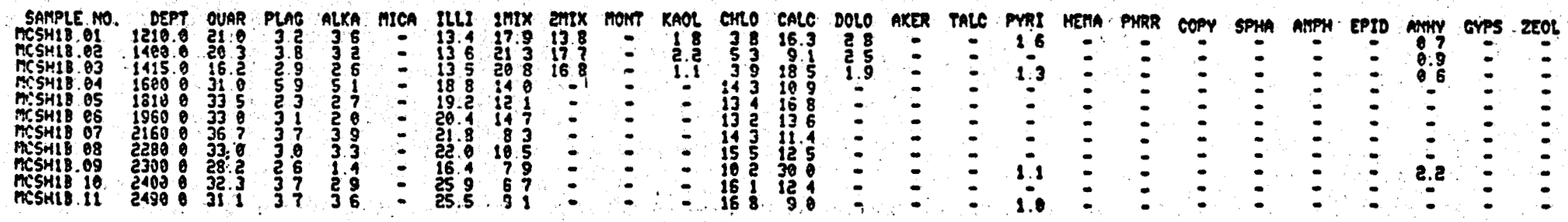


SANDSTONE X-RAY DIFFRACTION DATA

Well Magmamax 2

Selected Bulk Sandstones

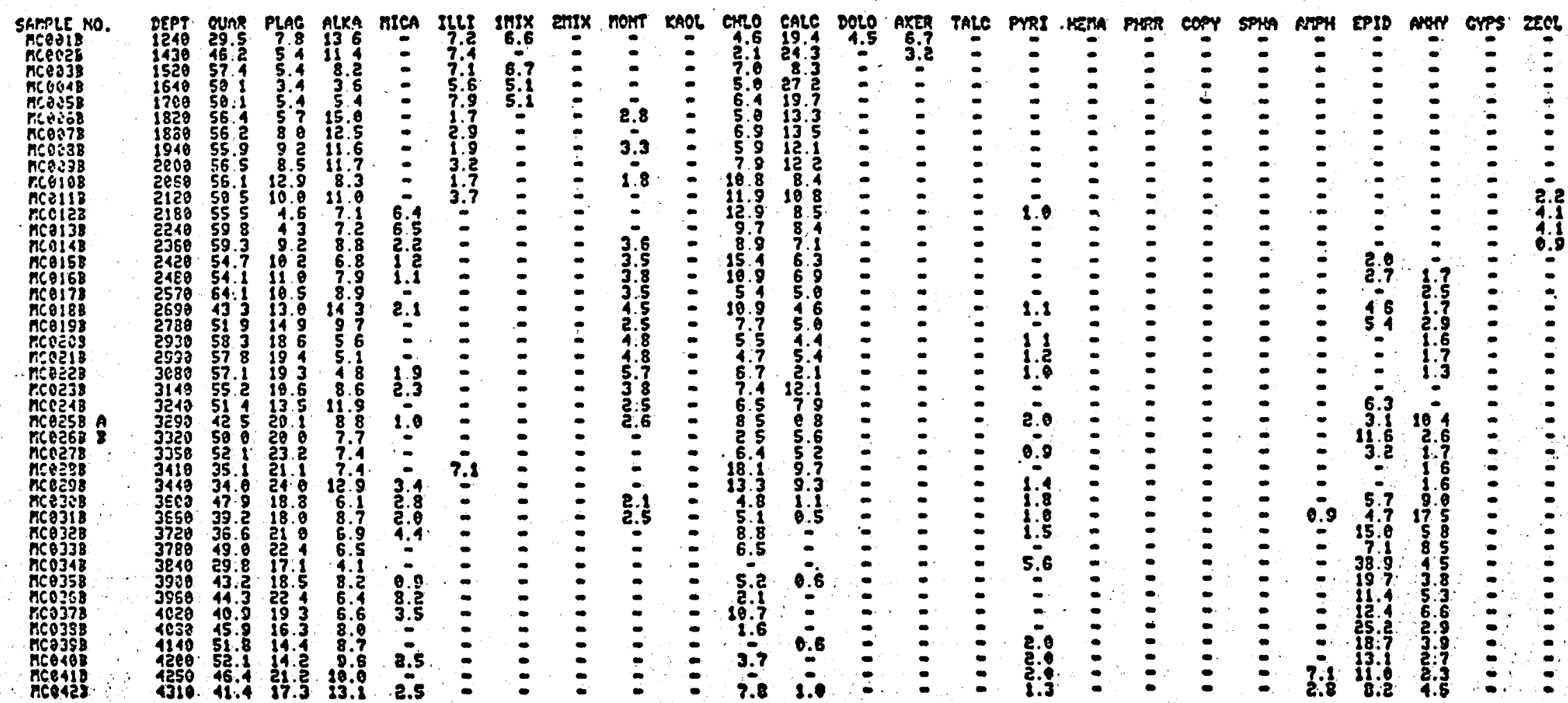

(McDowell, unpublished data) 
Well Magmamax 3

Selected Bulk Sandstones

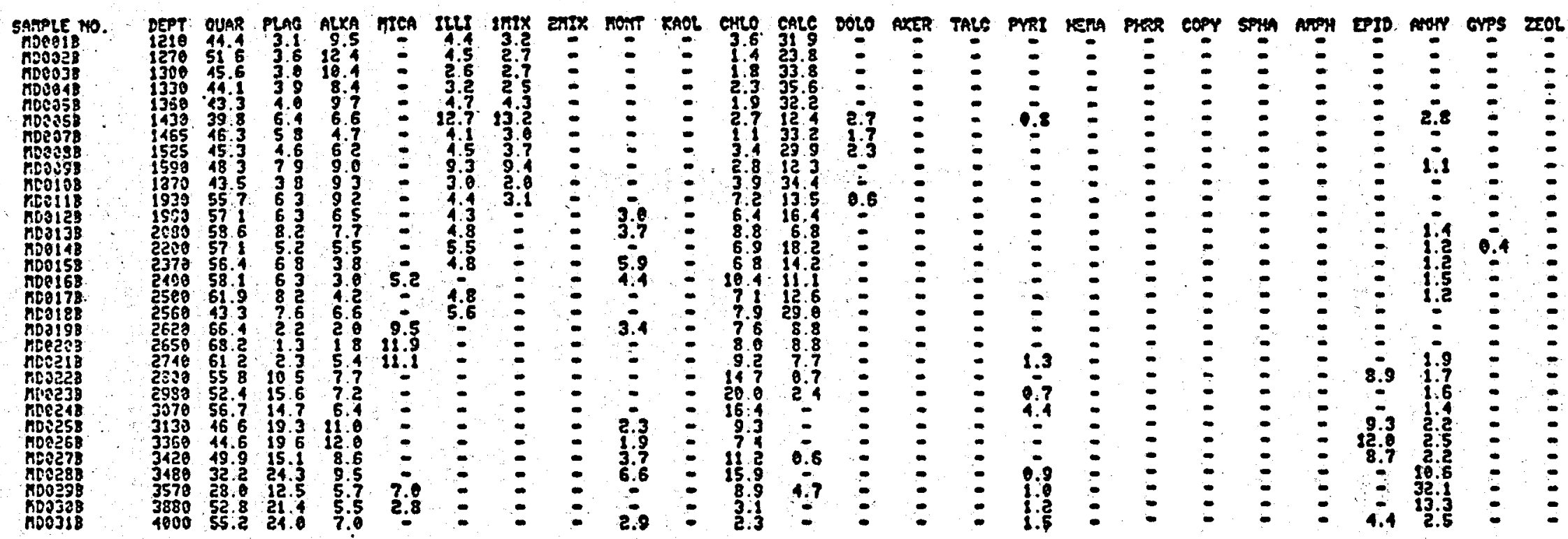

(McDowell, unpublished data)

Well Sinclair 4

Selected Bulk Sandstones

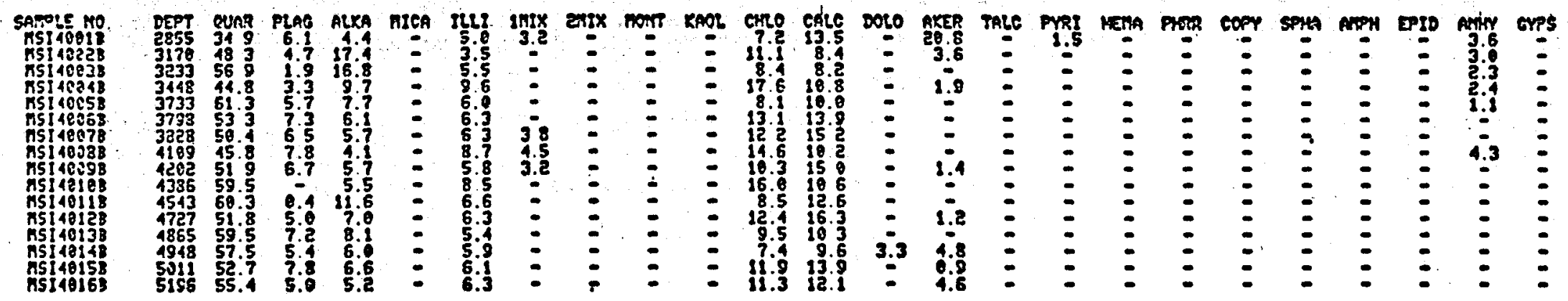

(McDowe11, unpubl ished data) 
Well I.I.D. 2

Selected Buik Sandstones

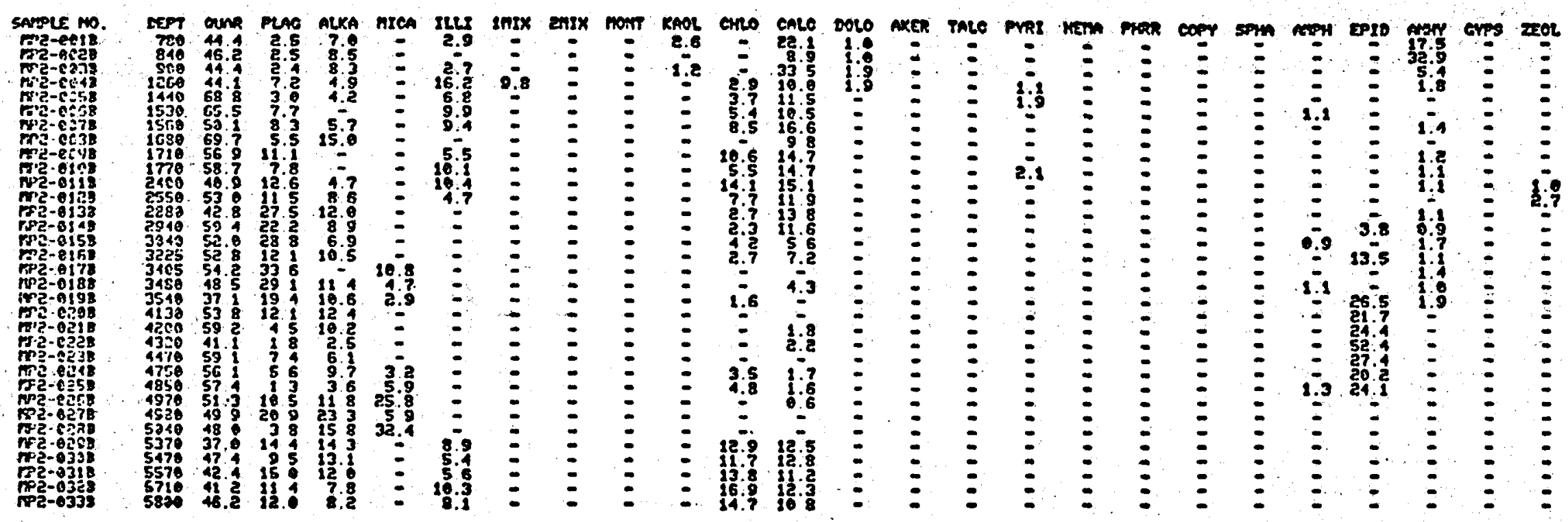

(McDowell, unpublished data) 
Well Sinclair 3

Selected Bulk Sandstones
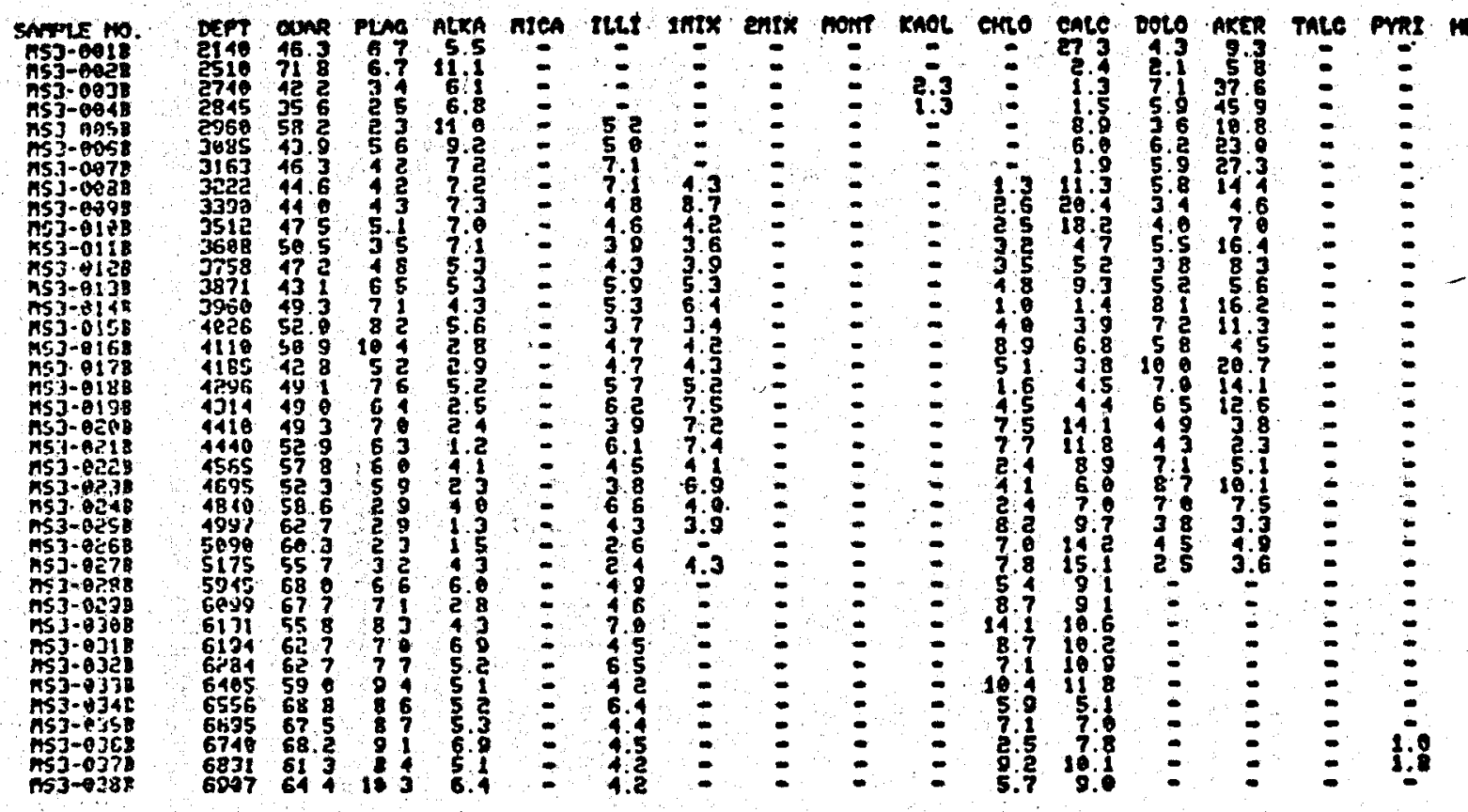

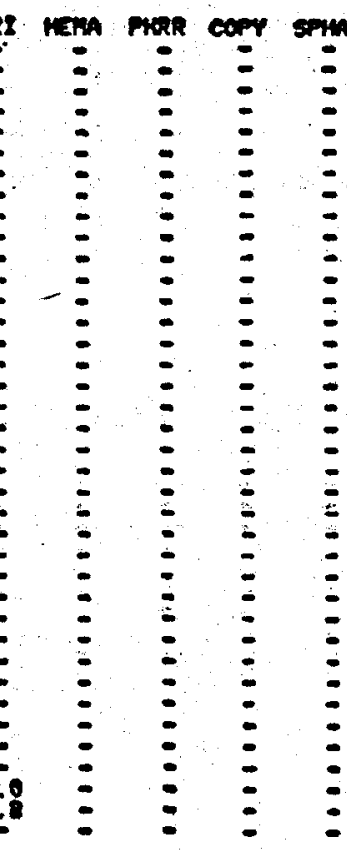

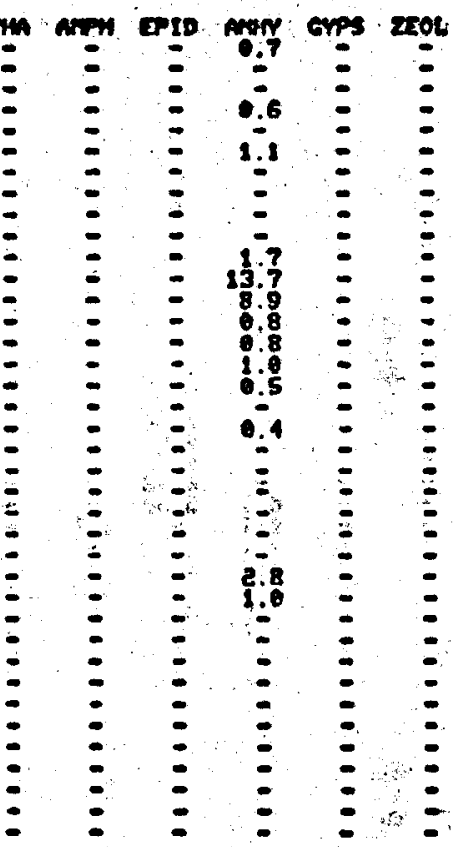

(McDowel1, unpublished data) 


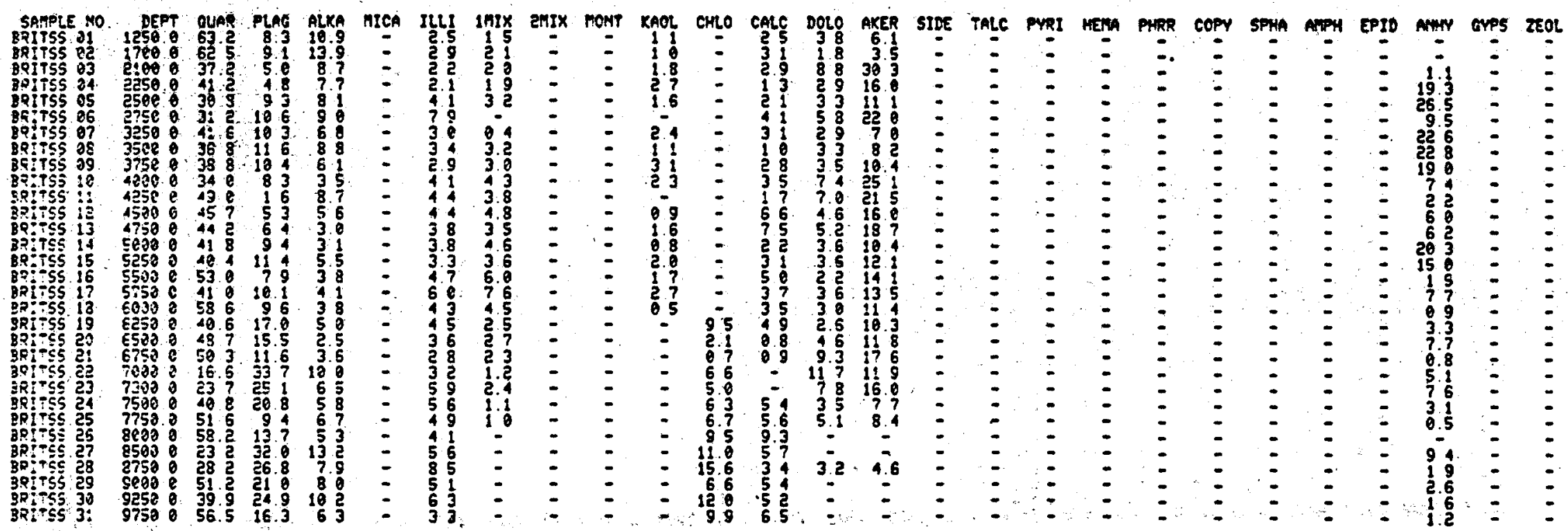

Wel1 Landers 1

Selected Bulk Sandstones

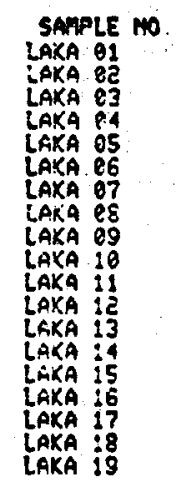
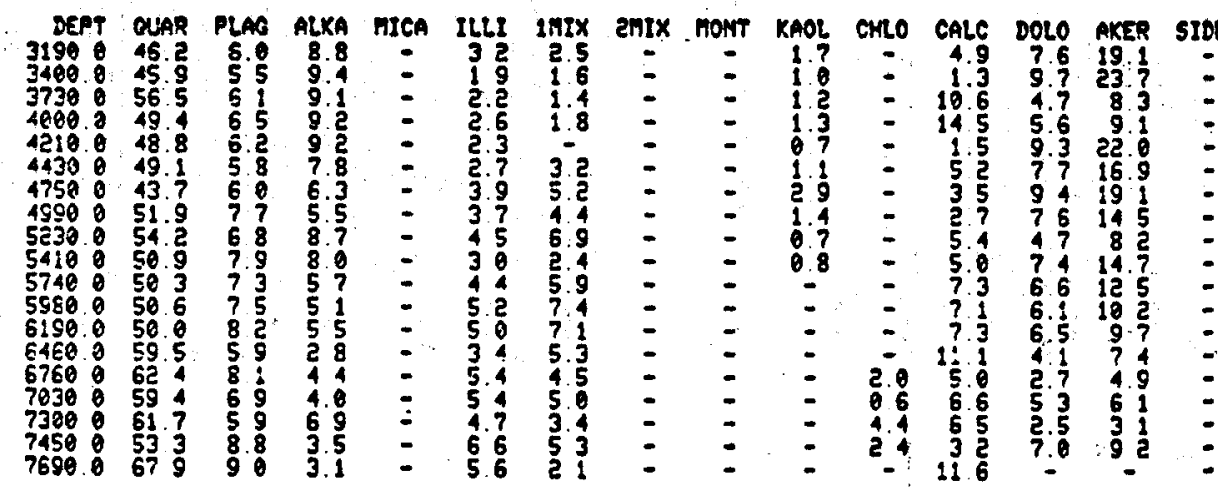

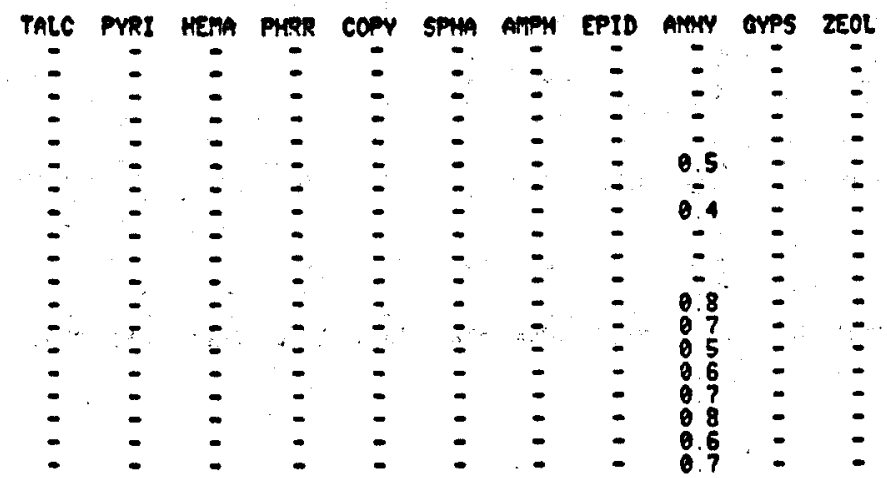


Well Kal in Farms 1

Selected Bulk Sandstones



Well River Ranch 1

Selected Bulk Sandstones

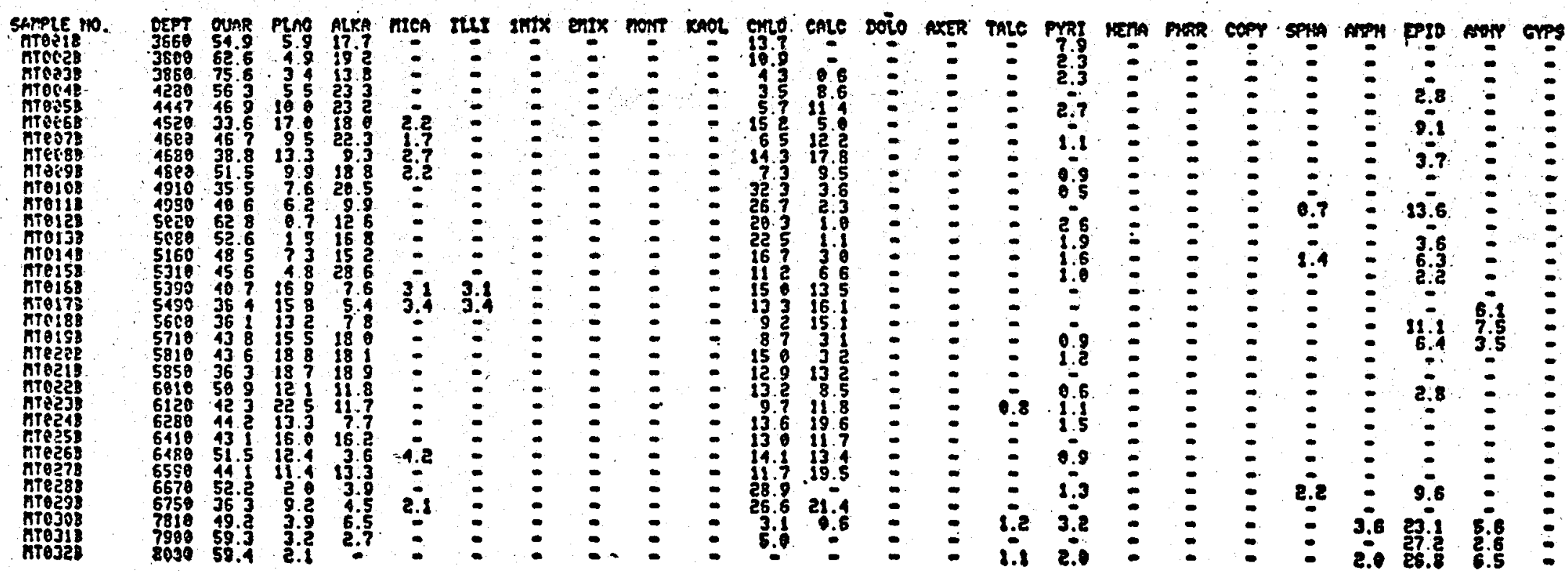

(McDowe11, unpublished data) 


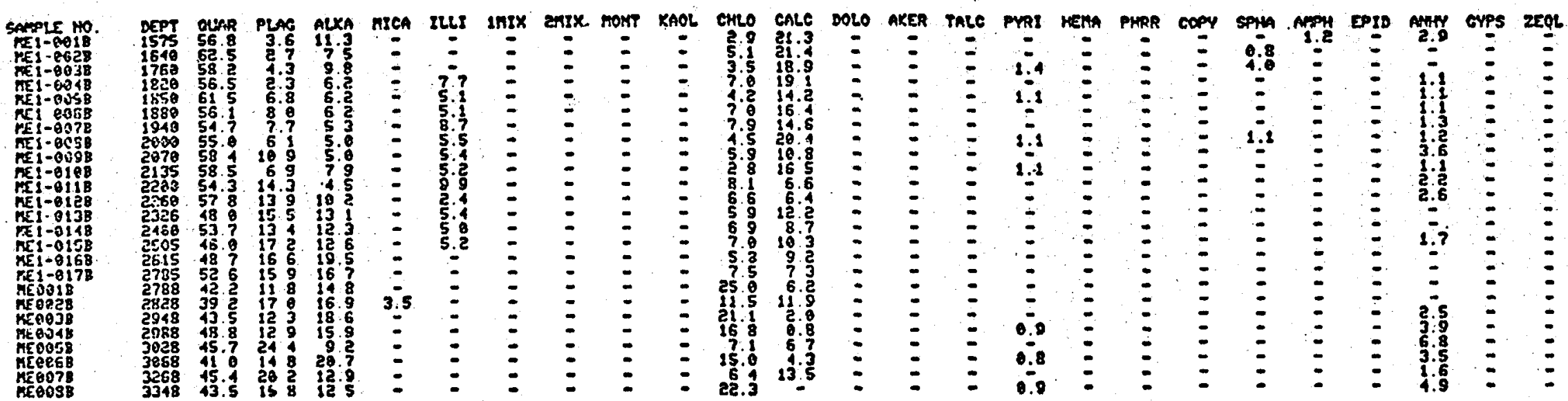

(McDowell, unpublished data)

Well Elmore 3

Selected Bulk Sandstones
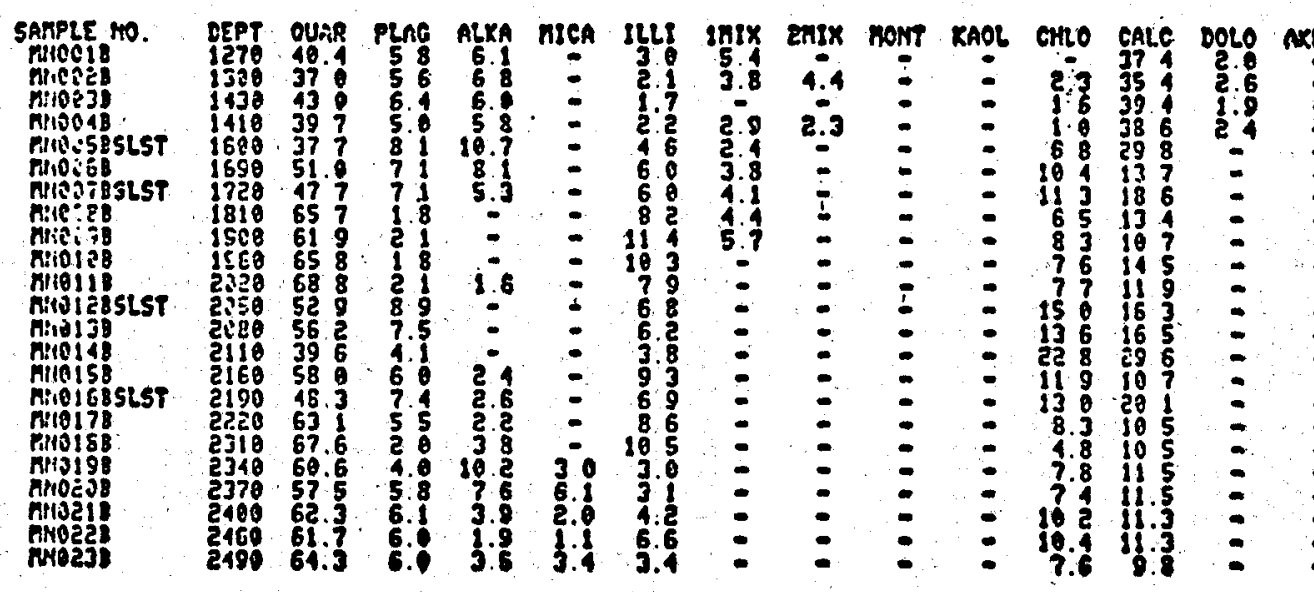

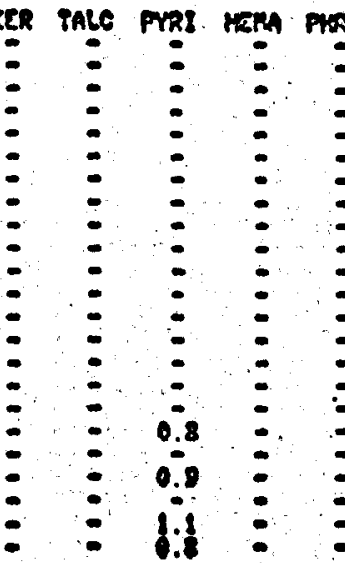

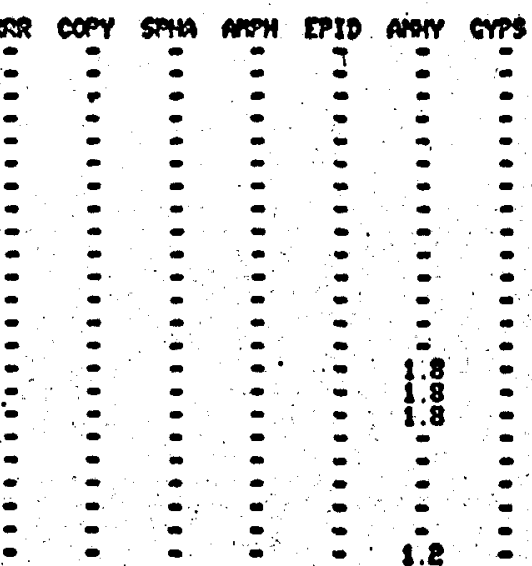

(McDowe 11, unpublished data) 


\section{APPENDIX 4}

RECONNAISSANCE PETROGRAPHIC DESCRIPTION OF WELL BRITZ \#3 - SALTON SEA GEOTHERMAL SYSTEM

(Sampled Interval $4250-10,250 \mathrm{ft}$ )

The sandstones of Britz \#3, classified as subarkose to sublitharenites, are medium- to fine-grained with largely subangular to subrounded detrital clasts. Varying from moderately to poorly sorted, these sandstones are composed of detrital quartz, plagioclase, K-feldspar, biotite, chlorite, muscovite, and the clay minerals (montmorillonite, illite, and kaolinite, Appendix 3). Also present are detrital clasts of volcanic origin, siltstones, and chert. Quartz constitutes approximately $50-75 \%$ of the detrital clasts by volume. These grains are dominantly monocrystalline with occasional undulose and polycrystalline individuals. Intergrowths of anhydrite within quartz clasts sporadically occur throughout the well. The feldspars constitute between $10-20 \%$ of the detrital mineralogy, approximately $50-60 \%$ are microcline and perthitic microcline, with the remainder being plagioclase. The detrital micas, biotite, chlorite, and muscovite, are commonly bent and broken.

The alteration mineralogy includes quartz, calcite, anhydrite, chlorite, pyrite, and microcline (adularia?). Authigenic quart $z$, al though not abundant but found in all of the thin sections examined, usually occurs as optically continuous syntaxial rims on detrital quartz. Epitaxial quartz overgrowths on detrital feldspar and lithic clasts are also sporadically found. The major cementing mineral in this well is calcite. This authigenic mineral occurs as micritic to interlocking sparry cement that encloses sand remnants. Grain size and porosity appear to control the type of cementation; the more coarse-grained sandstones contain the larger crystals; whereas the finer grained, more poorly sorted sandstones contain the micritic cement. Often associated with calcite are euhedral colorless sperulites (mostly occurring in veins) to pore-filling material of anhydrite. Anhydrite is identified by its high, second order birefringence and cubic cleavage. Occasionally, anhydrite appears to be replacing derital clasts. The sheet silicate, chlorite, pleochroic in deepgreen to green colors, is predominantly present below $7000 \mathrm{ft}(2133 \mathrm{~m})$. The chlorite is likely an alteration of detrital kaolinite (Muffler and White, 1969). Euhedral to subhedral pyrite is found in all intervals sampled. Microcline (adularia?) is probably the al teration product of plagioclase caused by K-metasomatism. This K-feldspar is present below $7000 \mathrm{ft}(2133 \mathrm{~m})$. 


\section{APPENDIX 5}

COMPUTATION OF $R_{t}$ AND $R_{X O}$ FROM THE DUAL INDUCTION-LATEROLOG (from Bateman and Konen, 1977b)

$$
\begin{aligned}
& R_{t}=\left(R_{i} \mid d\right)(\text { RatioA) } \\
& \text { where RatioA }=R_{j 1 m}\left((G I D-G I M) /\left(G I D * R_{i 1 d}-G I M * R_{j 1 m}\right)\right) \\
& \text { GID }=0.0960 I-0.34+\text { ALPHA - BETA } \\
& \text { ALPHA }=10[.001(156-53 D I)] \\
& B E T A=10[.001(25 D I-3780)] \\
& G I M=0.01230 I-0.212-0.0037 e^{0.04 D I} \\
& \text { GLL8 }=(D I-20) /(1.21 D I+20)+0.343 \\
& D I=(-B+\sqrt{(B-4.0 A C)}) / 2 A \\
& A=Y-0.52 X-0.46 \\
& B=-33 Y+23 X+90 \\
& C=269 Y+530 X+1589 \\
& Y=\left(R_{L L 8}-R_{i 1 d}\right) /\left(R_{i 1 m}-R_{i 1 d}\right) \\
& X=\left(R_{L L 8}-R_{i 1 d}\right) / R_{i 1 d} \\
& R_{\text {Xo }}=R_{t} * \text { RatioA }
\end{aligned}
$$




\section{APPENDIX 6}

WELL LANDERS 1

SALINITY FROM ARCHIES EQUATION

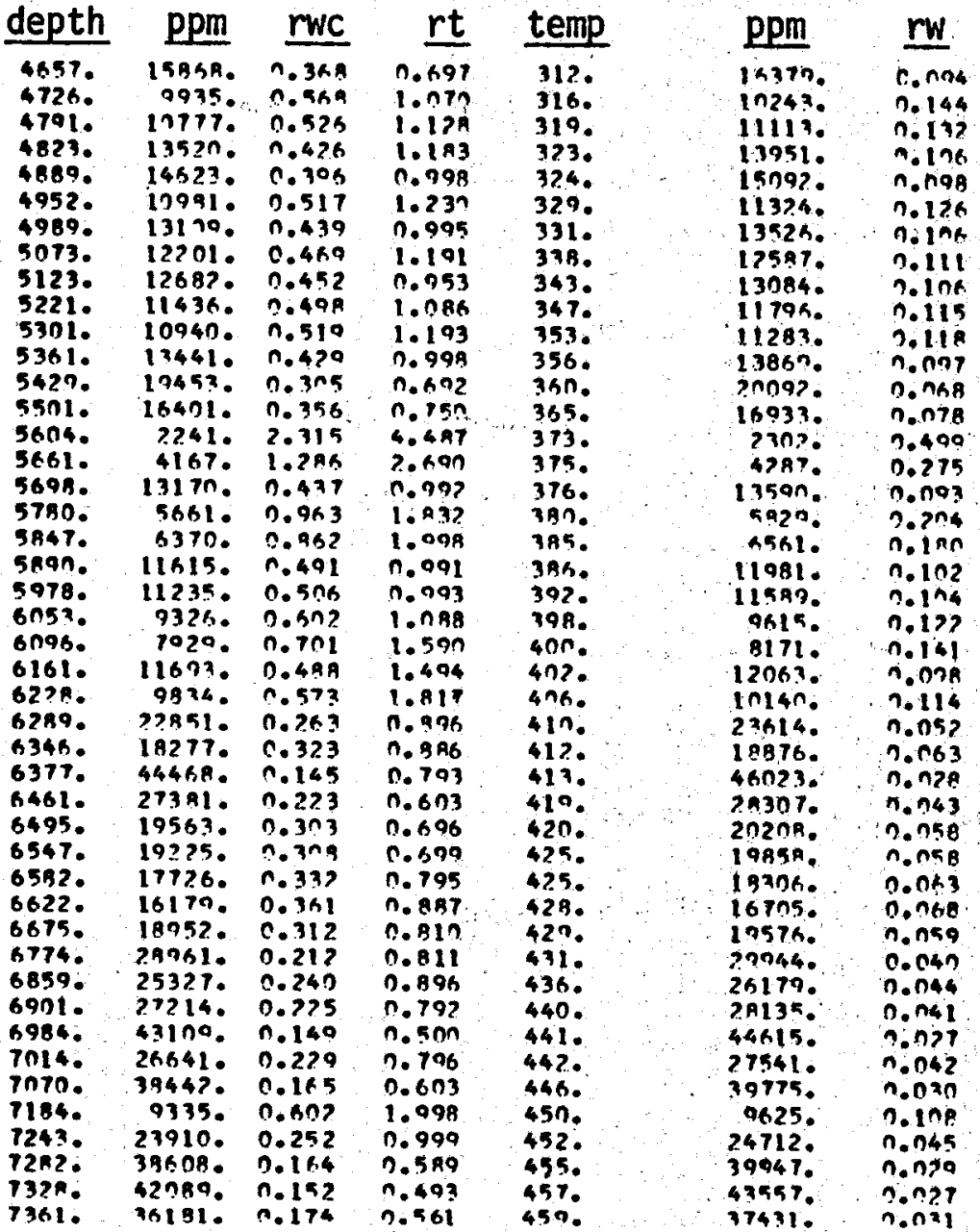


WELL LANDERS 1

SALINITY CALCULATION FROM SP CURVE

CORRECTED TO $75^{\circ} \mathrm{F}$

depth ppm ssp rwc rmf temp

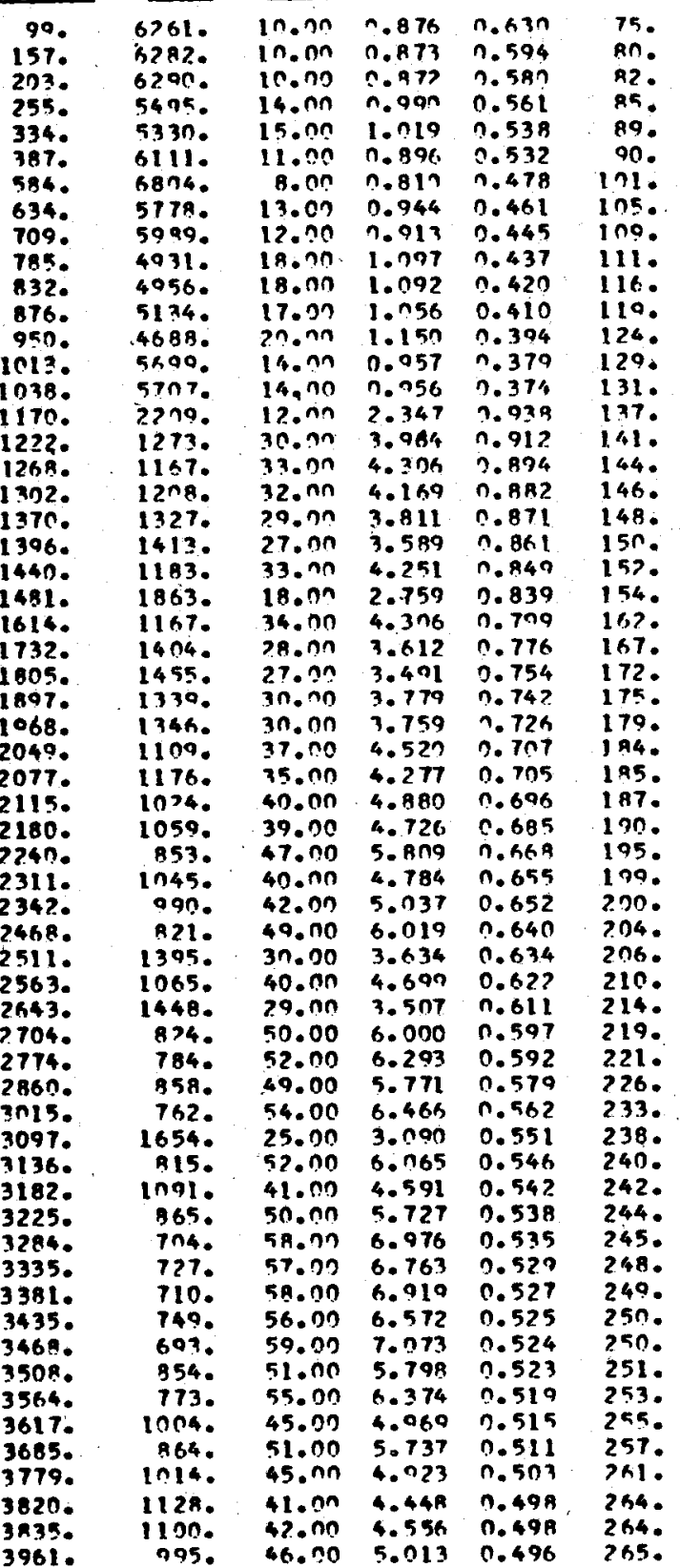

AT FORMATION TEMPERATURE ppm rW

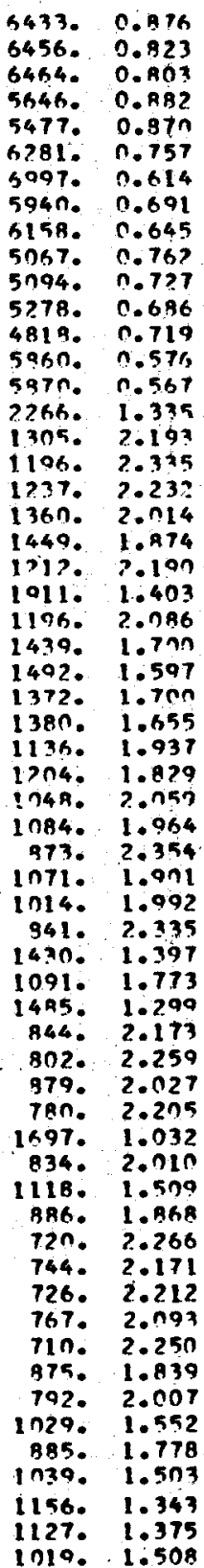


WELL LANDERS 1

SALINITY CALCULATION FROM SP CURVE

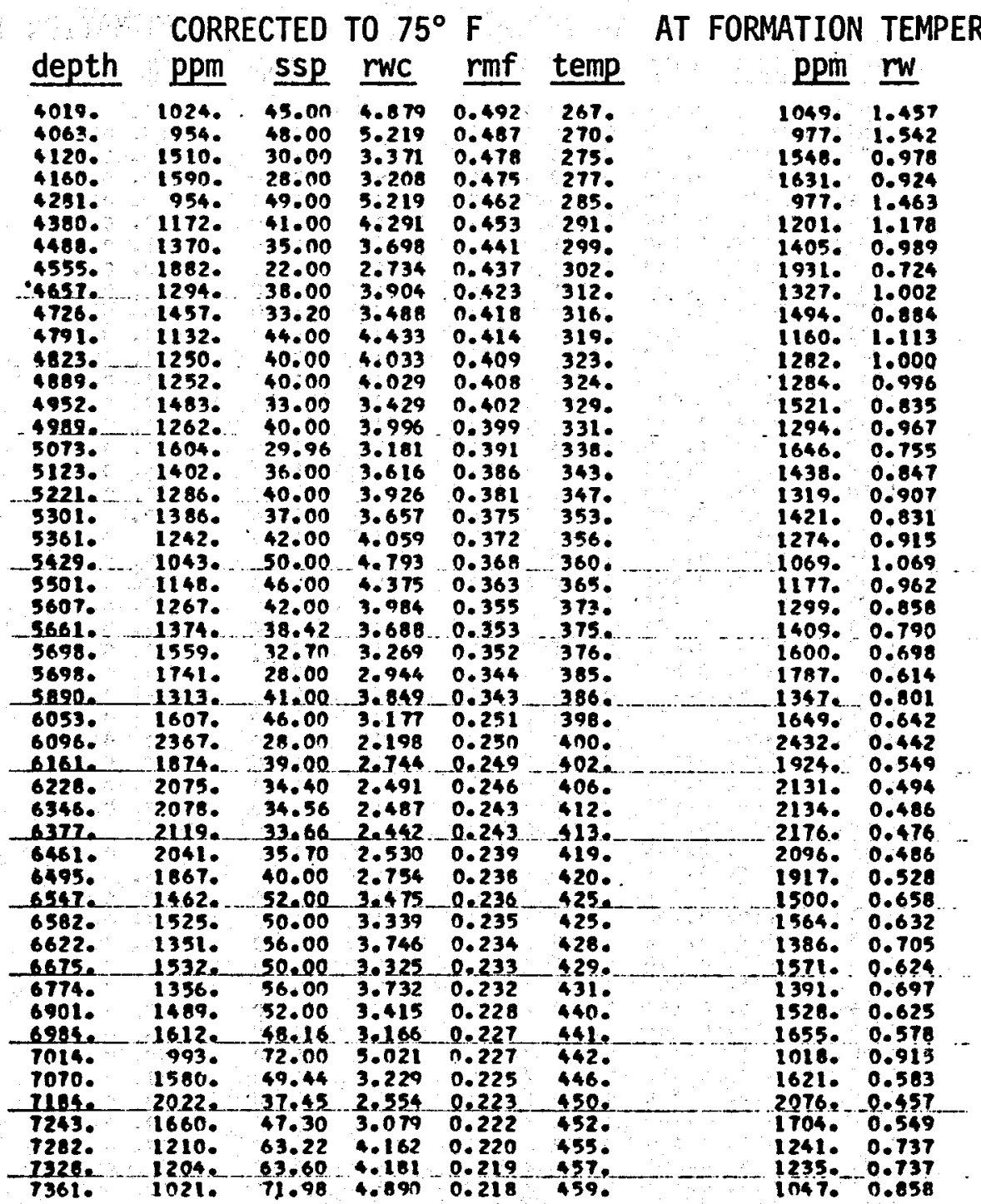




\section{SALINITY CALCULATION FROM FLUSHED ZONE DATA}

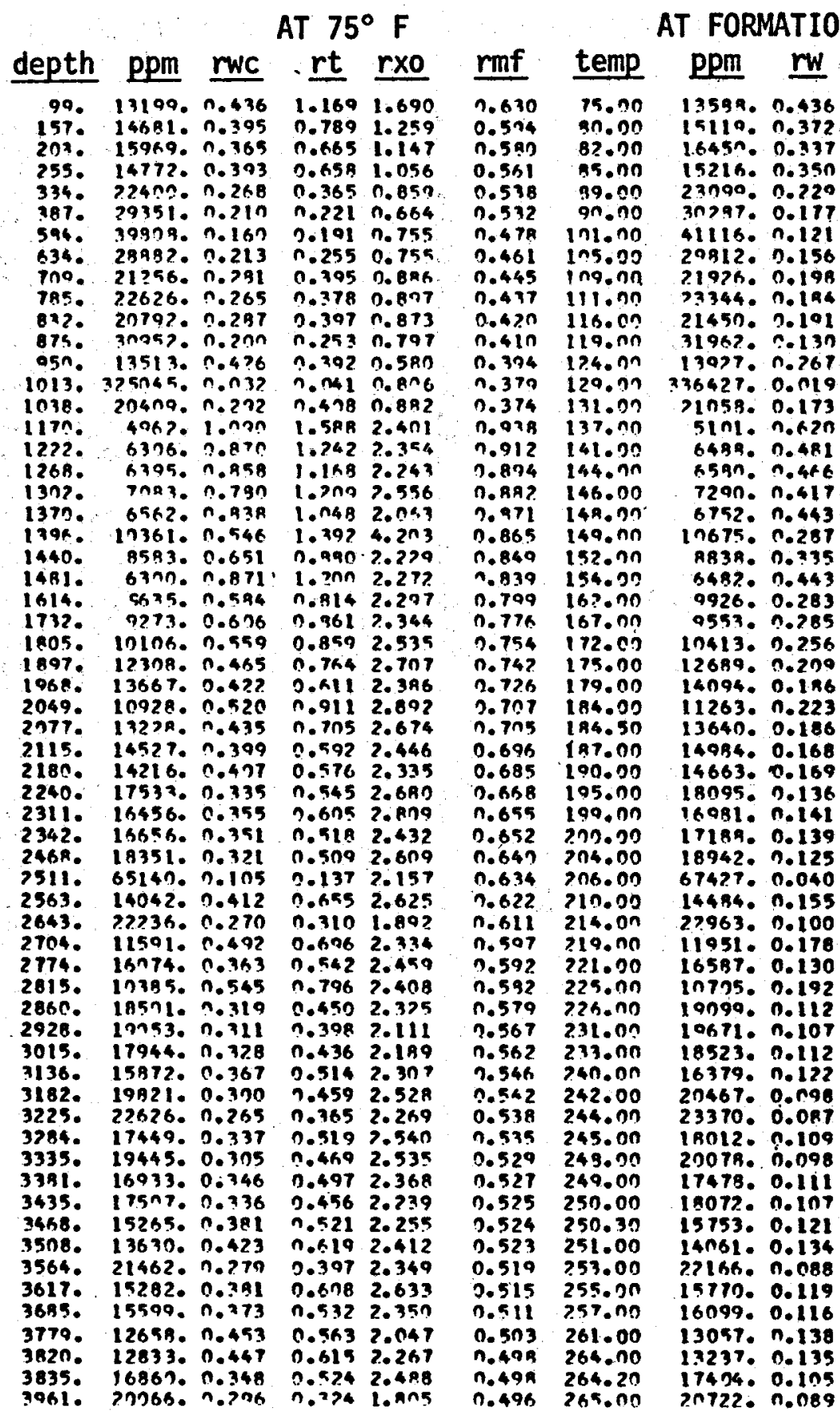


WELL LANDERS 1

\section{SALINITY CALCULATION FROM FLUSHED ZONE DATA}

AT $75^{\circ} \mathrm{F}$

depth Ppm rwc rt rxo

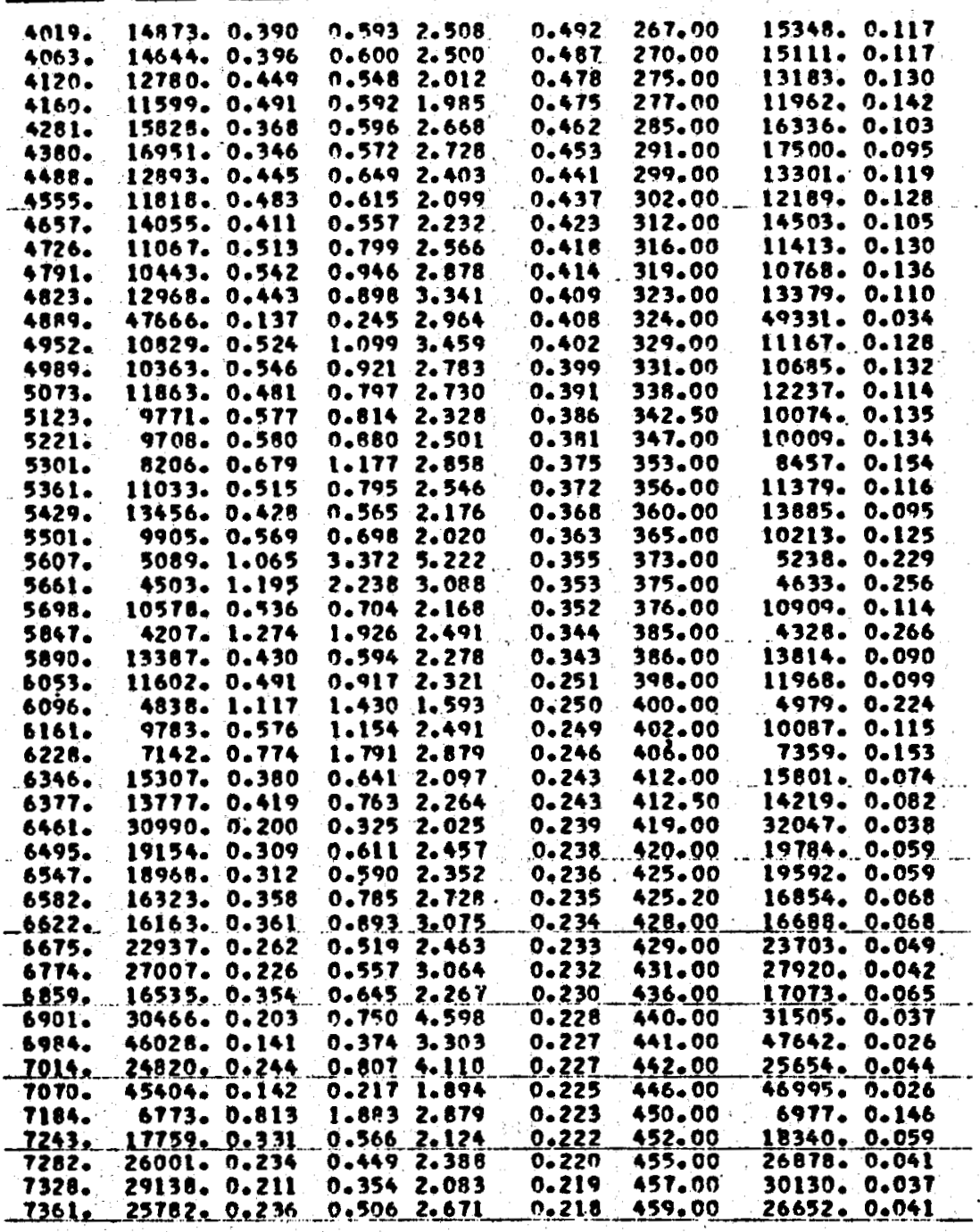

\section{AT FORMATION TEMPERATURE}

rmf temp ppm rw

D.

0.475277 .0011962 .0 .142

$0.462 \quad 285.00 \quad 16336.0 .103$

$0.453291 .00 \quad 17500.0 .095$

$0.441299 .00 \quad 13301 \cdot 0.119$

$0.437 \quad 302.00-12169.0 .126$

$0.418316 .00 \quad 11413.0 .130$

$0.414 .319 .00 \quad 10768.0 .136$

$0.409 \quad 323.00 \quad 13379,0.110$

49331.0 .036

1379.0 .116

885.0.095

0.125

5238.0 .229

$4328 \cdot 0.266$

11968.0 .090

4979.0 .224

10087.0 .115

5001.0 .074

14219.0 .082

$32047 \cdot 0.038$

19784.0 .059

6854.0 .068

6688.0.068

1505. 0.037

$26652 \cdot 0.041$ 
WELL LANDERS 2

\section{SALINITY FROM ARCHIES EQUATION}

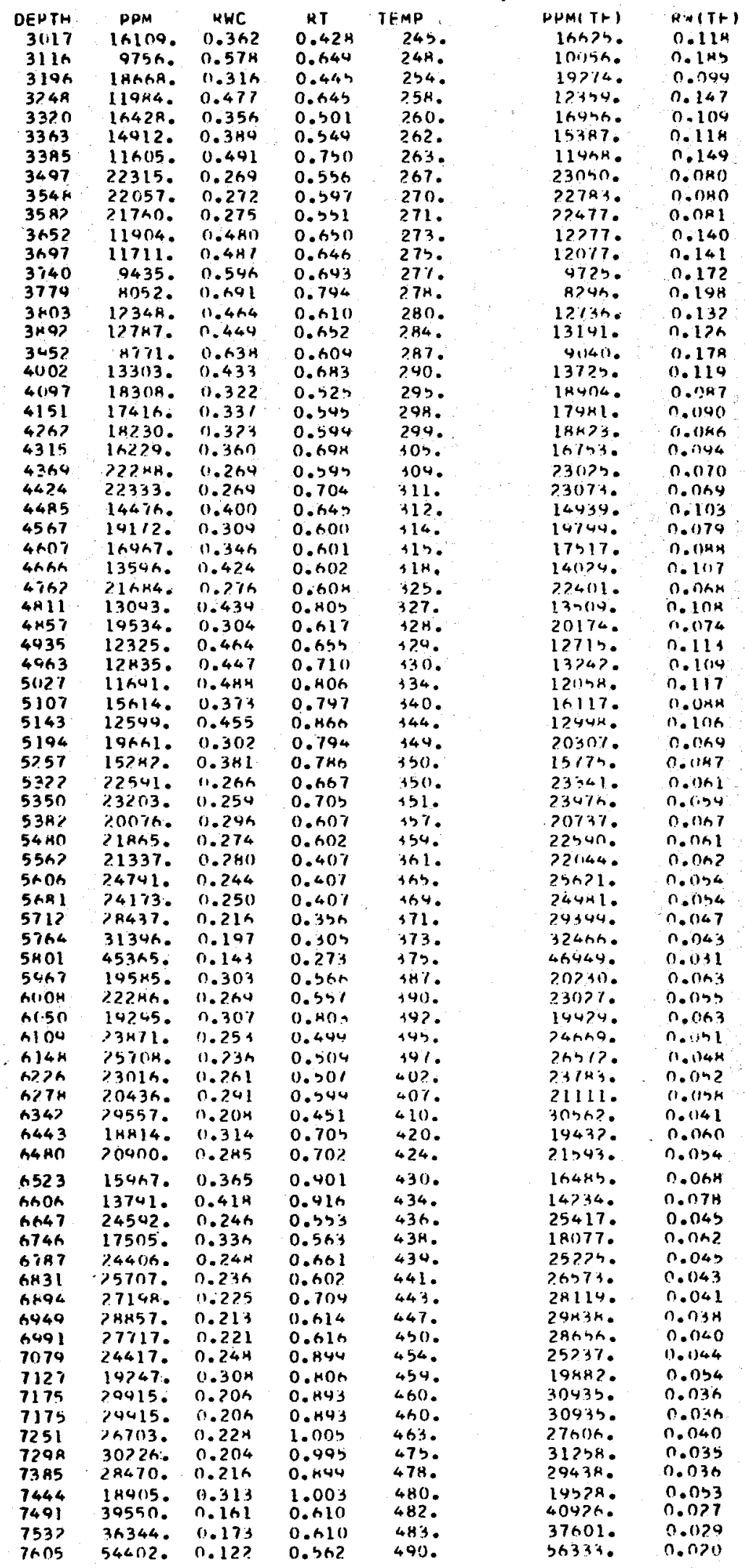


WELL LANDERS 2

\section{SALINITY CALCULATION FROM SP CURVE}

CORRECTED TO $75^{\circ} \mathrm{F} \quad$ AT FORMATION TEMPERATURE

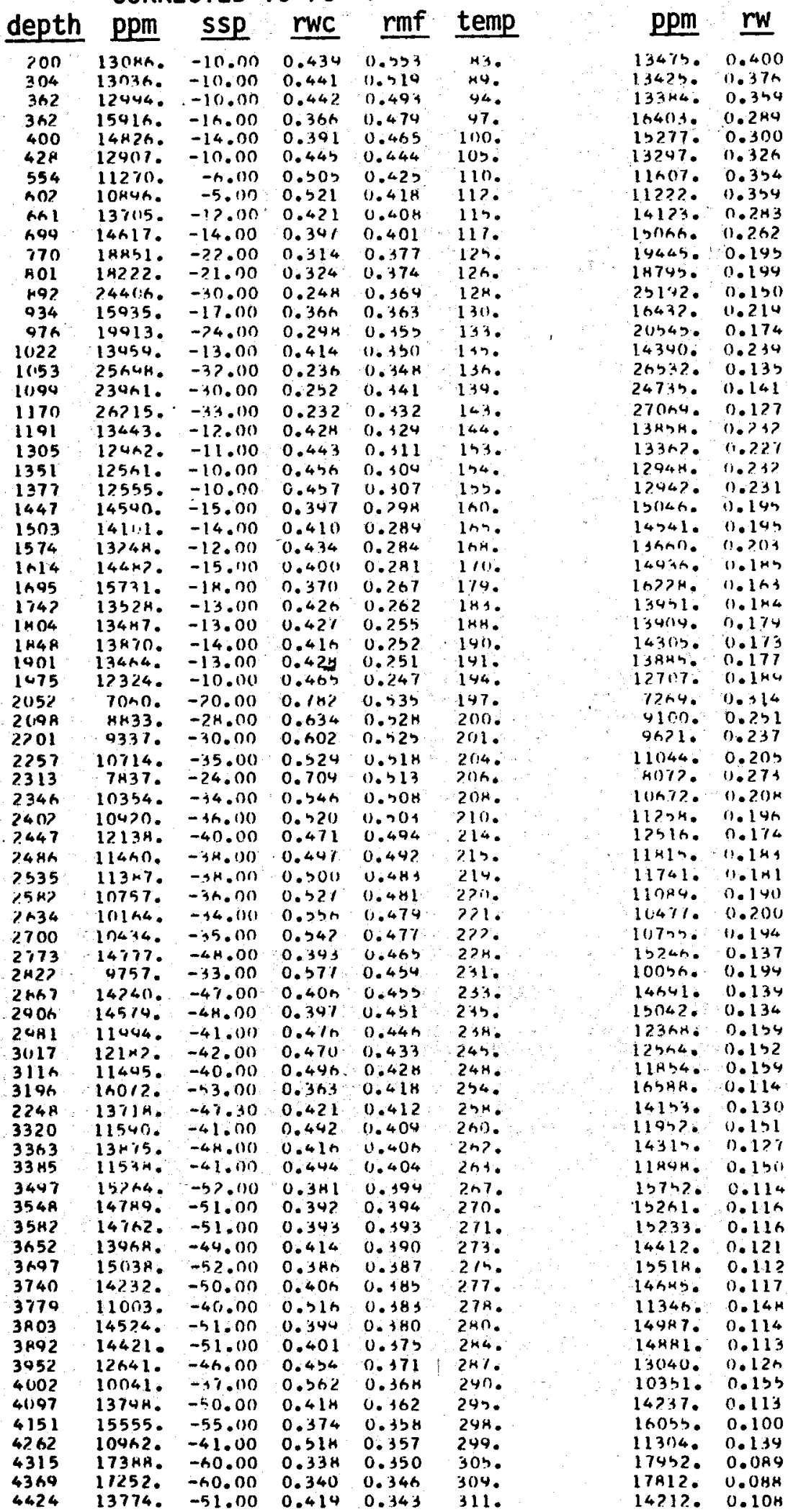


WELL LANDERS 2

SALINITY CALCULATION FROM SP CURVE CORRECTED TO $75^{\circ} \mathrm{F}$

depth ppm ssp rwC rmf temp

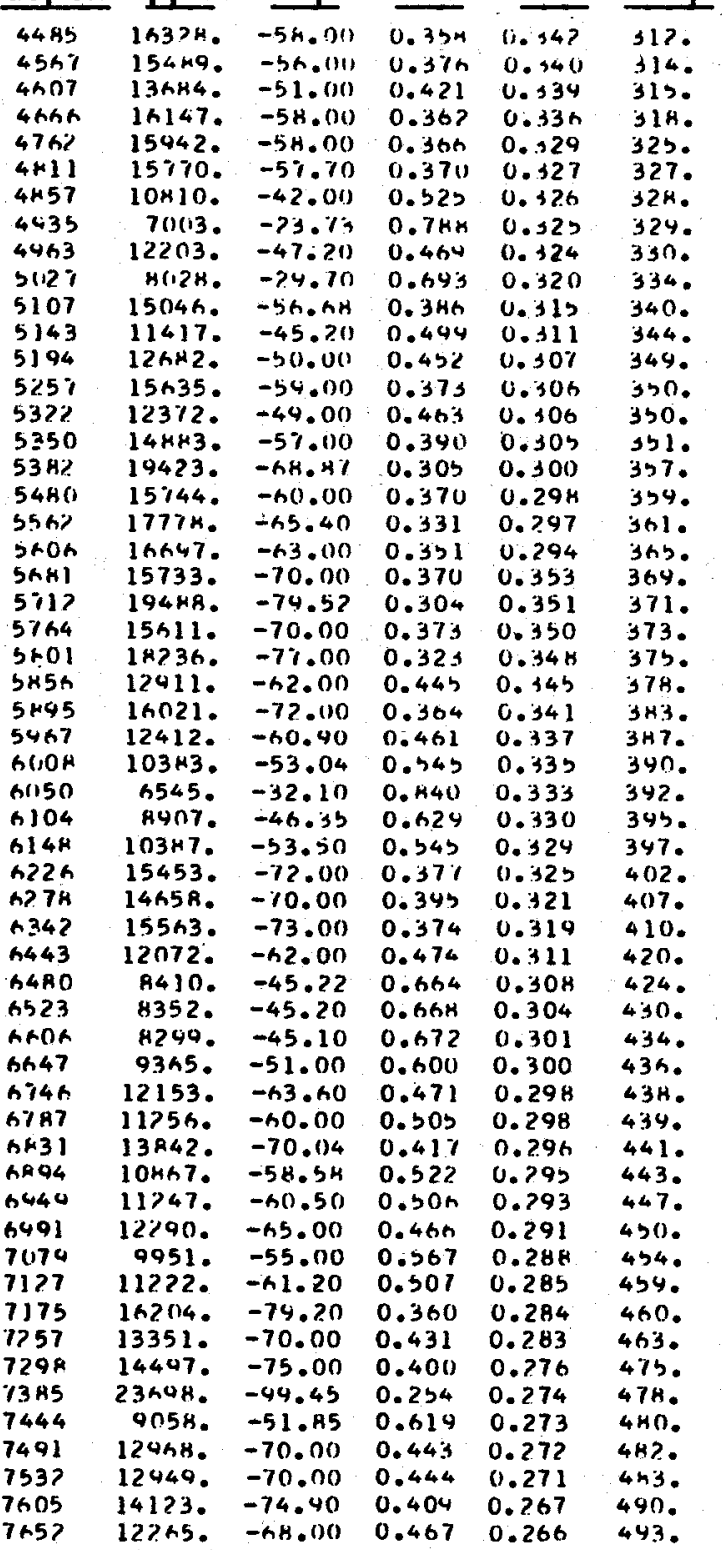

AT FORMATION TEMPERATURE

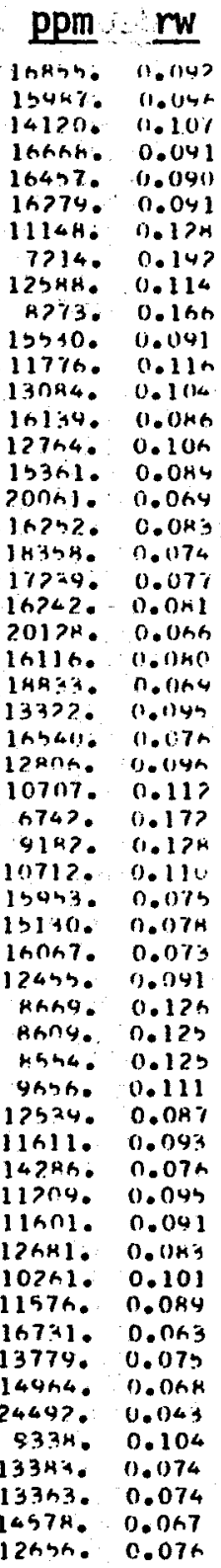




\section{WELL LANDERS 2}

\section{SALINITY CALCULATION FROM FLUSHED ZONE DATA}

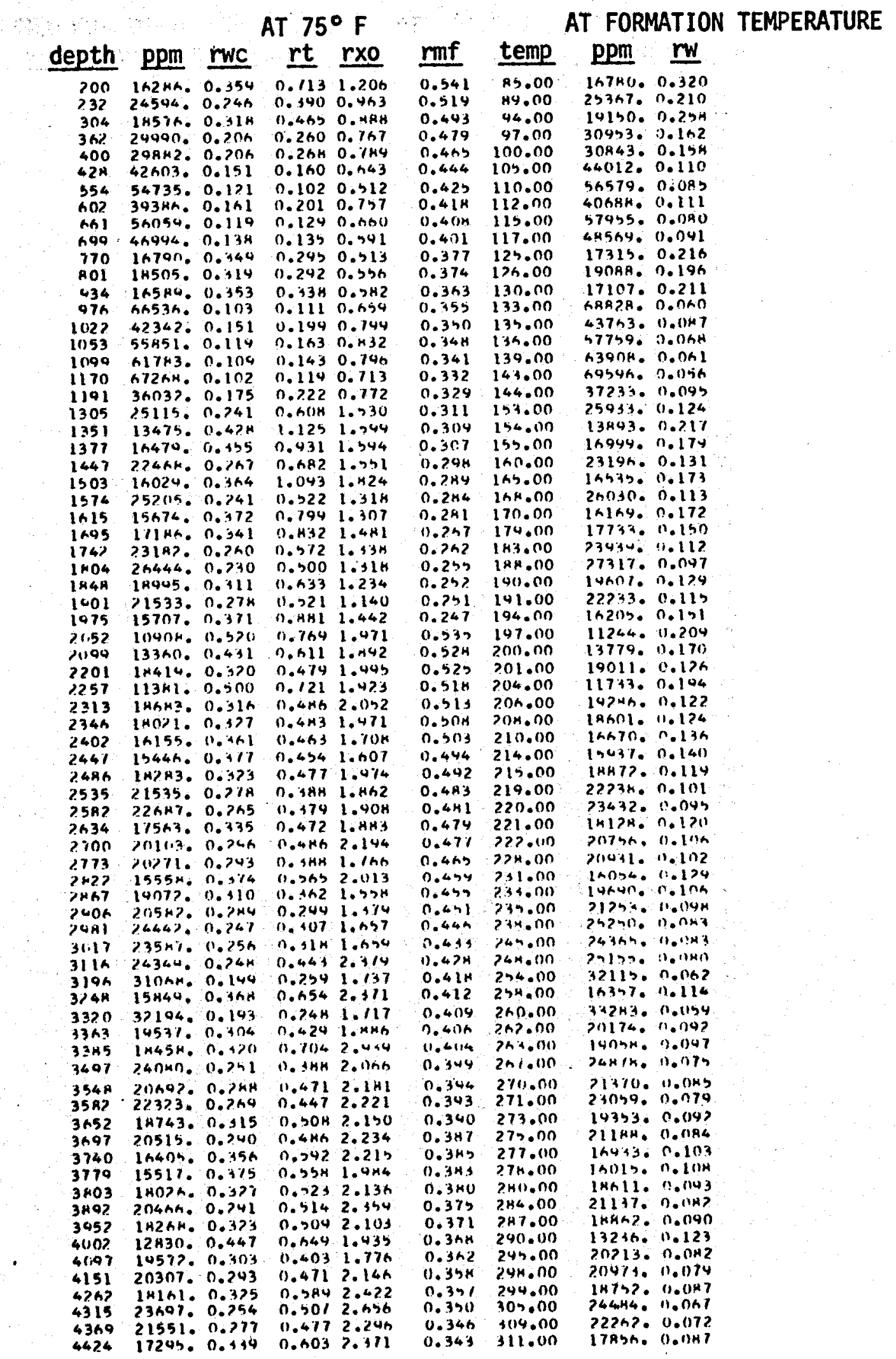


WELL LANDERS 2

\section{SALINITY CALCULATION FROM FLUSHED ZONE DATA}

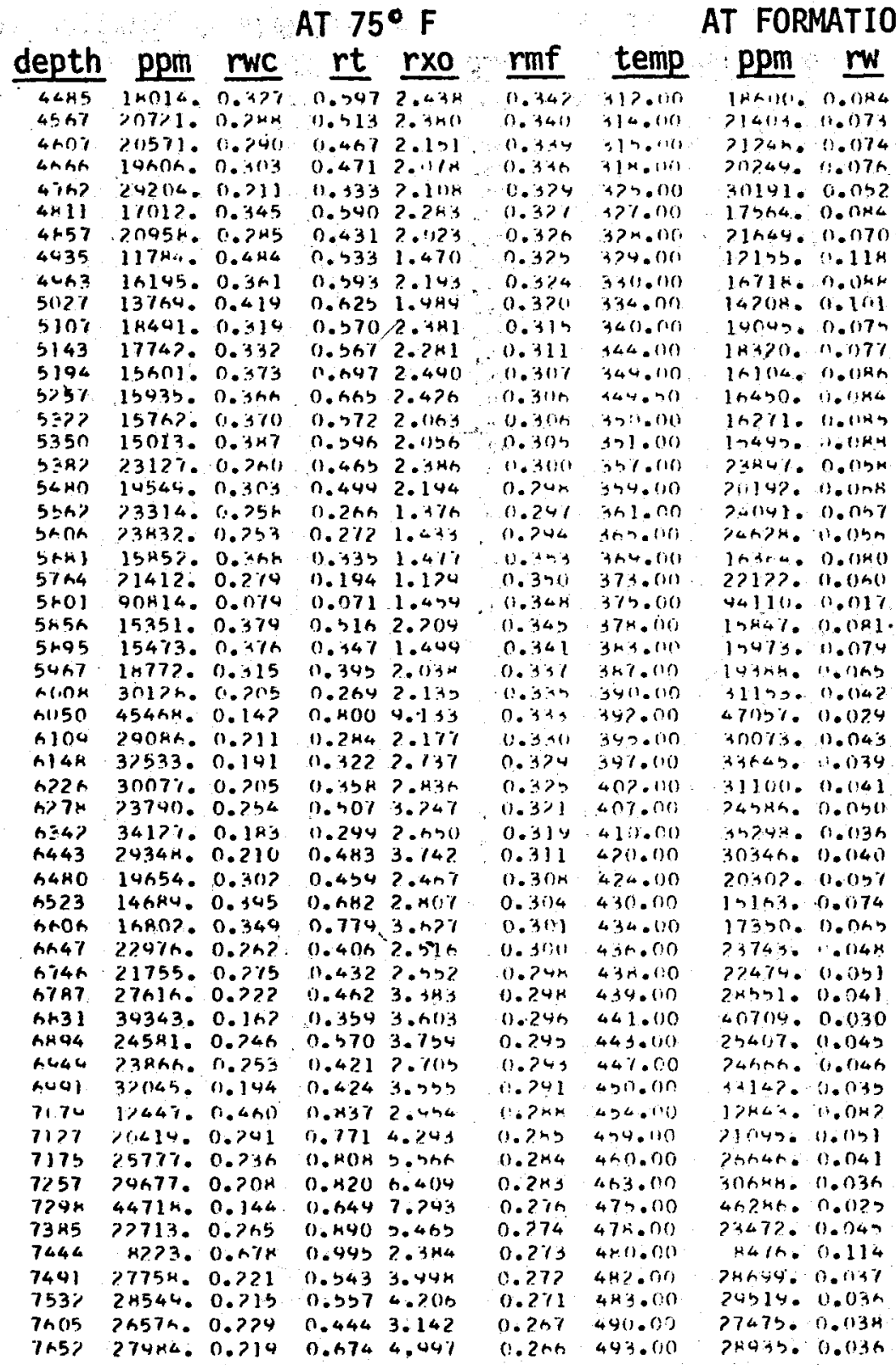


WELL DEARBORN FARMS 1

\section{SALINITY FROM ARCHIES EQUATION}

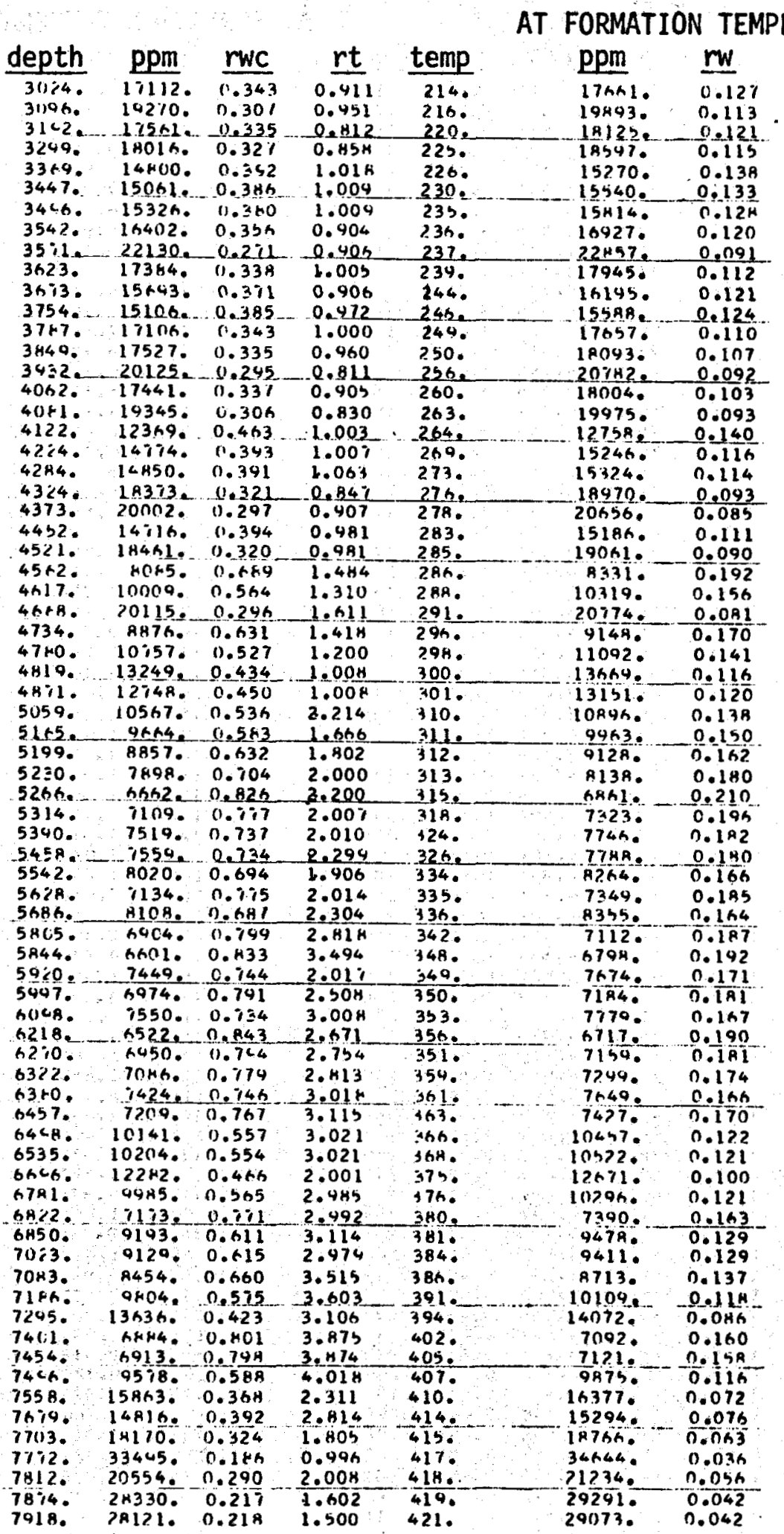


WELL DEARBORN FARMS 1

SALINITY CALCULATION FROM SP CURVE

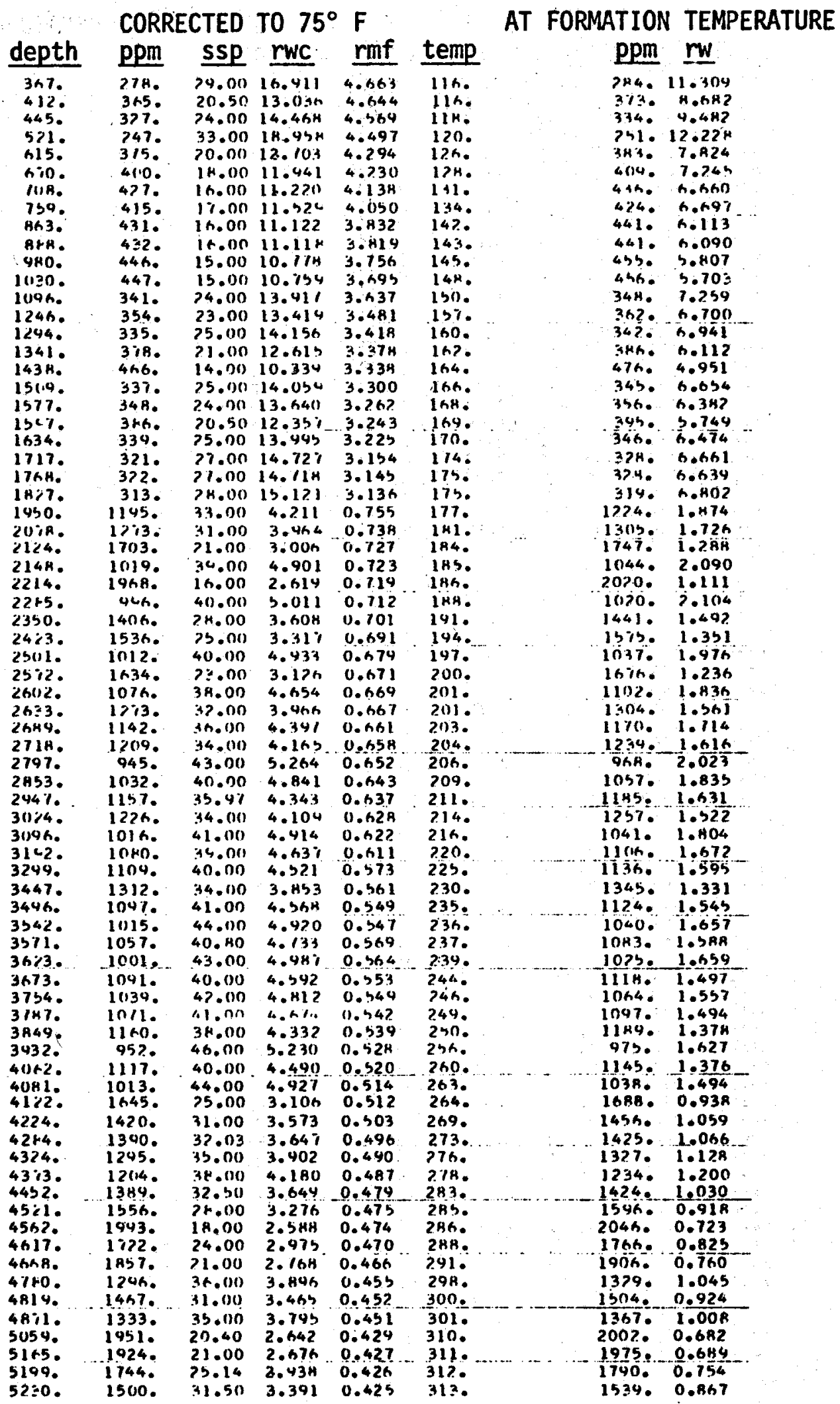


WELL DEARBORN FARMS 1

SALINITY CALCULATION FROM SP CURVE

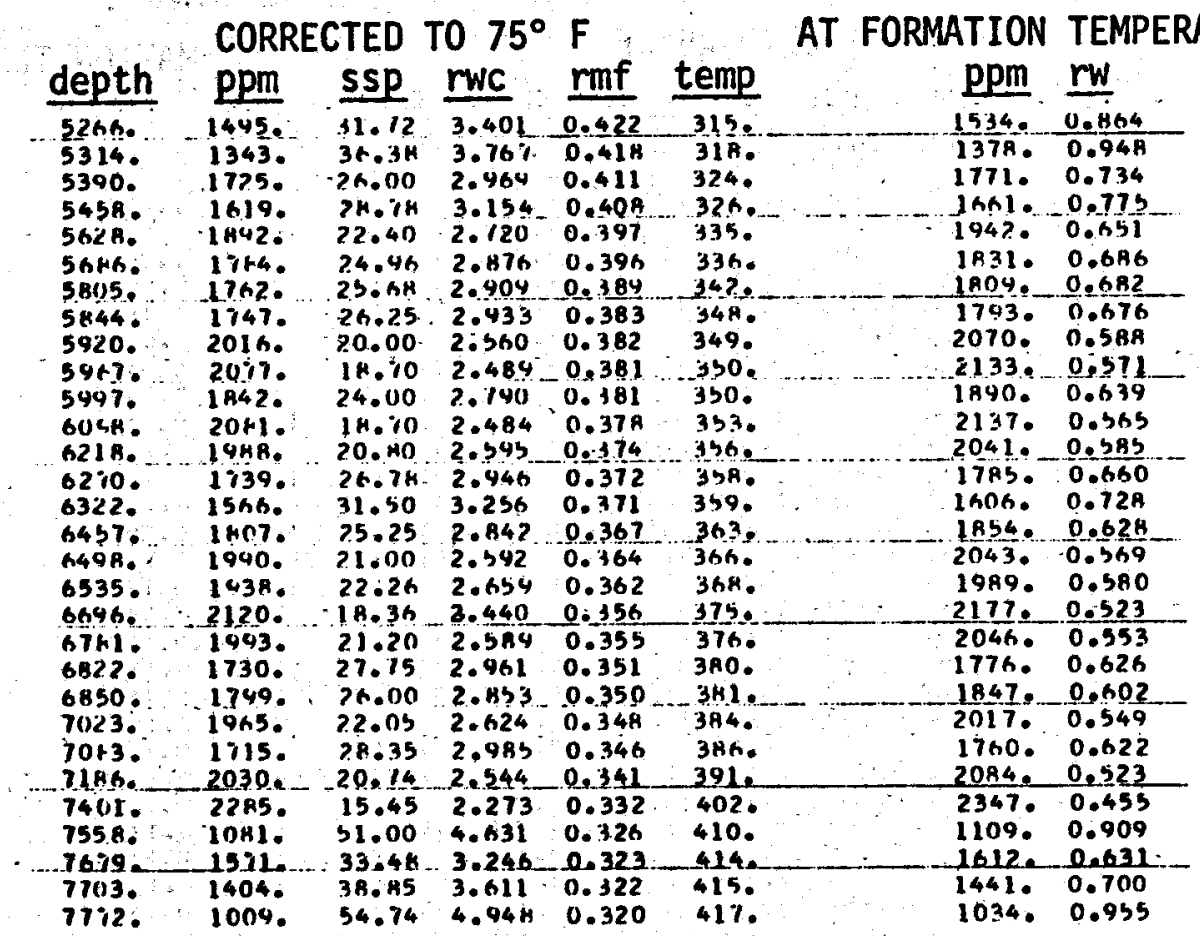


WELL DEARBORN FARMS 1

SALINITY CALCULATION FROM FLUSHED ZONE DATA

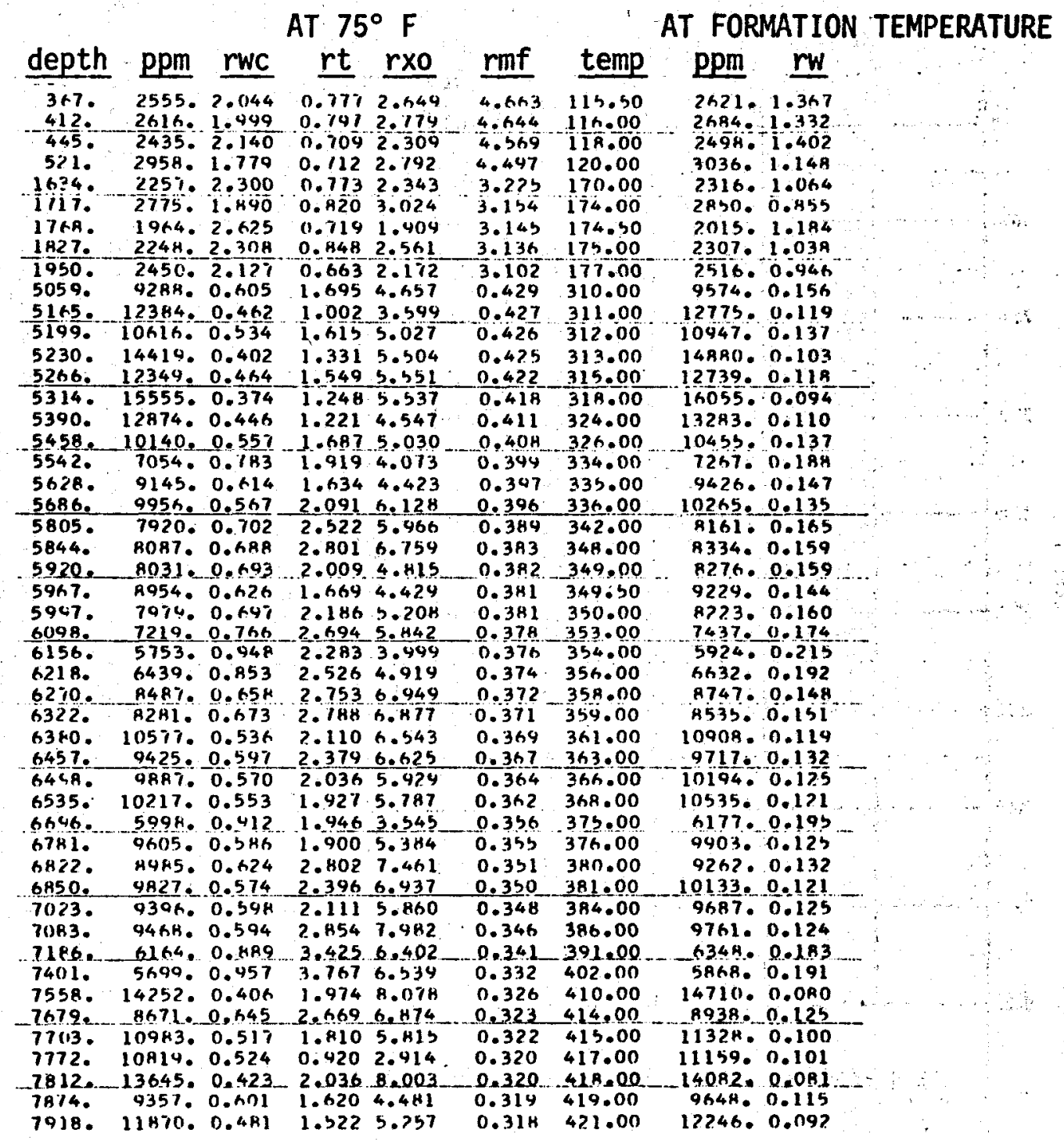




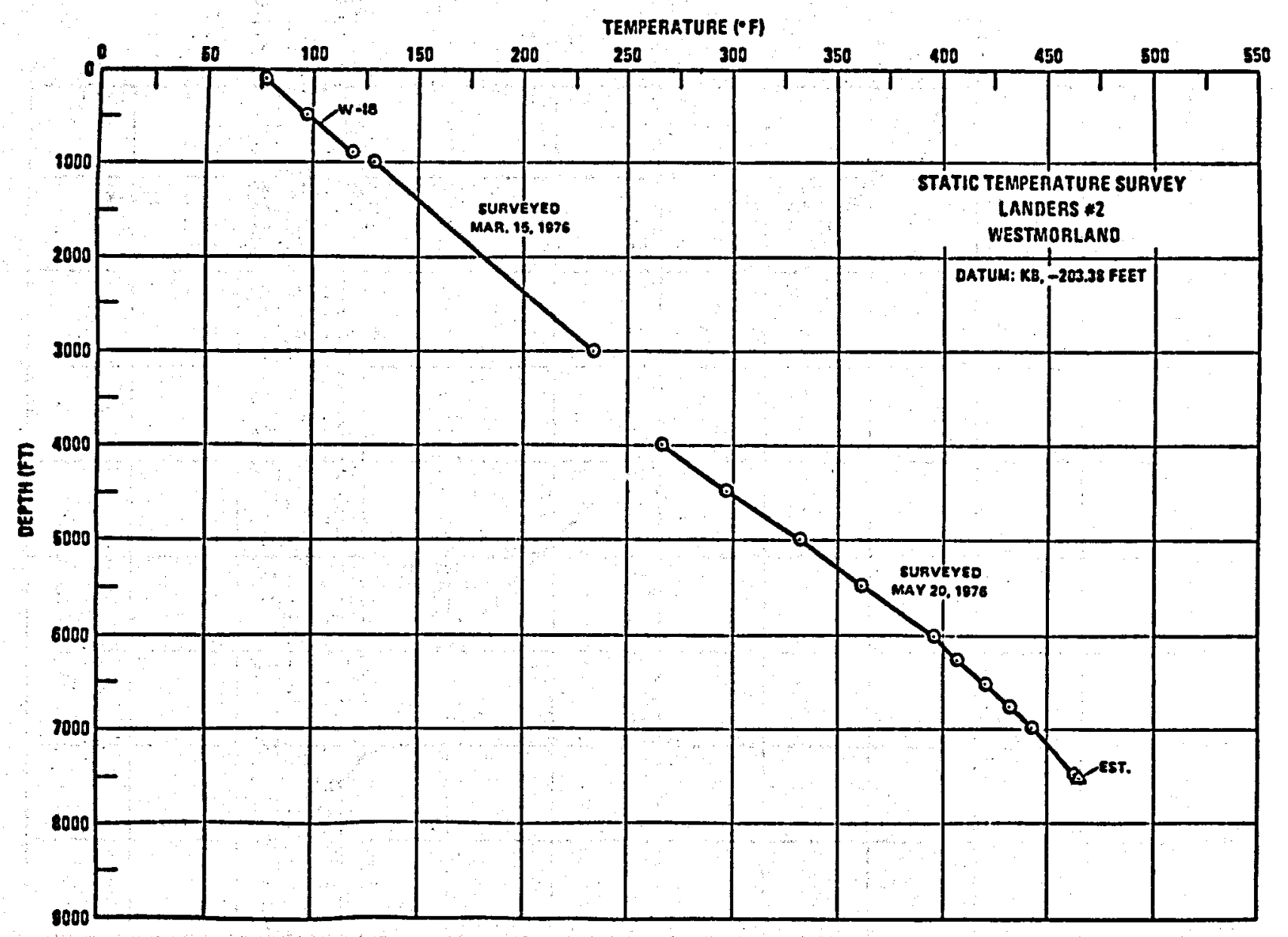

Temperature profile, Landers 2 (Republic Geothermal Inc., 1981). 


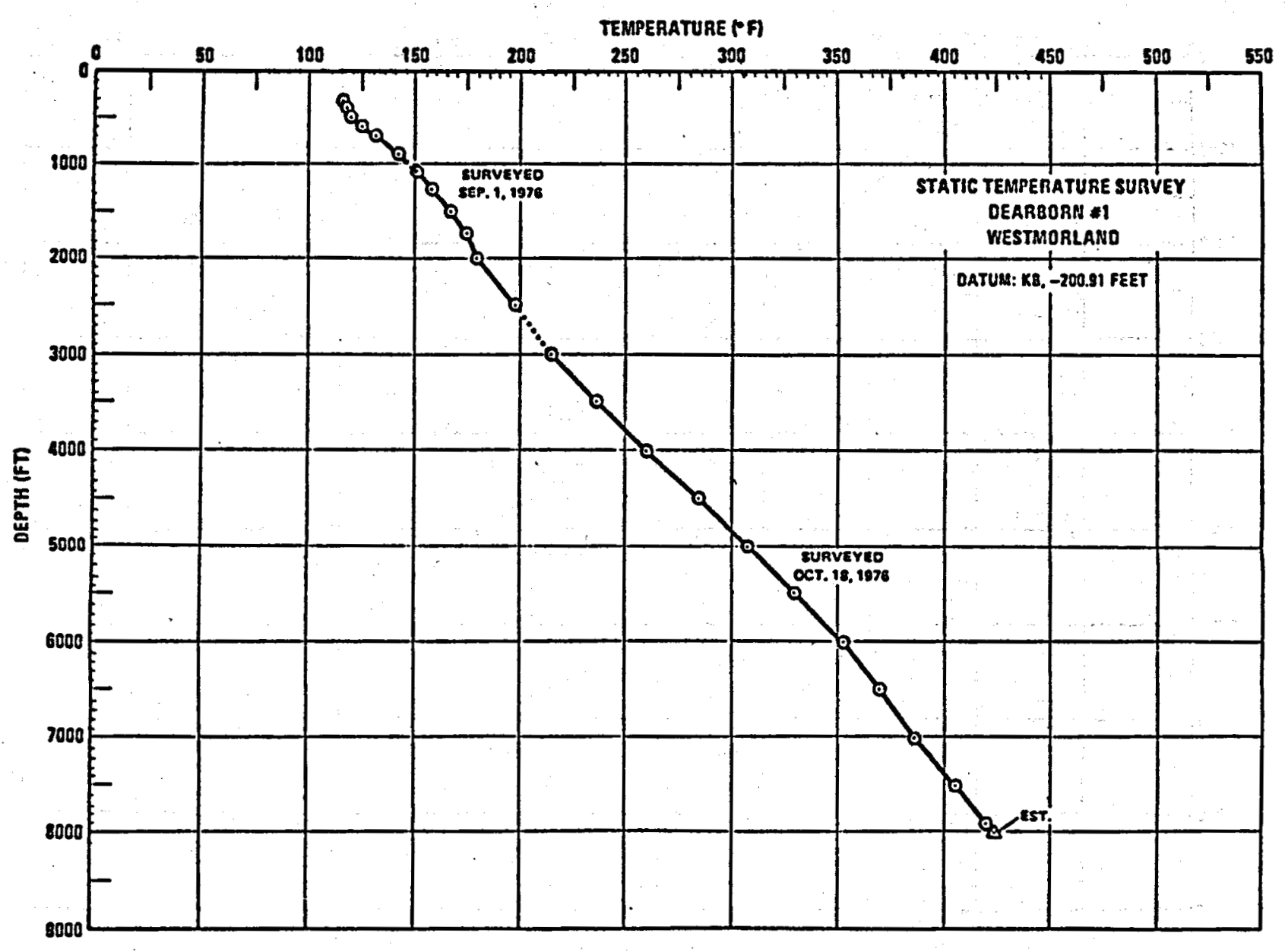

Temperature profile, Dearborn Farms 1 (Republic Geothermal Inc., 1981). 